Historic, Archive Document

Do not assume content reflects current scientific knowledge, policies, or practices. 



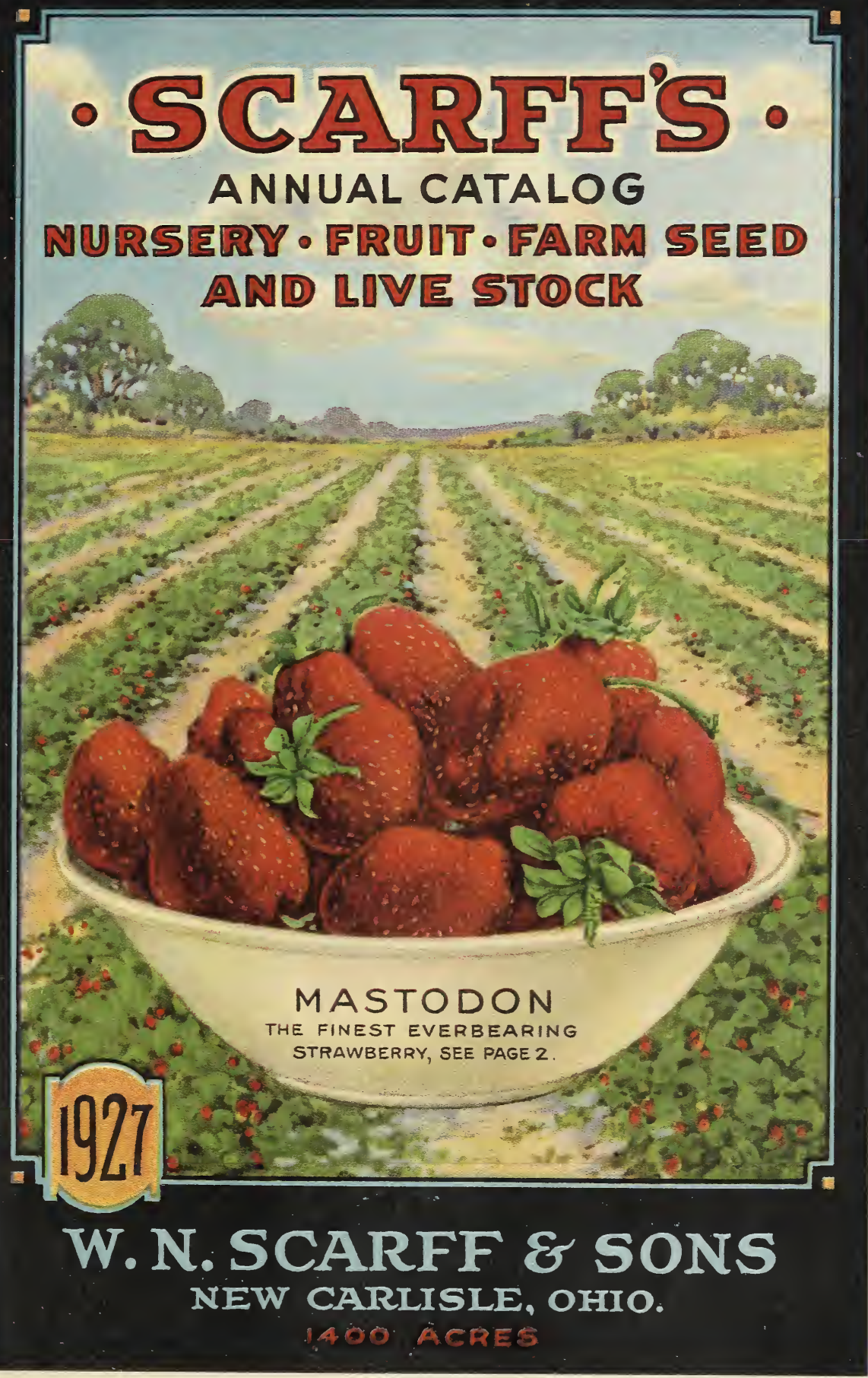


Oux Modern Seed Barm, 68×138 Feet, Fully Equipped with the Best Machinery.

Great Storing Capecity.

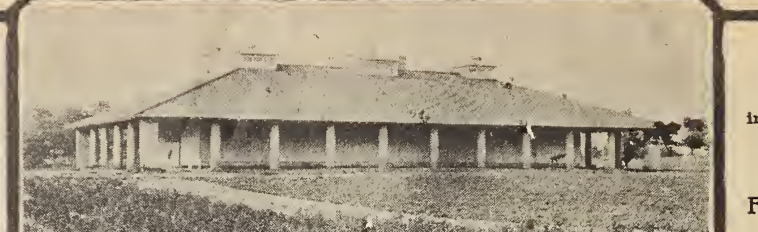

Largest of Its Kind in the State.

Located on the Farm.

No Agents. No Commissions to Pay.

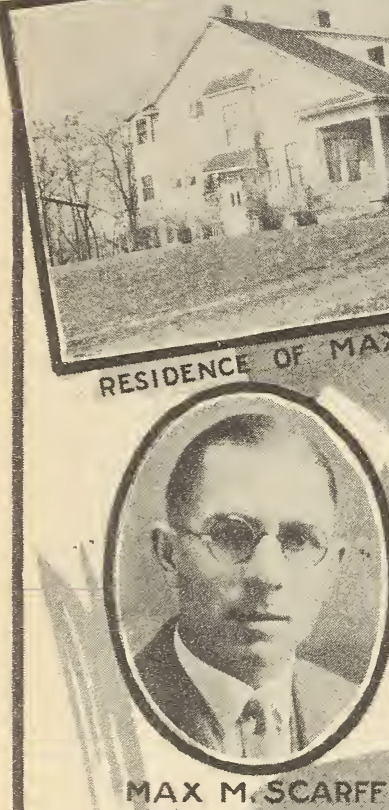

MAX MS SCARFE

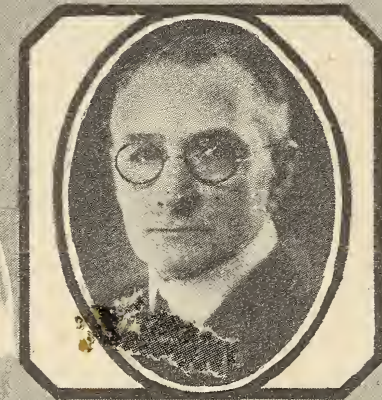

W.N. SCARFF

8

The Scartf Farms comprise more than 1400 acres in the heart of the fertile Miami Valley.

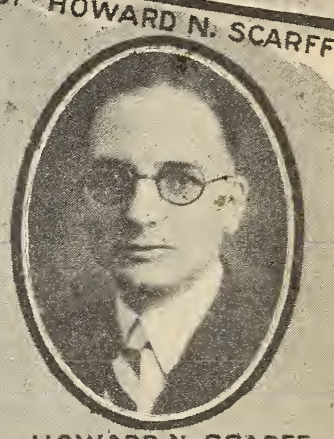

HOWARD N.SCARFF

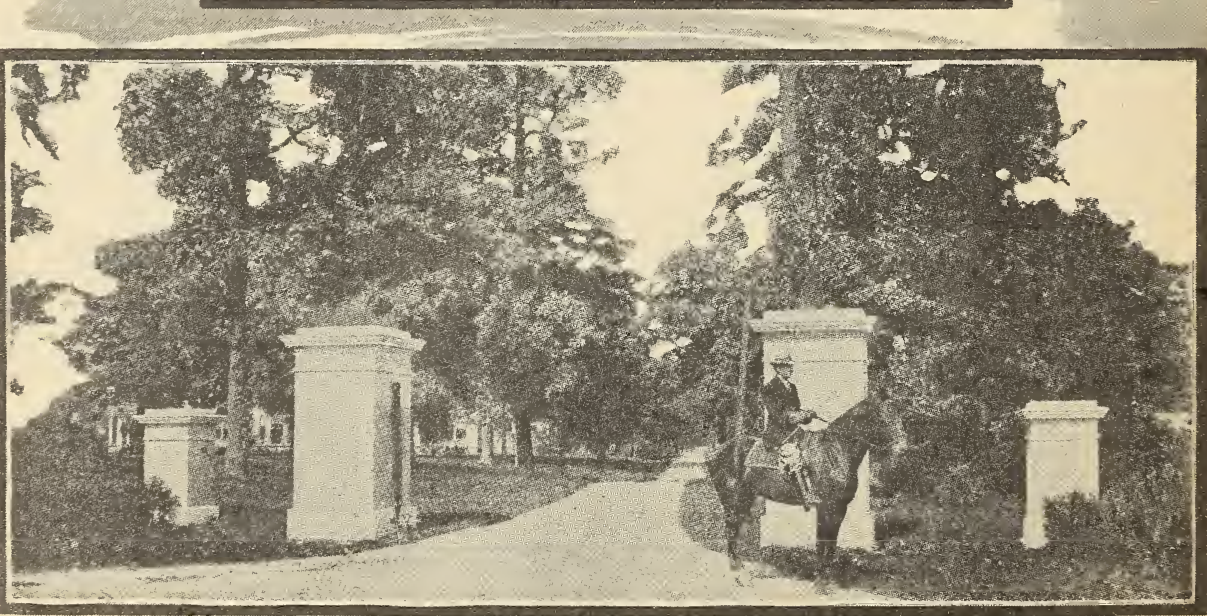




\section{Our Page of Greeting}

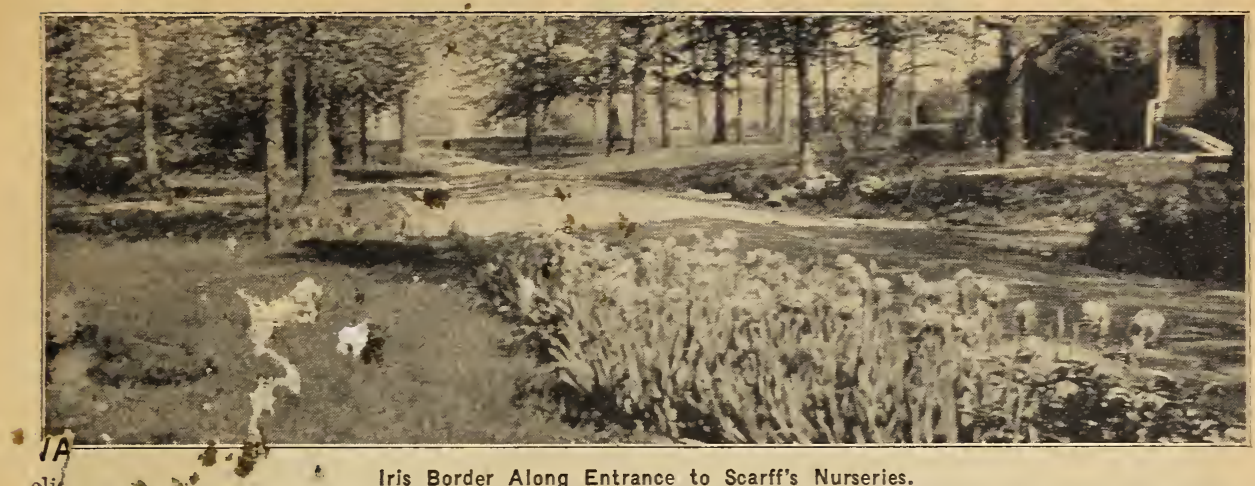

eli Iris Border Along Entrance to Scarff's Nurseries.

Catalog space is limited. In these few pages we have tried to tell you a few essential things about the items we are offering. However, this is one page that we have reserved that we might become better acquainted with you as our friends and customers. We know many of you personally but there are thousands of our customers who must depend on mail orders for securing the plants or seeds they want and this constitutes a large portion of our buigmess. We will give your order the same consideration if you send it by mail as we would if you came in pepsor to our Office.

On the opposite page we have shown pictures of the members of our concern and a few of the more familiar views on the farms. Mr. W. N. Scarff, originator of the business thirtv-five years ago, is still active as general supervisor. The Farms, Farm Seed and Live Stock Departments are in charge of Max Scarff; while the Horticultural Departments are under the supervision of Howard Scarff.

On our Farms and in our Orchards we have had ample opportunity to compare varieties under about the same conditions. Many. have been worthless and were discarded. The kinds that have proven their value to us are those we are offering to our customers, and we are glad that you may have the opportunity to beneflt from our experience.

This Catalog describes several new varieties that need more than average mention. First the New Mastodon Everbearing Strawberry, illustrated on the front cover page. Then the Latham Raspberry that is throwing new life into commercial Raspberry production. The Big Late Red Peach is gaining favor as a canning peach of par excellence especially in the central peach growing sections where hardiness is essential.

Striking new varieties of Ornamentals are not common, but this year a New Red Leaved Japanese Barberry is offered to the public for the first time. (See the illystrations in natural color on the back cover page). You will want to plant a few of these for contras

Farm Seeds. Most of our work with the farm seeds nat been to secure higher yielding strains and to select a better grade of clean high testing seed. We handle the best in all farm seeds and we will warrant that you will make no mistake in buying at Scarff's.

"ASK YOUR BANKER ABOUT US"

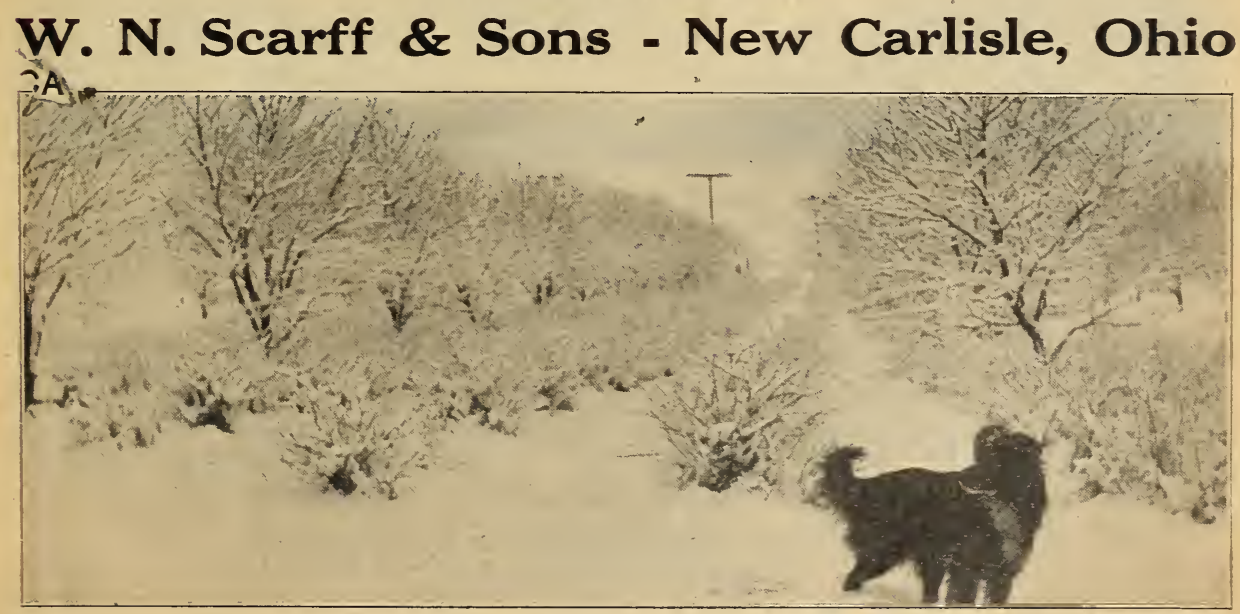

- Winter Scene In One of Our Orchards.

The above cherry orchard was interplanted with Currants and Gooseberries in 6 ft. rows and a row of Strawberries between each of these rows.

Small fruits are most valuable to plant in any young orchard. The cultivation that is necessary for the berries is just what the young trees require. 


\section{Mastodon}

\section{The Wonderful New Everbearing Strawberry}

Mastodon, the great strawberry found in Indiana a few years ago has stood the test in practically every section of the United States this season. It is now widely distrihuted and favorable reports come from experiment stations in various states where the berry has been tried.

In some places it is said this giant of the berry family produces three or four times as much fruit in a season as any four other varieties combined.

Here is a new giant everbearing that will start to produce an abundance of good fruit within three months after planting and continue to bear fruit until frost. The Mastodon has preven itself far superior to other everbearing varieties in many ways:

1. Fruit is almost double the size of the common everbearers.

2. Produces a heavy crop in the spring and another in late summer and early onll. other everbearers yield only a fair crop in the spring.

3. Plants are more thrifty.

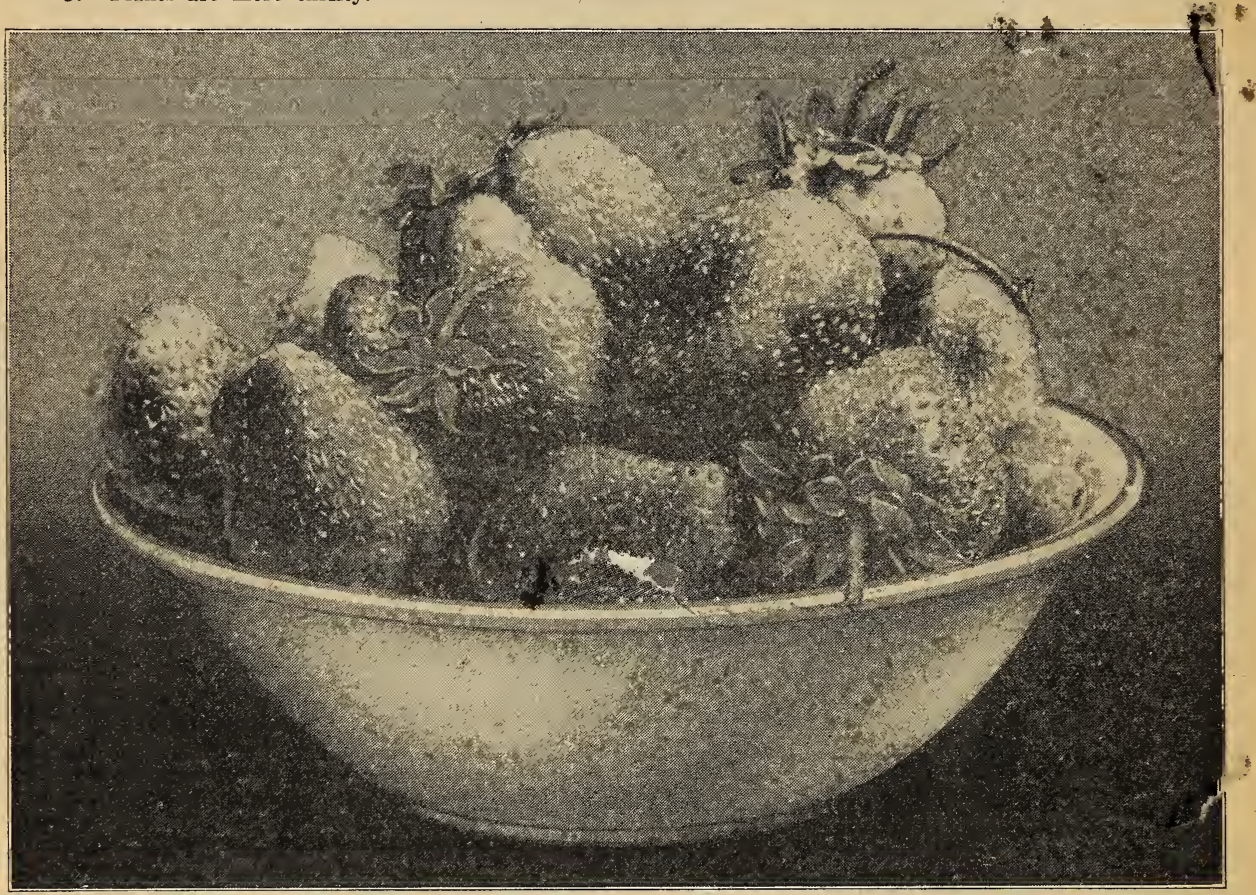

New Everbearing Mastodon Strawberries

Price New Everbearing Mastodon, 6 plants, 75c; 12 plants, $\$ 1.00 ; 25$ plants, $\$ 1.75 ; 50$ plants, $\$ 3.25$; 75 plants, $\$ 4.50 ; 100$ plants, $\$ 6.00$, postpaid.

\section{PROGRESSIVE}

\section{EVERBEARING STRAWBERRY}

This valuable Everbearing Strawberry is one of the best of its class. The plant closely resembles Dunlap, it is slender, long rooted and a very thrifty grower; foliage is ample, free from disease and a beautiful rich green. The berries of the Progressive are of excellent quality, delicious flavor and beautiful color. They can not be surpassed for home use, being equally delicious if eaten fresh or after canning. Many of our customers are growing Progressive for market, and they are making big money as the fruit sells readily at big prices. The fall-bearing strawberries have a fine flavor far surpassing that of the standard sorts. They are sweet, mellow and aromatic, a flavor you can enjoy from June until early winter frosts. Price, good plants, 75c per dozen, postpaid; $\$ 2.00$ per $100 ; \$ 15.00$ per 1000 , by express.

\section{CHAMPION}

\section{EVERBEARING STRAWBERRY}

The new Champion will produce a good crop the first season it is set. The next year it will produce an abundant spring crop followed by a continuous setting of fruit throughout the season. Commercial growers are planting the Champion as it is superior to the spring varieties in that it is a sure cropper. If the first set of bloom is killed by the frost, new blossoms will form and produce, a heavy setting of fruit; whereas, such a freeze to a spring variety means a total loss for the year.

Description. The Champion is a true everbearer, producing fruit on both the old and the new plants. It somewhat resembles the Progressive, but it is a much heavier cropper, stronger grower, better plant maker and the fruit is even of higher quality. After careful investigation, we strongly recommend the Champion for either commercial or garden planting. Price, $\$ 1.00$ per dozen, postpaid; $\$ 3.00$ per $100 ; \$ 20.00$ per 1000 . 


\section{Strawberries}

The large list of strawberry varieties is sometimes confusing to the prospective buyer. Some of them are verr profitable from a commercial standpoint; some more desirable for planting in the home garden because of their high quality. At the same time there are many varieties of only mediocre quality. We have carefully discarded this last-named class and are offering only those which have proven their worth.

\section{For the Home Garden}

It is always desirable to plant several varieties of different ripening dates so that you may have the fruit over a longer period of time. PREMIER (Per). First to ripen and one of the finest flavored varieties is the Premier, a berry of yielders, thus making the Premier one of the most desirable early varieties to plant. WARFIELD (Imp.) Following the Premier comes the Warfield. This is the variety most highly delicious flavor, medium size and are produced abundantly on the plant. It is one of the older varieties that has not lost any of its popularity. The Warfield is an imperfect bloomer and must be planted with some other variety, such as Dunlap or Gibson for pollination.

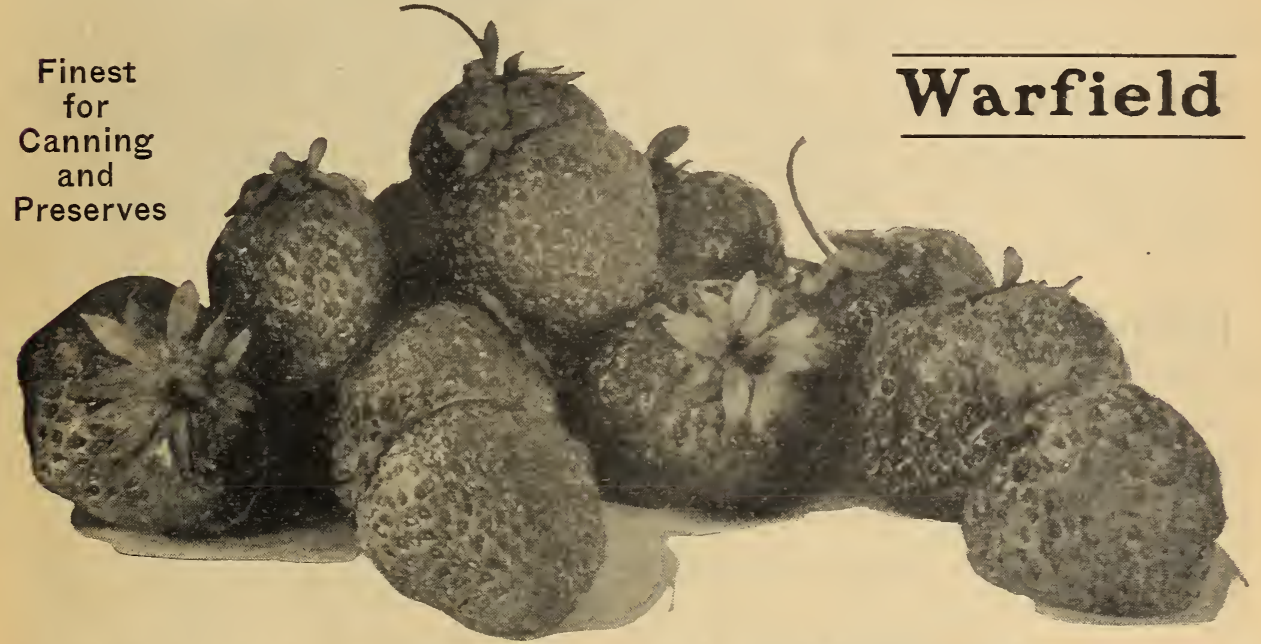

SCARFF'S SEEDLING (Per.) Last year this variety stood up under the severe drought and Were practically a filure. The vines a heavy crop of good size fruit when most other kinds Fruit large, delicious flavor and has proven an exceptionally good variety for the home garden.

POCOMOKE (Per.) The outstanding characteristics of the Pocomoke are hardy and productive firm, well colored and good quality.

CHESAPEAKE (Per.) As a late variety for quality and beauty the Chesapeake is unexcelled. It is family and if quality is considered, acknowledged to be one of the finest flavored berries of the strawberry ever, is but one of its good traits, for it is cne of the largest and most handsome varieties grown.

The fruit is uniformly large and well-shaped. It colors all over to a deep red so there are no green tips to disfigure it, and presents a very striking appearance that always brings a fancy price.

If you do not have this variety in your collection, we advise you to plant some of them at least, and you will be enthusiastic with the results. Our plants are pure, all from new beds and first-class in every respect.

Market gardeners plant their strawberries under irrigation and find it their most profitable crop. The sprinkling systems also act as frost protection in the spring, so the strawberry can always be depended on as a sure money crop for these growers.

\section{PRICES OF STRAWBERRY VARIETIES}

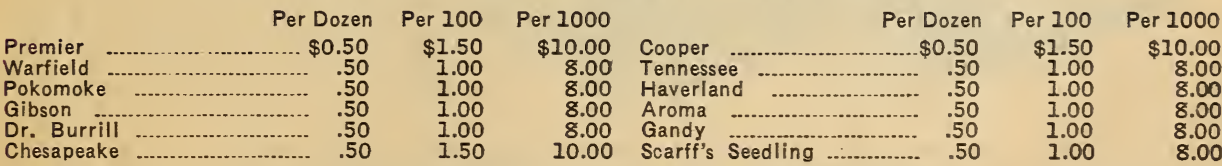




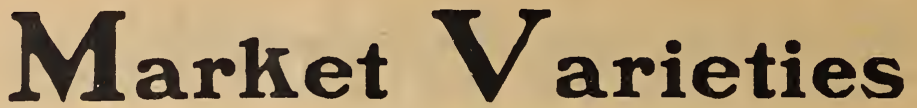

The following list includes those varieties which because of their reliability in both productiveness and plant growth can be depended upon to yield a good profit to the commercial grower.

\section{PREMIER}

(PER.) Previously recommended as a garden variety is a money-maker for market because of its extreme earliness. The fruits are delicious in qualty, large in size and hold their size well throughout their long bearing season. The commercial grower will find the Premier one of the most profitable kinds he can plant.

\section{COOPER}

(PER.) Following $\mathrm{t} \mathrm{h}$ e Premier in ripening, the Cooper is a remarkably new variety that promises to become a leader in the "Large Berried Class." The fruit is uniformly large, exceedingly sweet, ripening evenly without green tips or hollow core. Starts to ripen quite early and continues over a long period. Plants are exceptionally strong growers, making hills nearly as large as a bushel basket. The fine root system enables it to produce a good crop even in dry, hot seasons. You will be more than pleased with the heavy crop of large, fine-flavored berries produced by the Cooper. You should not fail to get a start of this wonderful new variety.

\section{DR. BURRILL (IMPROVED DUMLAP)

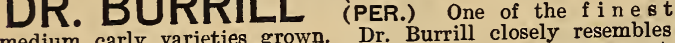
medium carly varieties grown. Dr. Burrill closely resembles Dunlap, which is conceded to be one of its parents. A strong, vigorous grower and a heavy yielder even under quite adverse conditions make this variety a valuable one for the
commercial grower or for in the home garden. You will commercial mistake in ordering Dr. Burrill. We are offering a fine lot of these plants that are strictly true to name.

TENE (PER.) This is another midTENNESSEE season variety that has given great satisfaction wherever planted. It resembles the Dunlap great satisfaction wherever planted. It reeper and somewhat in appearance except that it is larger, deeper and somewhat is a heavy yielder.

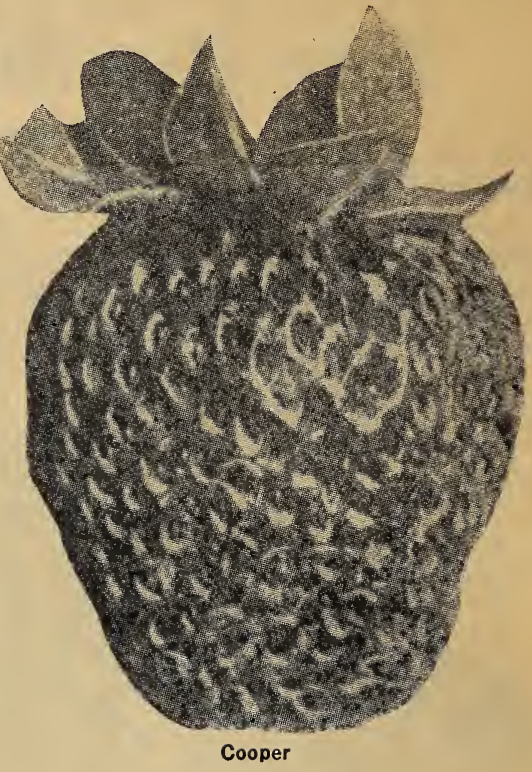

N N (IMP.) The Haverland is one of the older varieties that is still planted and HAVERLAND yields returns fully equal to most of the newer sorts. It is exceedingly productive and resistant to frost, bearing large crops when others are killed. No other will produce more fruit per tive and resistant to frost, bearing large crops when others are more money. The Haverland must be planted with some other variety for pollination.

A (PER.) Two varieties stand out preeminently as profitable for late season-Aroma, and AROMA (PER.) Two varieties stand out preeminently as profitable for ially for the Central and Southern Sections. It makes a fine plant growth and produces large handsome fruit of bright red color,

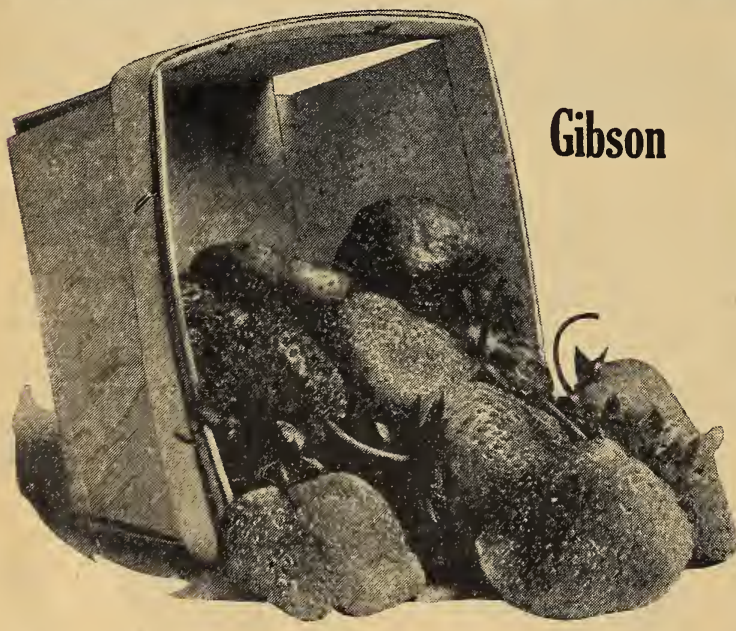
uniform, firm and good quality. A reliable variety and a heavy yielder.

GANDY (PER.) For the Central GANDY and Eastern Fruit Sections there is probably not a more profitable late variety than the Gandy, which is one of the most reliable large late varieties grown. It is one of the old standard varieties that you can depend upon. Outstanding qualities are handsome, deep red, firm fruit of very good quality. and very late season. Plants make a thrifty growth but require a moist heavy clay soil for best production.

GIBSON (PER.) Is sometimes "Standard of Excellence" both for commercial and home growing. Besides being a beautiful appearing fruit of large size and deep red color extending clear to the heart of the berry, it has gained its popularity largely because of its wide adaptability to soil and other conditions. It is a great plant producer and the vines are simply loaded with berries. The flavor is as fine as can be found anywhere, making it in demand for either table use or canning purposes. 


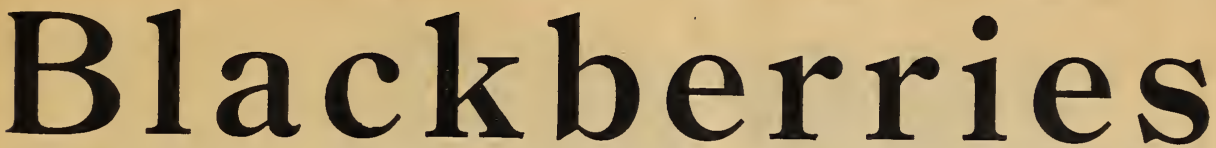

We excel in growing fine Blackberry plants. Our assortment is perhaps the largest of any grower in the United States. Our plants are mostly root cuttings, and as fine as can be grown. You make no mistake In ordering your Blackberries of us, as both our price and stock are right. Our plants will make you big money.

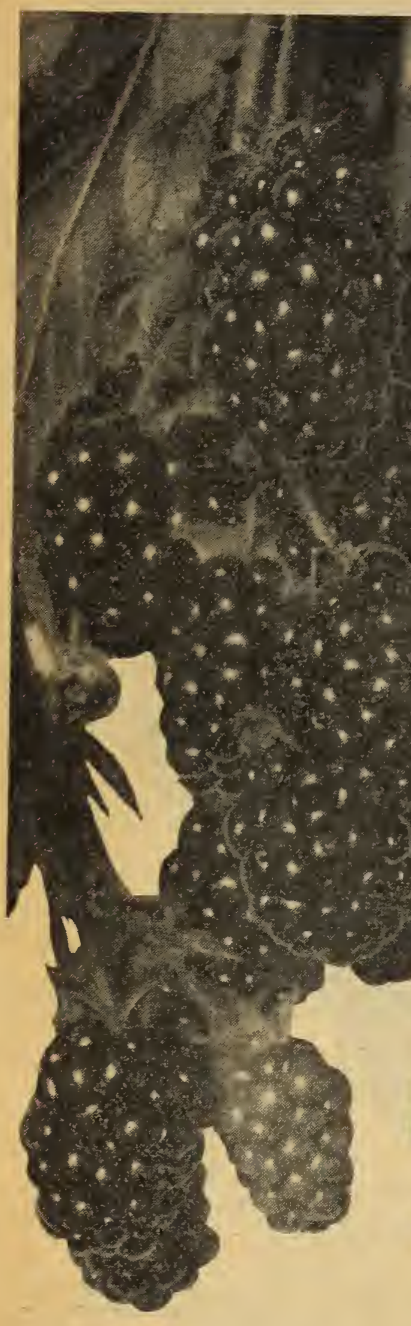

ELDORADO

ELDORADO This is one of the most $\nabla$ a luable varieties for market and home use. It is a strong, upright grower, moderately full of thorns. About equal in productiveness to Snyder. The fruit is jet black, never coloring red after picking; fully as large again as the average Snyder berry. The flavor is excellent, differing from all others in this respect, imparting a rich aroma, melting and juicy with but little core. Highly recommended by experiment stations and growers everywhere. It will sell for $50 \mathrm{c}$ to $\$ 1.00$ per bushel in advance of Snyder.

Eldorado is unquestionably one of the best commerical blackberries grown. The finest quality of the blackberry family. It is not a new variety, but one of the meritorious kinds that become more popular each year. Price, $15 \mathrm{c}$ each; $\$ 1.50$ per doz.; $\$ 4.00$ per 100 .

SNYDER One of the old favorites $t \mathrm{~h}$ at is still popular wherever Blackberries are grown. It is medium size, strong grower, hardy, and wonderfully prolific. It will $p$ e $r \mathrm{ha} p \mathrm{~s}$ make more bushels per acre than any other variety grown. It should be included in every commercial collection. Price, $15 \mathrm{c}$ each; $\$ 1.00$ per doz.; $\$ 4.00$ per 100 .

EARLY KING An extra exceedingly $\mathrm{h}$ a $\mathrm{rdy}$ variety of merit. Canes of strong growth. as hardy as Snyder, and very prolific. It is larger than Early Harvest. and its delicious sweetness renders it of special value for the home garden. It is also free of double blossoms, rust or other disease. It has been thoroughly tested in the North, and has given very general satisfaction. Highly recommended by the experiment stations. Growers coin money on this variety on account of its hardiness, large size and earliness. The only large early berry grown. Many dealers send out Early Harvest plants for this variety as the genuine stock is very scarce. Our plants are fine and true to name. Be sure to add it to your collection. Price, 20c each; $\$ 1.50$ per doz.; $\$ 5.00$ per 100 .

MERSEREAU This early mammoth, ironclad Blackberry is by far the most valuable variety that has appeared since the advent of Wilson, over 30 years ago. It originated in Northwestern New York, where the mercury falls from 15 to 25 degrees below zero, and where it has stood in open field culture for many years without the slightest protection, never being injured in the least. In quality, it is exceptionally sweet, rich, melting and luscious, being without core. The canes are of exceedingly strong, upright habit, attaining upon fairly good soil a height of 8 feet, if permitted to grow unchecked, and are so stout as to always remain erect; foliage large, deep green, abundant and entirely free from blight or rust. Its season is early in midseason, ripening with the Snyder-in advance of Kittatinny, Lawton, Taylor's Prolific, Erie, but not so early as the Early Harvest or the Wilson. A standard variety; one of the best. Price, 20c each; $\$ 1.50$ per doz.; $\$ 5.00$
per 100; $\$ 40.00$ per 1000 .

JOY Fruit of the Joy ripens about midseason; coal black in color and nearly as thick as long. Flavor is very rich and delicious. It is a good, strong grower, hardy and productive. You will surely want
to try some plants of this fine variety. Price, $20 \mathrm{c}$ each; $\$ 1.00$ per dozen; $\$ 4.00$ per 100 . 


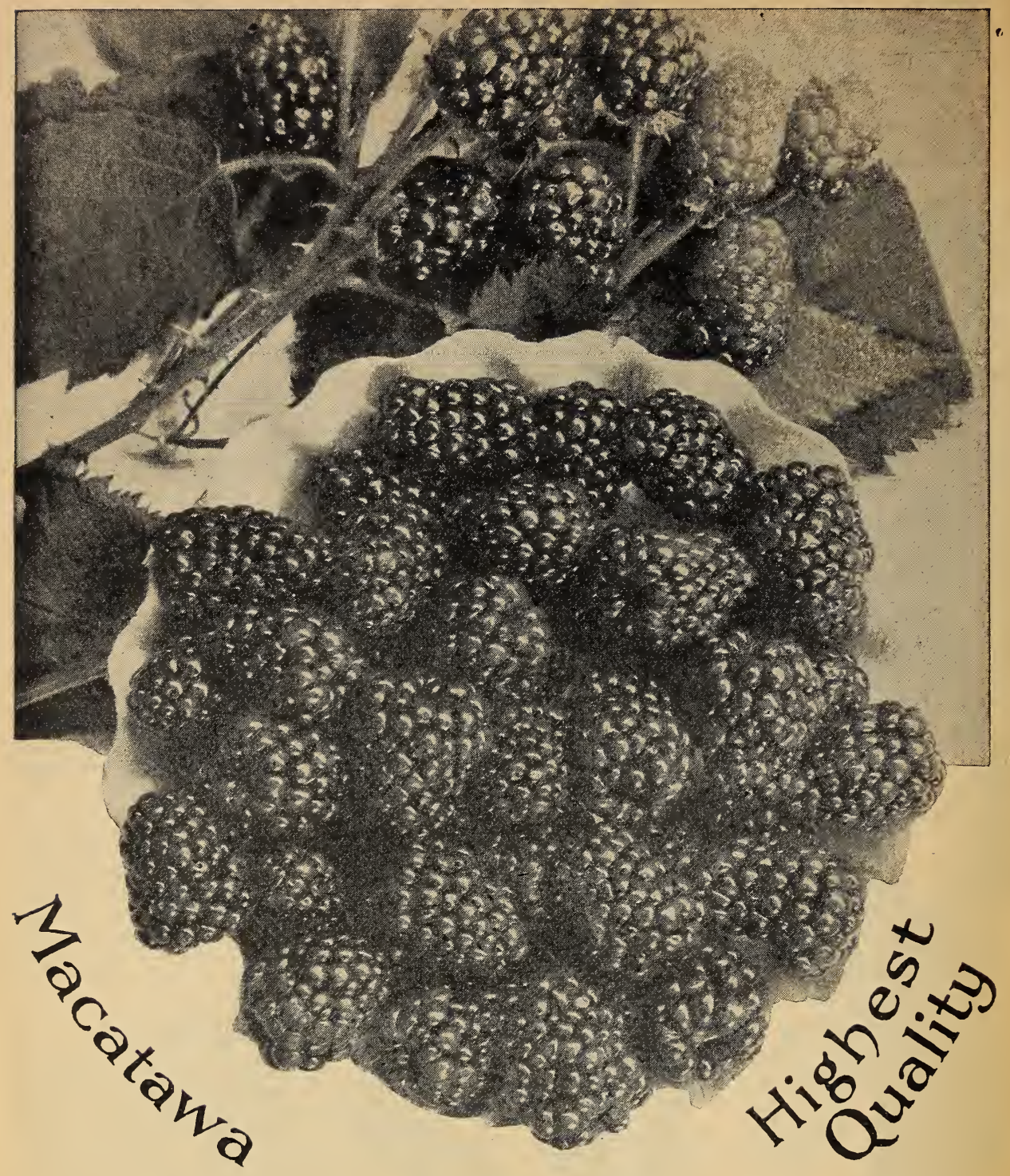

MACATAWA Plant this variety for highest quality and productiveness. The large jet black flavor and extreme productiveness of the Macatawa have made it one of our most profitable varieties. The canes are strong, upright growers, hardy and very prolific. The fruit is produced over a very long season, making it an especially valuable variety for home use or local market. Price, 20c each; $\$ 2.00$ per doz.; $\$ 6.00$ per $100 ; \$ 50.00$ per 1000 .

RATHBURN The berries are large-larger than Kittatinny, of an intense jet black, very glossy, ity, with a peculiarly fine aroma, and sufficiently firm to carry well to market. It is in habit of plant, however, that this variety differs from others. The plant suckers very little; it makes a strong, upright stem, from which the branches start out long and drooping, and the ends of which root readily in the ground, like Black Cap Berries, if covered lightly with soil. It forms a compact bush of four to five feet high, with canes much less thorny than other varieties, and yields abundantly. It ripens early -about with Wilson. Price, 15c each; $\$ 1.50$ per doz.; $\$ 5.00$ per $100 ; \$ 40.00$ per 1000 . 


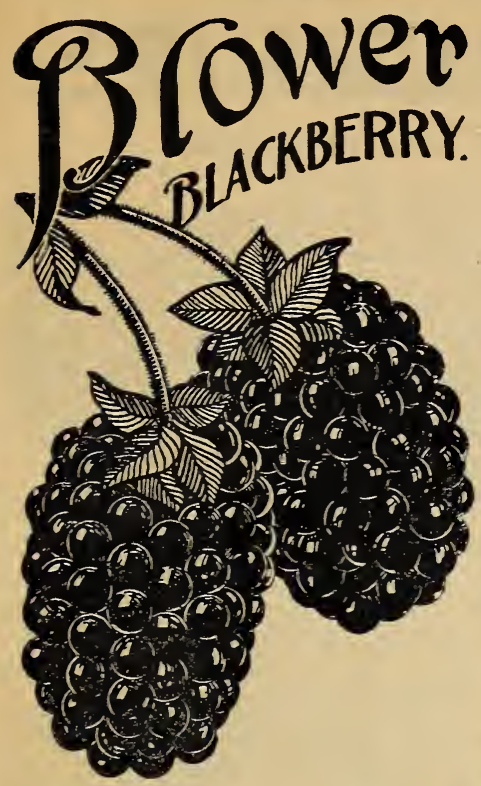

\section{B L O W E R}

The Blower has been an outstanding favorite among fruit growers for several years. It is deserving of this high esteem for several reasons, namely: It produces very large fruit almost the size of Dewberries; berries are jet black color and delicious flavor; Blower is one of the most productive varieties in cultivation, begins ripening in July and continues until September. It alweys sells for highest market price. If you do not have this valuable variety we hope you will try it. This variety is very popular among New York growers. It is claimed that 27 Blower berries filled a quart box and the yield was fully 50 per cent larger than any other variety. Price, 20c each; $\$ 2.00$ per dozen, postpaid; $\$ 6.00$ per $100 ; \$ 50.00$ per 1000 .

\section{EARLY HARVEST}

150 bushels of "Scarff's Fruiting Strain Early Harvest" from one acre sold as high as $\$ 4.00$ per bushel. The earliest to ripen and the most productive of the early sorts. There are a number of different strains of Early Harvest Blackberries, all alike in appearance of wood and growth, but vastly different in productiveness. We noticed this peculiarity soon after its introduction, and have, by careful system of selection, selected a strain that is simply marvelous for great yields of luscious fruit. We have not only increased the productiveness, but size as well, and now have an early variety that cannot be excelled, as it ripens so early that it always sells at enormous prices. Price, Scarff's Fruiting Strain Early Harvest, 20c each; $\$ 1.00$ per doz.; $\$ 4.00$ per 100; $\$ 30.00$ per 1000 .

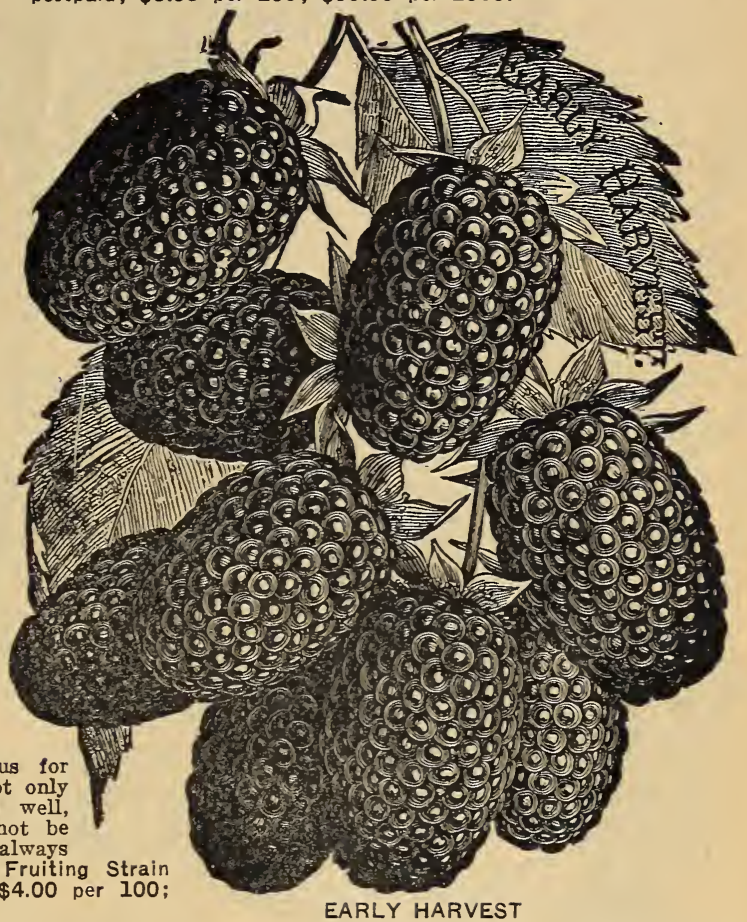
DEWBERRIES $\begin{aligned} & \text { We are just beginning to realize the great value of Dewberries. Plant } \\ & \text { them for profit. Plant them for home use. Their large size, sweet, delicious }\end{aligned}$ flavor and fineness of texture are

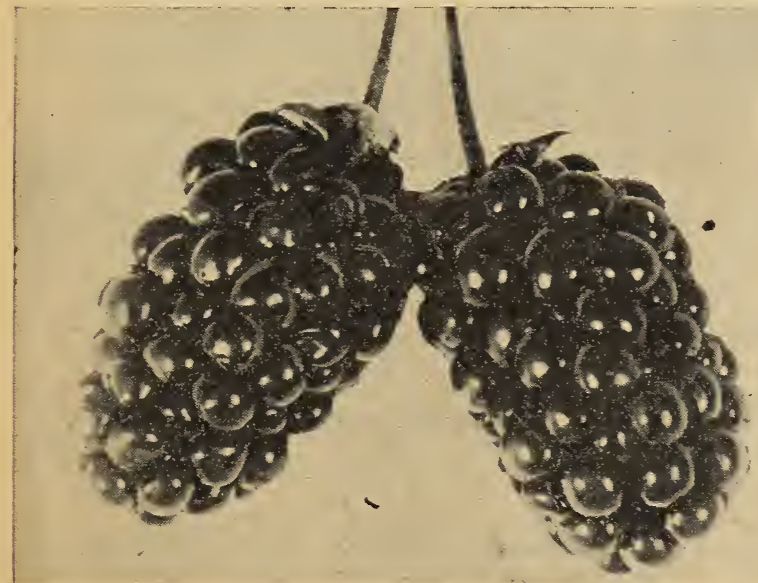
practically unexcelled.

\section{LUCRETIA DEWBERRY}

The berries are far larger and in. comparably better than any black berry and of unequalled excellence; soft, sweet and luscious throughout; of brightest glossy black color. Price, $\$ 1.00$ per dozen; $\$ 3.00$ per $100 ; \$ 25.00$ per 1000 .

\section{AUSTIN DEWBERRY}

Earlier than Lucretia, same size. Price, $15 \mathrm{c}$ each; $\$ 1.00$ per dozen; $\$ 3.00$ per $100 ; \$ 25.00$ per 1000 .

BOOK ON TRANSPLANTING

This book will be mailed free to each and every customer for 1927 free of charge. Sent im. mediately upon receipt of order. 


\section{RED RASPBERRIES}

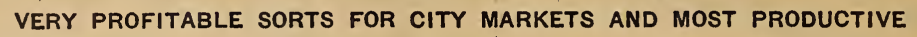

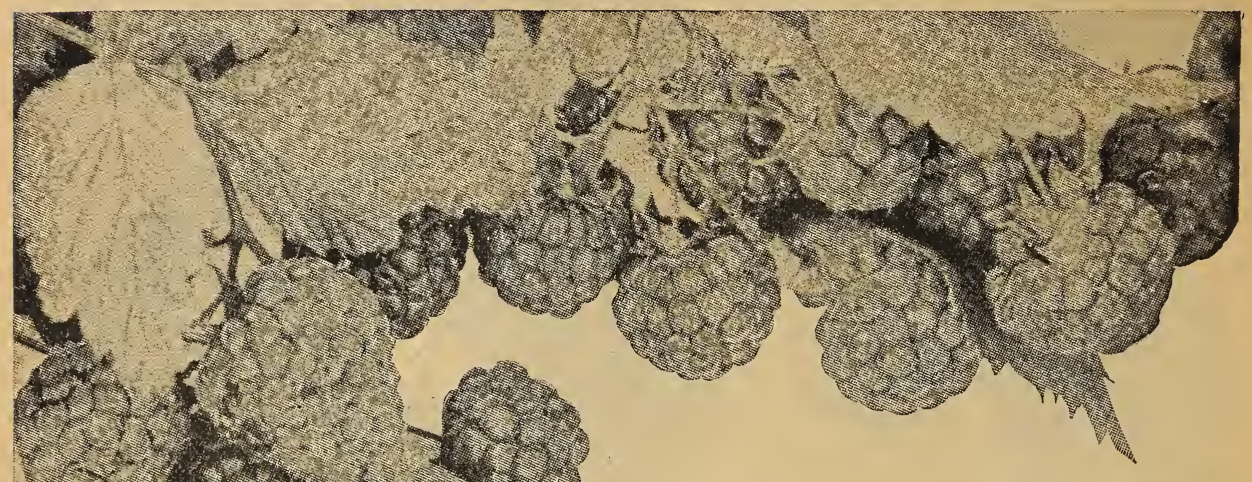

CUTHBURT $\begin{gathered}\text { An old standard variety that to } \\ \text { stifl the }\end{gathered}$ many sections. You can always depend on the Cuthbert. Price, 15c each; 75c per doz.; \$3.00 per 100.

GOLDEN QUEFN A yellow raspberry both as a novelty and for the home garden. Resembles Cuthbert in every way except the color of the berry. Price, 20c each; $\$ 2.00$ per dozen; $\$ 10.00$ per 100 .

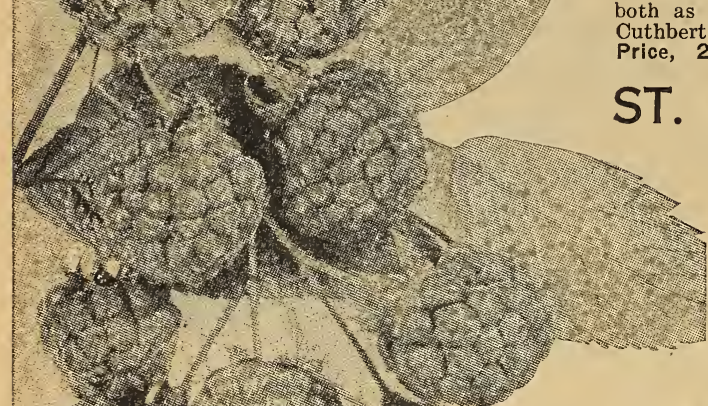

REGIS Everbearing Red Raspberry. Beare E in 80 days from planting. The introducd berbearing red raspberry ever because it actually does bear a big crop of luscious fruit in June and begins again in September. and bears continually until killed by hard freezing. It does not bear a few straggling fruits, but the bushes are bend. ing down with fruit in all stages of develop. ment, some half ripe and some full ripe. Valuable alike for market or the home garden. It succeeds upon all soils, whether light and sandy or cold and heavy clay, and the canes are absolutely hardy. always and everywhere, so far as tested. Market gardeners and fruit growers are making plenty of money from St. Regis. Price, good strong plants, 15c each; $\$ 1.00$ per dozen, postpaid; 100 for $\$ 4.00$, by express.

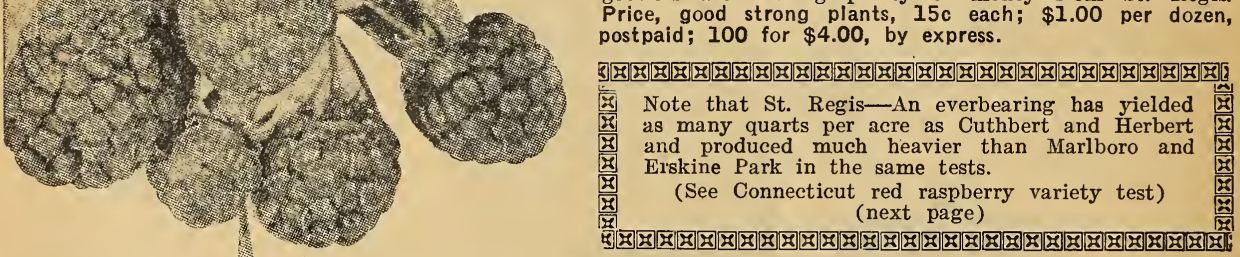

KIN Season very early. It is the early raspberry that makes the KING big money; often sells for $25 \mathrm{c}$ per quart. You want to add this one to your collection. "Round, medium size; light crimson colored; firm and of excellent quality. A seedling of Thompson and ripens about the same time, but larger and more productive." King is extremely hardy. Nothing compares to it in yield, beauty and firmness. We have a fine stock of strong plants. Order at once. Our plants are genuine. Price, $15 \mathrm{c}$ each; $75 \mathrm{c}$ per dozen; $\$ 3.00$ per 100 .

VICTORY (NEW) A new Red variety remarkable for its vigor, cextreme hardiness. It is a seedling of the Victory was originated in Northern Michigan, where it has withstood a temperature of 30 degrees below zero without injury to a cane. The originator has fruited this variety for more than 10 years, and in comparison with other varieties claims it is nsurpassed in its beautiful bright red color, which it retains after picking, and its delicious flavor. Price, 20c each; $\$ 1.50$ per dozen; $\$ 5.00$ per 100 .

HERBER Originated in Canada. It is a recognized fact that the farther north any fruit is grown, HERBER the better is its quality, and this "Child of the Northland" is no exception to this rule. The fruit is as large as the largest. It is as rich and highly flavored as the best, and by far exceeds any other kind in hardiness, rugged, thrifty constitution of plant, and is very productive. Price, 20c each; $\$ 1.00$ per dozen; $\$ 5.00$ per 100 . 


\section{LATHAM (Minnesota No. 4)}

\section{Yields Twice as Much as Other Red Raspberries}

Here is a new red raspberry that was originated in Minnesota and acclaimed for its hardiness in that state. During the past few years its merits have spread with its planting throughout the middle and eastern states. The high yielding ability of the Latham is due largely to its resistance to Mosaic and other red raspberry diseases; wherever tried, reports have been most favorable. It possesses the hardiness of "King" and produces very strong vigorous, thornless canes; very productive. Berries are large. of highest quality. ripen evenly and hold up well throughout the season. The canes do not need covering even in severe locations. We have a fine stock of this splendid new variety and hope you will give it a thorough trial, as we are sure it will prove a money-maker for you, especially in a season when other standard varieties freeze out. Price, 20c each; $\$ 1.50$ per dozen; $\$ 5.00$ per 100 .

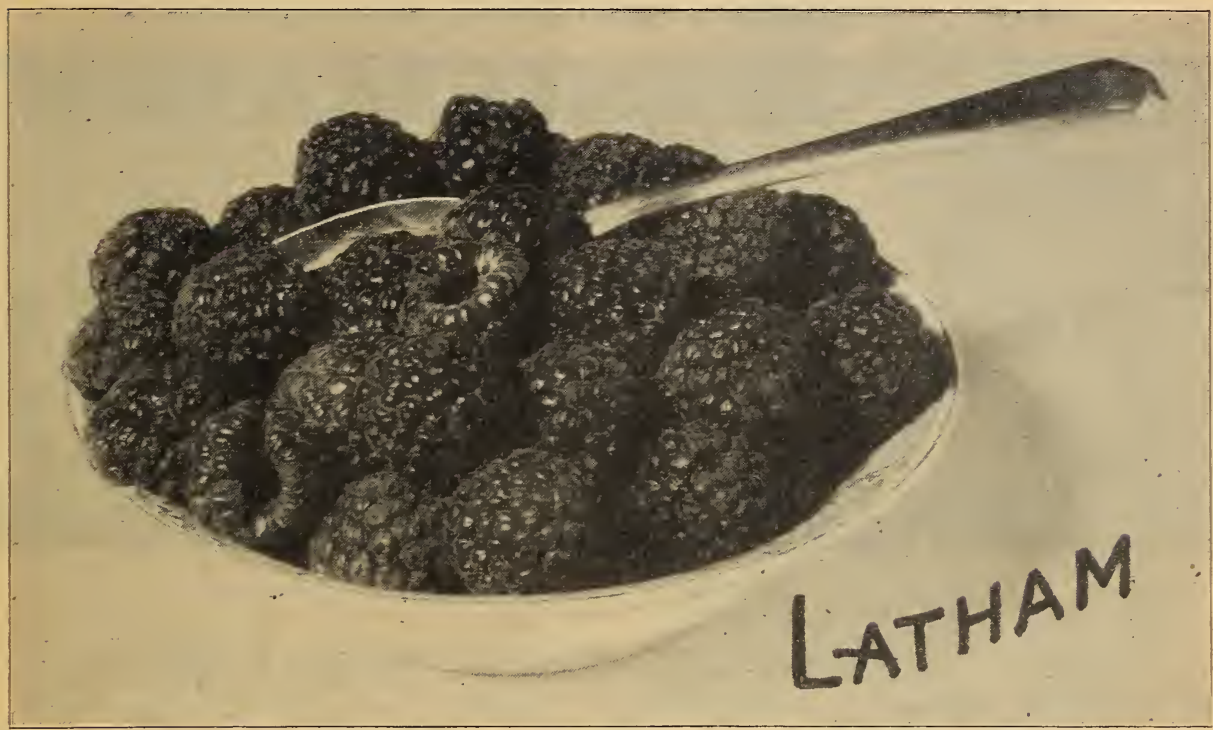

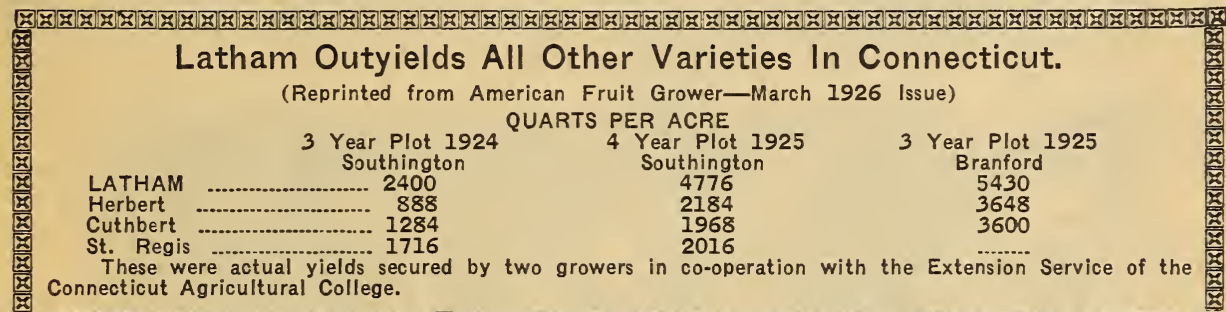

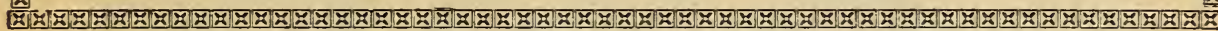

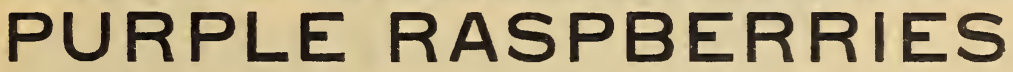

Grow Purple Raspberries for home use. They are unexcelled for canning, making pies, jams or for serving fresh or dessert.

COLUMBIAN The leading commercial variety of the purple type. Midseason, vigorous and purposes. Price, 20c each; $\$ 1.25$ per dozen; $\$ 5.00$ per 100 .

THE NEW CARDINALRASPBERRY This wonderful berry is a surprise in growth, extreme hardiness and the exceeding productiveness of its choice purple, pure-flavored berries. It great will pay. It is not a novelty. but a variety of great merit. The New Cardinal will grow ten feet, and bears in proportion. Leading horticulturists who have seen this berry say that it is one of the wonders of the century, so far exceeding all others as to put it entirely beyond comparison. Judge Wellhouse, President of the Bansas State Horticultural Society, said at the meeting of the Society that the introduction of the Cardinal Raspberry would add millions to the wealth of the farmers of the country because of its inherent great vigor and exceeding productiveness. Price, $20 \mathrm{c}$ each; $\$ 1.25$ per dozen; $\$ 5.00$ per 100 .

HAYMAKER is a purple cap not as dark as Columbian or Shaffer, and much larger and firmer than either of those varieties, never crumbles, and stands up well in and th local demand. So much of a favorite has the Haymaker become that for either home use or market. The originator has found it the most profitable berry ever raised for market. local growers have said that it has ruined the sale of other varieties. Very popular as a canning berry. Many orders for berries for this purpose are placed a year in advance. ... Price, $20 \mathrm{c}$ each; $\$ 1.25$ per doz.; $\$ 5.00$ per 100 . 


\section{BLACK CAP RASPBERRIES}

CULTURE Raspberries will do well on any upland soil that will produce a good corn crop. Land should CULTURE be thoroughly prepared and well enriched. Keep well cultivated and free from weeds. As soon as they are done bearing, cut out the old wood to give more vigor to the young canes. Plant in rows six feet apart and two and one-half feet apart in rows. Avoid wet lowlands.

WE GROW THE FINEST RASPBERRY PLANTS IN THE WORLD. OUR VARIETIES ARE THE KINDS THAT MAKE MONEY. THEY HAVE DONE IT FOR US. THEY WILL DO IT FOR YOU.

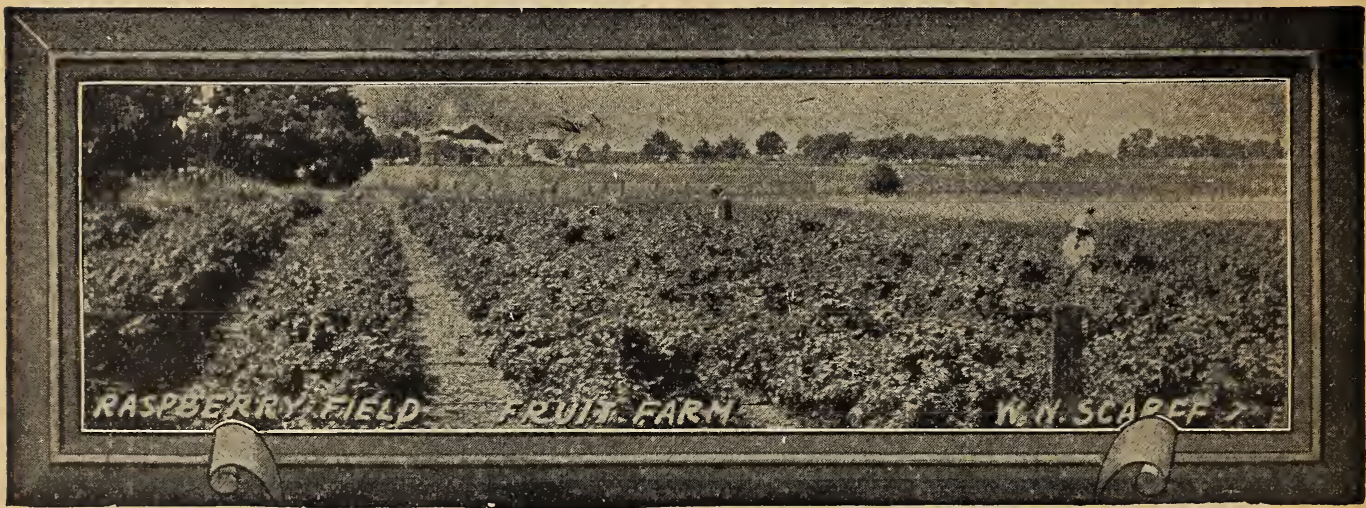

GPFGG An old variety of merit too well known to need description. Price, 75c per doz.; $\$ 3.00$ GREGG per 100; $\$ 25.00$ per 1000 .

KANSAS A well-known variety of merit. Fruit ripens early, is large, juicy and of good quality. $\$ 25.00$ per 1000 . PLUM FAMER This variety is now considered as one of the best of the standard varieties he fruit is early, ripening a week or more before Gregg, easily picked, a good shipper and one of the best to withstand drought. Berries are large, very attractive, firm, juicy and of good quality. Price, 75c per doz.; $\$ 3.00$ per $100 ; \$ 25.00$ per 1000 .

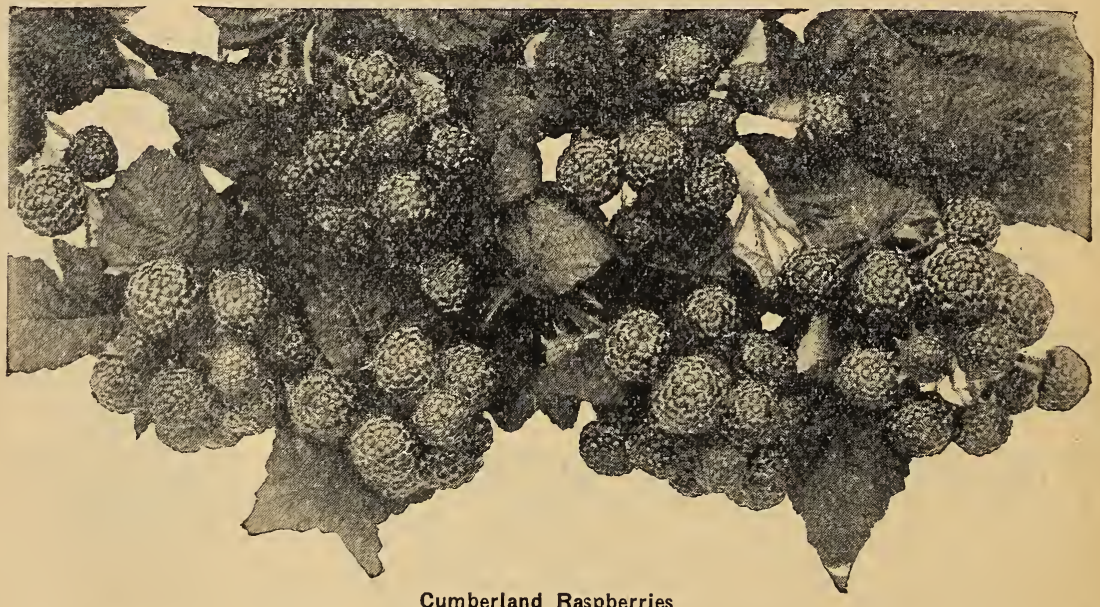

CUMBERLAND In hardiness and productiveness it is unexcelled by any other variety. In sixteenths of an inch in diameter and are of handsome appearance. In spite of seven eighths and fifteenpossessed of great firmness and is thus well adapted for standing long shipments. It follows Palmer and Souhegan and precedes Gregg a short time, making it a midseason variety. The bush is exceedingly healthy and vigorous, throwing up stout, stocky canes, well adapted for supporting their loads of large fruit. It has shown itself remarkably free from the scourge of its family, anthracnose. Large growers report yields of two and three times as much per acre as Ohio under same conditions, and far ahead of other varieties. Price, 75c per dozen; $\$ 3.00$ per $100 ; \$ 25.00$ per 1000 . 


\title{
SCARFF'S CURRANTS
}

\section{HAVE NO EQUAL FOR PROFIT AND PRODUCTIVENESS}

\begin{abstract}
Arsenate of Lead or Hellebore for worms.
Currants and Gooseberries can be planted as an Ornamental hedge row in the back yard or as a garden border. They will produce an abundance of beautiful fruit, excellent for culinary purposes, pies, jellies, etc.

As a commerical proposition for the city market or roadside market you will find the Currants a most profitable crop to grow and one that requires very little attention.

Our Currants will make money for you.

\section{CHERRY}

A popular well known variety largely planted for both market and home use. Plants vigorous, stocky, compact to spreading. Fruit bright red, large, juicy and fine flavor.

Price 20c each; $\$ 2.00$ per Doz.; $\$ 15.00$ per 100.

\section{RED CROSS}

No garden is complete without them. Easy to grow and sure to bear. Our list comprises only the very best in cultivation. Plant $3 \times 6$ feet. Use

We have grown this variety for a number of years on our Fruit Farm and find it one of the most profjtable currants that we grow. It was originated by the veteran horticulturist, Jacob Moore, "who counted it one of his greatest achievements. In size it is equal to Fay or Cherry and will, we are sure, yield as much again as these old favorites. The quality is good and size of berries uniform. The red clusters are large, making it very easy to pick. Our pickers pick three crates a day of the Red Cruss. It makes abundant wood growth, and it not much bothered by borers. Price, $20 \mathrm{c}$ each; $\$ 2.00$ per doz.; $\$ 15.00$ per 100.

\section{WILDER}

A remarkable variety for which we predict great popularity, both for table and market. One of the strongest growers and most productive. Bunch and berry very large, bright, attractive red color, even when dead ripe; hangs on bushes in fine condition for handling as late as any known variety. Oompared with the celebrated Fays, is equal in size, with much longer bunch, better quality with much less acidity; ripens at same time, continues on bush much longer; fully as prolific, in some trials largely outvielding it. Price, 20c each; $\$ 2.00$ per doz.; $\$ 15.00$ per 100 .

\section{FAY'S PROLIFIC}

Perhaps no other currant has received so much praise as the Fay. It is very large, and always sells well and at high prices. We consider it does better on heavy clay soil, well manured and thoroughly cultivated, than on lighter soils. Price, $20 \mathrm{c}$ each; $\$ 2.00$ per doz.; $\$ 15.00$ per 100 .

PEREFCTION Is a beautiful bright red. Size as large or larger than ER berry is well maintained to the end of the bunch. The Perfection has a long stem from point of attachment to the bush to the first berry, making it easy to pick without crushing any of the berries.

PRODUCTIVENESS. The Perfection is a great bearer. resembling its parent, the White Grape, in this respect; superior to the Fay or any large sort with which we are acquainted.

THE SEASON OF RIPENING is about the same as that of the Cherry or Fay.

QUALITY. Rich, mild, sub-acid, plenty of pulp with few seeds. Less acid and of better quality than any other large currant in cultivation. The White Grape has always been considered one of the best varieties for table use, and the effect of this strain is plainly seen in the very fine quality of Perfection.

VIGOR AND HEALTHFULNESS. In habit of growth it is intermediate between its parents. Fay and White Grape, with remarkably large, healthy foliage. Price, $25 \mathrm{c}$ each; $\$ 2.50$ per doz.; $\$ 20.00$ per 100 .

\section{INDON MARKET The home of this valuable currant is Michigan, where hundreds of acres - popular in that noted fruit section. The fruit is of good size, being larger than victoria, Versailles and consider this variety to be one of the most profitable that a fruit grower can plant either for commercial purposes or for the home garden. It is an all-around currant that gives universal satisfaction. The success of currant culture depends upon productiveness, size, and length of season the fruit will remain in prime condition on the bushes. London Market has all of these strong points and you are certain to make no mistake by planting heavily of this variety. Price, $20 \mathrm{c}$ each; $\$ 2.00$ per doz.; $\$ 15.00$ per 100 .} NOTE-See quarantine regulations next page on Currants and Gooseberries. 


\section{SCARFF'S GOOSEBERRIES}

OUR STOCK OF CURRANTS AND GOOSEBERRIES IS EXCEPTIONALLY FINE AND OUR VARIETIES ARE THE BEST, BEING HARDY, PROLIFIC BEARERS AND LARGE FRUIT. MAY BE PLANTED
EITHER SPRING OR FALL.

We are just now beginning to realize the immense profits in Gooseberry culture. It is really amazing to learn of the great vielis from a plantation that has been properly handled. $\Lambda$ half bushel per bush is not an uncommon yield. The Rural New Yorker has published some remarkable records from plantations in New York and Indiana. We advise you to investigate this line of fruit growing and get started at once so you can reap the big profits in the early stage of the game.

\section{CARRIE \\ (ALMOST THORNLESS)}

Carrie is one of the finest varieties of Gooseberries that is now in exjstence. Growers have found it of that thrifty robust nature that enables it to withstand considerable neglect, but at the same time responds quickly to extra care and attention. Originated in Minnesota. Vigorous and hardy, produsing an abundance of leaves, free from mildew and anthracnose, nearly thornless. Fruit larger than Houghton, turing deep maroon when ripe; flavor excellent. Price, $30 \mathrm{c}$ each; $\$ 3.00$ per dozen.

\section{JOSSELYN}

General favorite among fruit growers. Large size, pink color when ripe, smooth, prolific and hardy. Carefully tested everywhere and one of the most profitable to grow for market. Freo from mildew in both leaf and fruit. Foliage healthy, bright and clean. Bush strong, upright grower. Price, 30 c each; $\$ 3.00$ per dozen.

\begin{tabular}{l}
\hline QUARANTINE NOTICE \\
Owing to White Pine Blister \\
quarantine no orders for Currants \\
or Gooseberries will be accepted \\
from the following states: \\
Washington, Oregon, Montana, \\
Idaho, Nevada, California, Wyo- \\
ming, Utah, Arizona, North Dakota, \\
South Dakota, Nebraska, Colorado, \\
New Mexico, Kansas, Oklahoma, \\
Texas, Georgia, New Hampshire, \\
North Carolina, South Carolina, \\
N. Y., W. Virginia, Maine, Tenn. \\
\hline
\end{tabular}
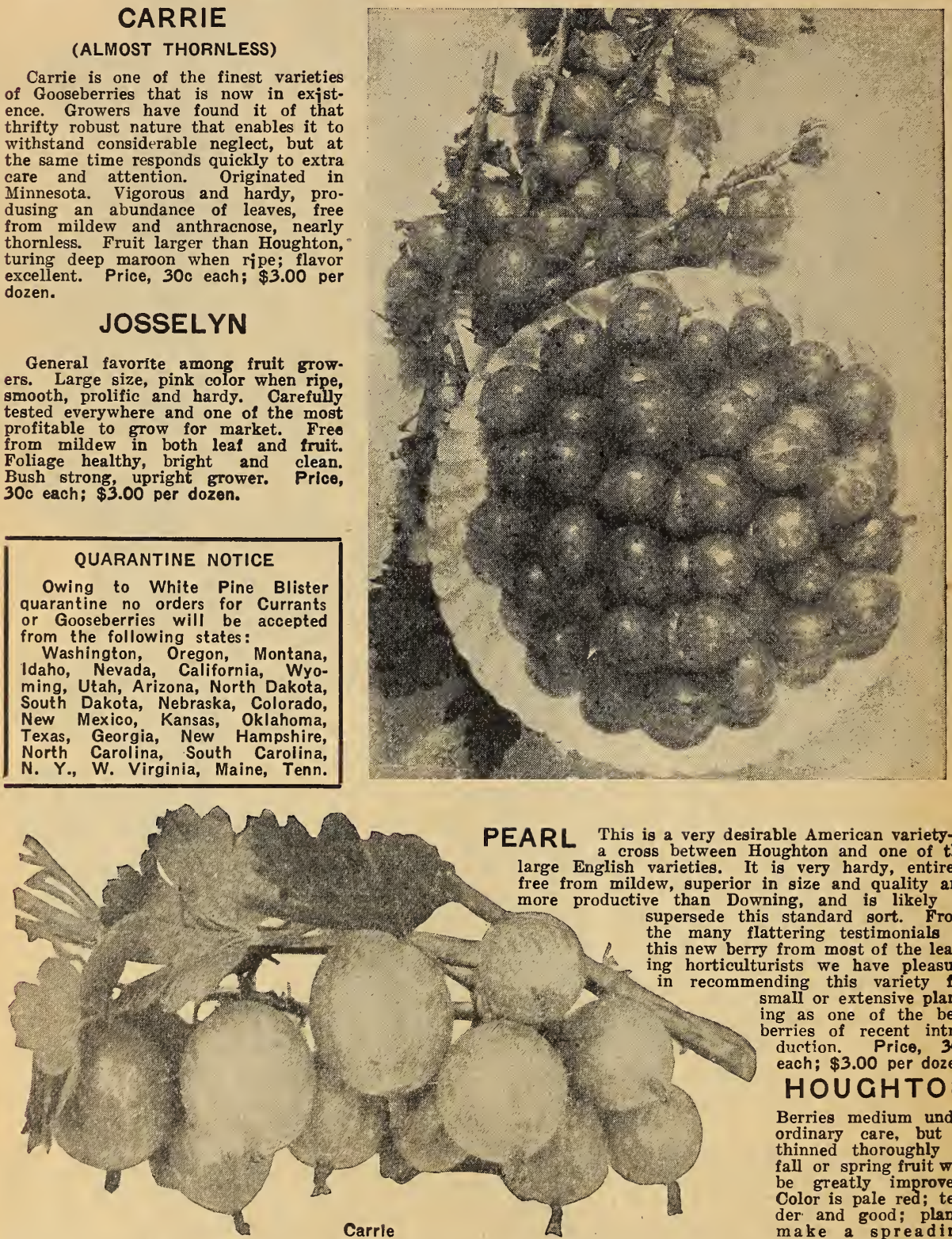

der wood; enormously productive. Price, strong plants, $30 \mathrm{c}$ each; $\$ 3.00$ per dozen.

DOWNING A large, handsome fruit, green in color; fine flavor; immense cropper and always in demand D ancy prices. American variety, free from mildew; bush strong grower; wood thick and strong. Price, strong plants, $30 \mathrm{c}$ each; $\$ 3.00$ per dozen. 


\section{GRAPES}

Every home should have a dozen or more grape vines planted on an Arbor or along the garden fence. They are delicious to eat fresh from the vines; can be made into the most health producing grape juice; and jellyWell who doesn't like grape jelly. Once planted the grape vines will continue to yield for years with practically no special attention. Our grapes are strong well rooted plants that are sure to grow for you.

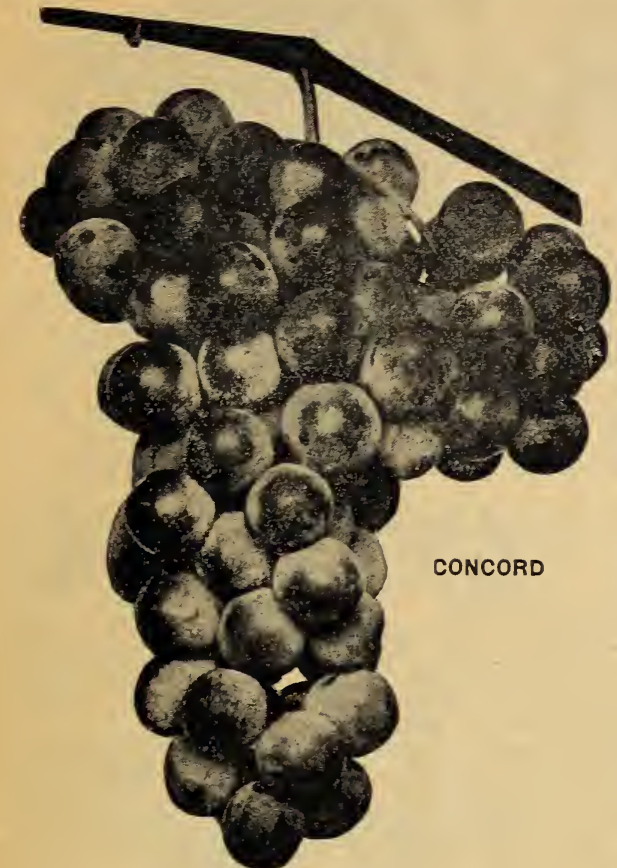

\section{WORDEN \\ (BLUE)}

A valuable blue grape ripening from three days to a week before Concord. Berry large, of good quality; thin skin; very productive; vine a strong grower. The most popular blue grape grown today. It comes in early enough to avoid the rush of Concords, thus brings 1 to 3 cents per pound more. Price, $30 \mathrm{c}$ each; $\$ 3.00$ per dozen.

\section{MOORE'S EARLY}

(BLUE)

A large blue grape, ripening a week earlier than Concord; good grower; berries large, good quality, and makes a moderate yield; very valuable as an early grape. Price, $30 \mathrm{c}$ each; $\$ 3.00$ per dozen.

\section{NIAGARA \\ (WHITE)}

The most popular white grape in existence. Fruit large and very productive; a good grower; ripening same season as Concord; equally good; valuable in every way. Price, $30 \mathrm{c}$ each; $\$ 3.00$ per dozen.

\section{BRIGHTON}

(RED)

One of the best red grapes in cultivation. Bunch large and compact; a strong grower and very productive; quality good. Price, $30 \mathrm{c}$ each; $\$ 3.00$ per

\section{CONCORD (Blue)}

An old variety; does well wherever planted; good adze; productive. Price, $30 \mathrm{c}$ each; $\$ 3.00$ per dozen.

\section{MOORE'S DIAMOND (White)}

The color is a delicate greenish-white, with a rich yellow tinge when ripe. Very few seeds, juicy, and almost transparent. Berry size of Concord and two weeks earlier. Price, $3 c_{0}$ each; $\$ 3.00$ per dozen.

\section{CACO (New Red Grape)}

A variety of exceptional merit and should be in every collection planted. It combines more good qualities than any other varjety introduced in many years.

The Caco is perfectly hardy in all parts of the country. It has been pronounced by the best growers in America to be equal in quality to any variety grown, either out of doors or under glass. It is the most beautiful of the hardy grapes, the bunches are large, well shouldered, color wine red with abundant bloom. Bunches are compact and of good size and form. Earlier than Concord and is sweet and palatable several weeks before it is fully ripe. The vine makes a very strong growth, hence is valuable for covering trellis or screens. Caco is beyond doubt one of the best of our native grapes.

Price, 50c each; $\$ 5.00$ per dozen.

\section{CATAWBA (Red)}

One of the best known and widely grown of the red varieties. It is the leading red grape in com merce and grape-juice making. A strong grower and productive under a wide range of cultural conditions. Fruit attractive in appearance, good flavor and keeps well. Price, $30 \mathrm{c}$ each; $\$ 3.00$ per dozen.

\section{AGAWAM (Deen Red)}

Deep red, large bunch, berries large, meaty with rich aromatic flavor. Ripens a little after Concord. Price, $30 \mathrm{c}$ each; $\$ 3.00$ per dozen.

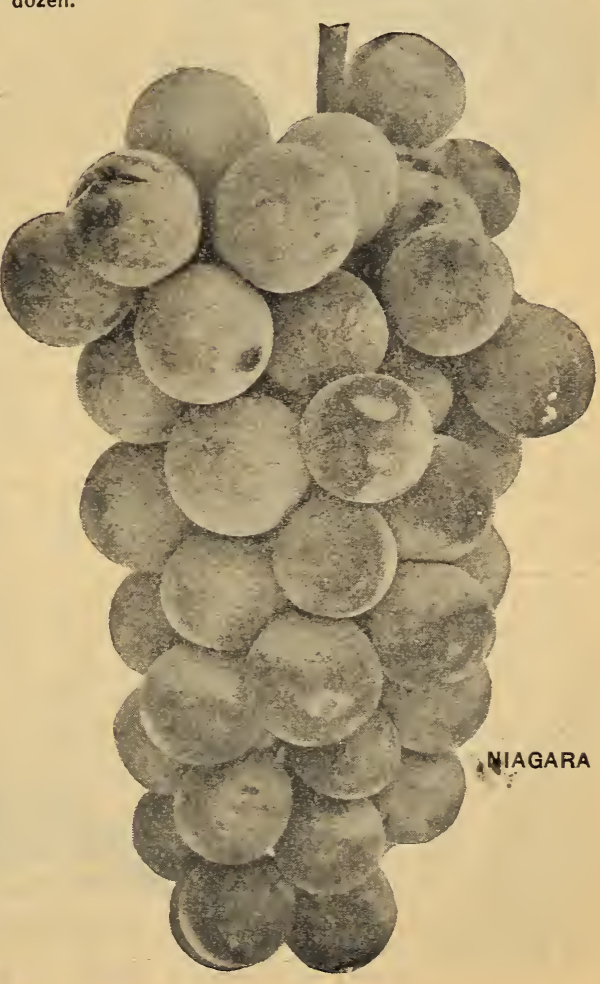




\section{Novelty Fruit Collection}

Different from ordinary fruits, and should be planted by everyone loving rare specimens. They are of but little value for commercial purposes. Plant in a small way only as Novelties and they will surprise and well repay you.

Strawberry-Raspberry Valuable for the extreme North, young growth, and is of course hardy in any climate. This is an entirely new fruit, both in habit of growth and form of fruit. Bushes grow 1 to 3 feet high, and are covered with red berries in the shape of strawberries. They are upright in manner of growing. Perfectly hardy, bound to become a valuable addition in the fruit line. It is very productive and a distinct novelty in small fruits. Price, 15 cents each; $\$ 1.50$ per dozen, postpaid.

Japanese Wineberry Ornamental both in fruit and plant. hairs. Fruits in large clusters and each berry at first tightly enveloped by the large calyz, forming a sort of burr, which is covered with purplish-red hairs. These gradually open and turn back, exposing beautiful wine-colored fruit of medium size, rich sub-acid, retaining flavor when cooked; highly esteemed for canning, preserves, jellies, etc. Price 25 cents each; $\$ 2.50$ per dozen, postpaid.

Huckleberry Many persons prize the fruit of the Hucklebe grown successfully in most parts of the U. S. They love a cool moist soil, partially shaded, as they grow wild under such conditions. Price, 25 cents each; $\$ 2.50$ per dozen.

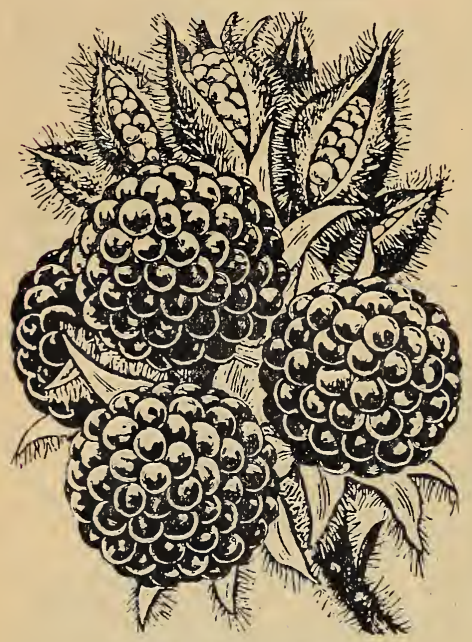

Japanese Wineberry

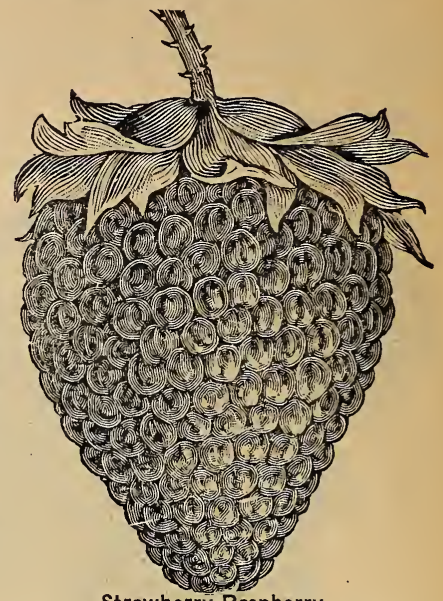

Strawberry-Raspberry

Improved Dwarf Juneberry A good substitute for huckleberry, or whortleberry, which it resembles in appearance and quality. The fruit is borne in clusters, and is reddishpurple in color, changing to a bluish-black. In flavor it is mild, rich sub-acid; excellent as a dessert fruit or canned. The bushes are extremely hardy, enduring the cold of the far North and heat of summer without injury. When this fruit becomes better known to the public it will be very' popular. It is much larger and better flavored than the Wild Juneberries. Price, 25 cents each; $\$ 2.50$ per dozen.

Himalaya Berry A new freak in horticulture which has Extravagant caused ... a ..great .furore ...among ..fruit troducer, but with us it is a failure. We have genuine plants from the introducer and if you want to try it we will be glad to furnish you the plants, but if you expect any great thing from the Himilaya, then we say go slow. Price, 20 cents each; $\$ 2.00$ per dozen, postpaid.

The Loganberry A hybrid between the Raspberry and the Blackberry. The fruit is as large as the largest Blackberry, and is produced in immense clusters. The color is a clear, dark red. It partakes of the flavor of both the Blackberry and the Raspberry-mild, pleasant, vinous flavor, delicious and peculiar to this berry alone. Seeds small, soft and few. Berries very firm, and carry well. Strong grower; enormous bearer. Fruit ripens early, just after strawberries. Not hardy north of 40 th parallel without protection. Price, 50 cents each; $\$ 5.00$ per dozen, by mulil, postpaid.

Crystal White Blac erry this is a real creamy white Blackberry. Mixed with the jet black ones for dessert it makes a most wonderful dish. The fruit is about the size of Snyder, with few seeds and quite sweet when fully ripe. The bushes are good, strong growers and very productive. This is not a worthless novelty, but a fruit of real value, and should be in every garden. Price 20c each; $\$ 2.00$ per dozen.

Elderberry This valuable fruit is becoming more popular each year. The fruit is fine for pies and to can for winter use. They may be planted anywhere about the yard, garden or field. The bush is highly ornamental and attractive when in bloom, and equally so when it is bending down with luscious fruit in early autumn. Price, 30 cents each; $\$ 3.00$ per dozen.

\section{POTATO EYES BY MAIL (Postpaid)}

For many years we have been furnishing our customers good, sound potato eyes by mail. It saves high freight and allows you to get a start of new varieties for a mere nothing. These potato eyes give the very best of sat-

isfaction. Remember they come by mail, postpaid, and are sure to grow. Try our new kinds. At a very small expense you can grow an experimental patch for exhibition. It is very interesting and profitable. 75 eyes should produce a bushel or more of good, sound potatoes, any variety. Varieties we can supply. Six Weeks, Early Ohio, Irish Cobbler, Rural New Yorker, Seneca Beauty, and Petosky.

PRICES POTATO EYES (Postpaid): 12 eyes, 25c; 50 eyes, 50c; 125 eyes, $\$ 1.00 ; 250$ eyes, $\$ 1.75$; 500 eyes, $\$ 3.25 ; 1,000$ eyes, $\$ 6.00$. 


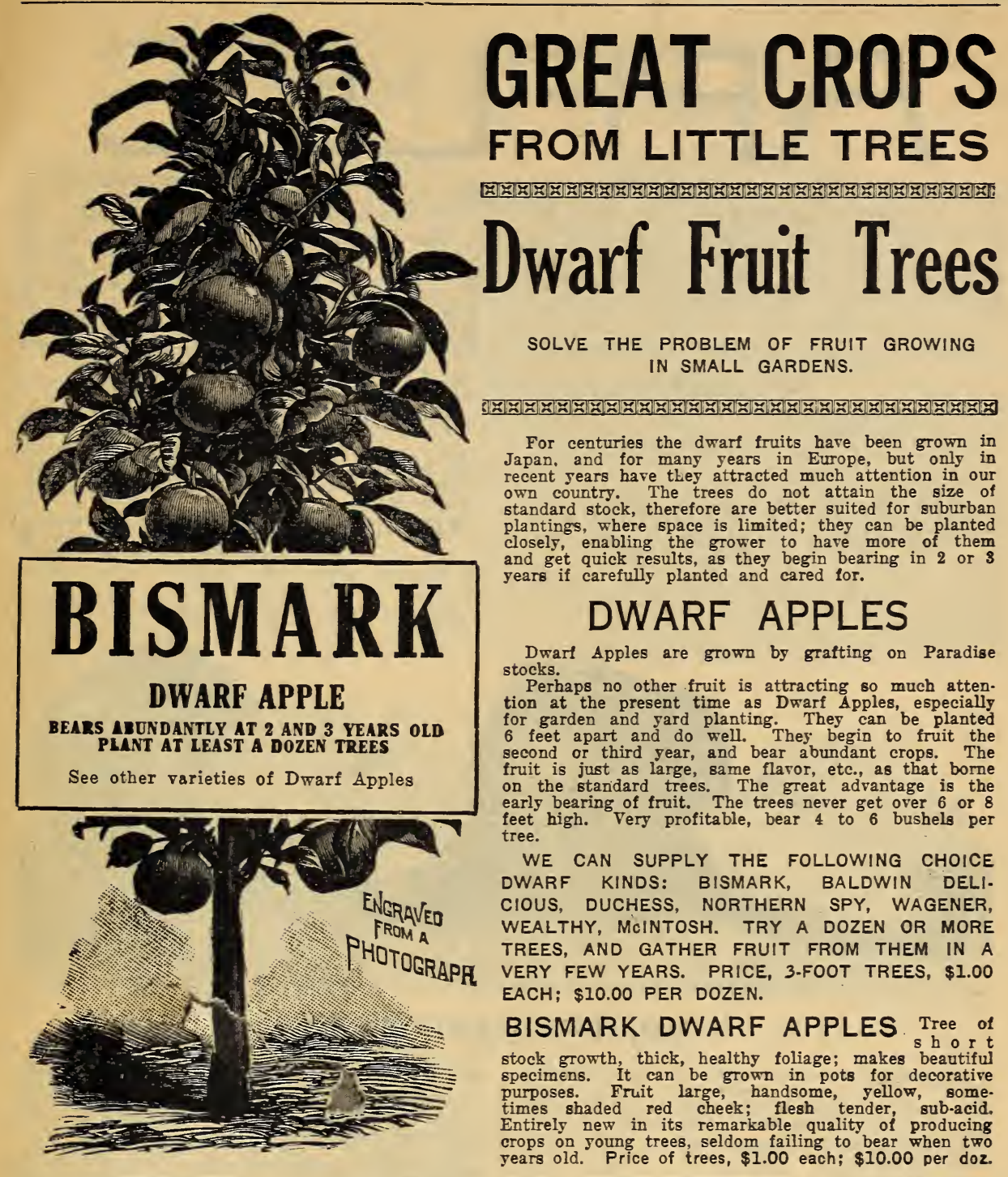

\section{DWARF PEARS}

May be planted $6 \times 6$ feet, and they will begin bearing in a very few years. The Dwarf Pears are grown by budding on Quince stocks.

The following varieties are particularly recommended for cultivation.

All are vigorous and handsome growers, bardy and productive.

KOONCE

KIEFER

WILDER

\section{BARTLETT
CLAPP'S FAVORITE
DUCHESS}

FLEMISH BEAUTY

Prlce of Dwarf Pear trees, three feet high, each, \$1.00; \$10.00 per doz.

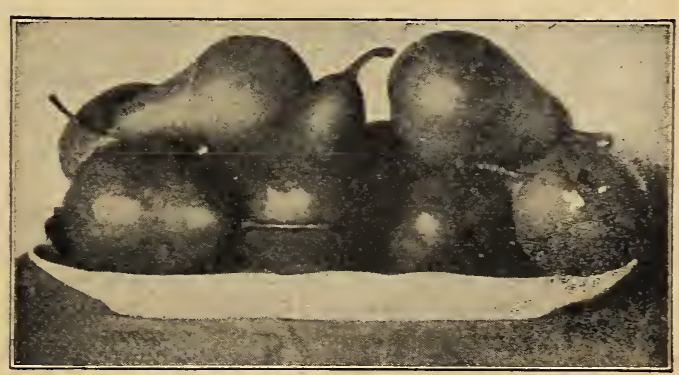




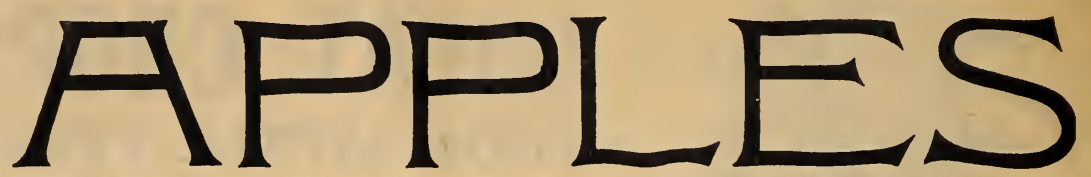

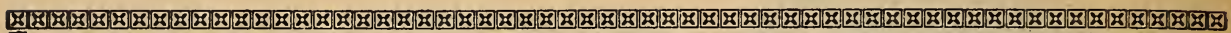

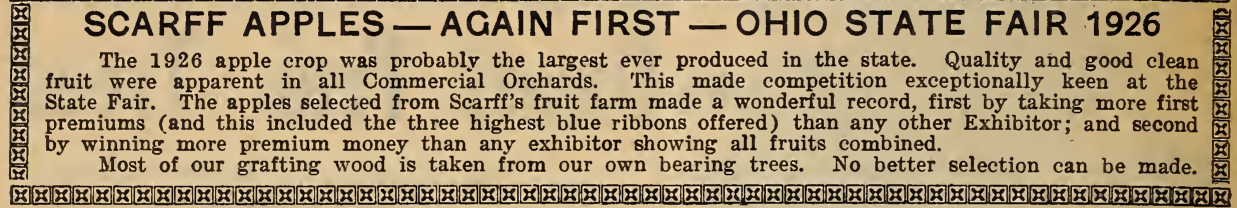
SUMMER AND FALL VARIETIES

TRANSPARENT Pale lemon yellow, very ripen and a fine market sort. Starts to bear good crops of fruit very young.

\section{DUCHESS OF Red stripped, underlaid with OLDENBURG clear yellow, Quality very ducer.}

WEALTHY One of the finest of the midsumjuicy and a reliable bearer.
MAIDEN BLUSH This is undoubtedly the most popular late summer variety grown. Like the Transparent the Maiden Blush produces good crops even when more or less neglected. For pies and baking purposes this variety is unexcelled.

JEFFERIS The Jefferis surpases all summer varieties for quality, making it especially desirable for planting in the home orchard. Fruit yellow, striped with light red; ripens over \& long season. The best for eating.

RAMBO WOLF RIVER SUMMER RAMBO

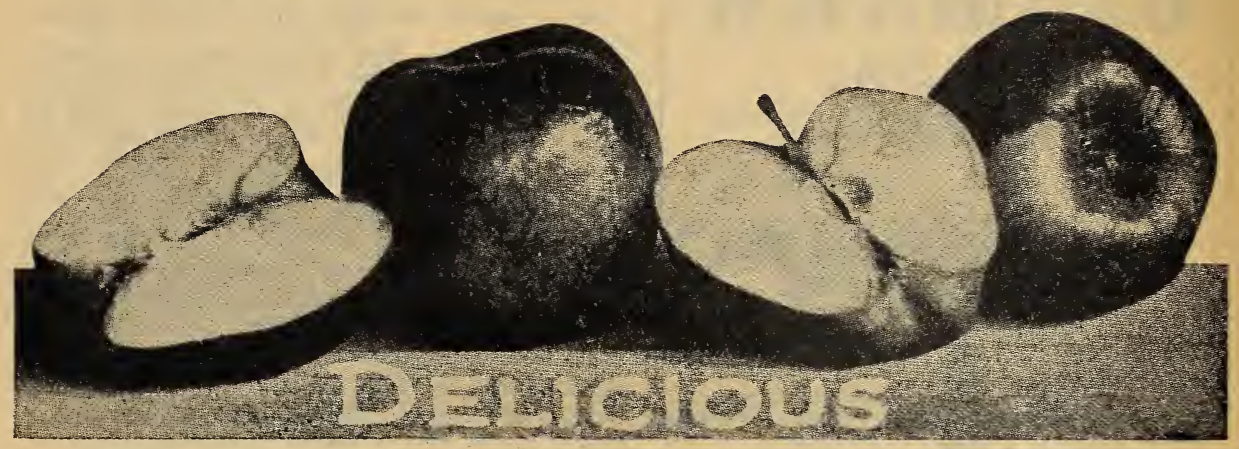

\section{WINTER VARIETIES}

BANANA A winter variety with decided banana Fruit is large, perfect in form, golden yellow beautifully shaded and marbled with bright crimson. Flesh lemon yellow, creamy texture and of the highest quality.

DELICIOUS A very popular variety. Fruit large and nearly covered with brilliant dark red. Flesh fine grained, crisp and melting with a delightful aroma; of very highest quality. A good keeper and shipper.

FAMUSE SNOW APPLE. Medium sized, roundFAMUSE ish, almost entirely red. Flesh white,

ducer, early winter.

ENSEE The fruit is larger, better colored, juicier and is more widely adapted than its parent, the Rome Beauty. The trees bloom about the same time as Grimes Golden and both buds and bloom will stand frost much better than the average. In the Northern Apple sections the Ensee is much better adapted than the Rome Beauty as it does not scab so badly and colors earlier. It hangs to the tree well after colored and keeps well in storage, rtaiening its crisp, juicy texture, and does not become dry and mealy as does the Rome.

\section{OTHER VARIETIES}

GRIMES GOLDEN, JONATHAN, WHITE PIPPIN, ROME BEAUTY, WINESAP, STAMENS, YORK IMPERIAL, STARK, NORTHERN SPY, N. W. GREENING.

PRICE APPLE TREES-75c each; \$8.00 PER DOZ.; \$60.00 PER 100.

\section{CRAB APPLES}

Varietles-Hysiop, Whitney, Transcendent. Price, 75c each; $\$ 8.00$ per dozen. 

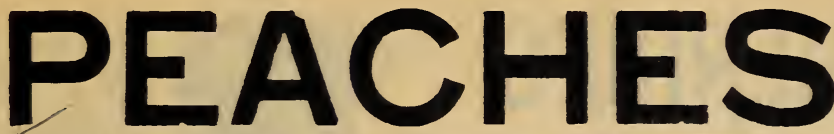

\section{BIG RED (SHIPPERS LATE RED).} where it is considered without doubt the best commercial peach on the market

Fruit is a perfect freestone, oblong, large to very large, averaging one-third or more above the best Elbertas; skin is a fine golden jellow almost completely covered with a splendid rich red making the well ripened fruit on the tree appear as if it were a solid red all over and texture of skin is such as to give the peach the highest shipping quality; flesh rich yellow, moderately fine grained (no fibre) juicy and of good quality; ripens about one week to ten days after Elberta; that is, it ripens in this section about the second week in September. In the orchard it makes a large spreading healthy tree-thus affording ample room for hanging the abundant crops it bears annually

Should never be planted closer than 25 feet for best results. The original tree, located in Morgan County, Indiana is now more than 20 years old and has only missed two crops since it began fruiting and, to the best of our knowledge, is still in good fruiting condition.

We find the Big Late Red to be of the Elberta type, but a great improrement orer that standard variety-as you can see by the above description. Price, strong trees, 75 c each: $\$ 7.50$ per dozen.

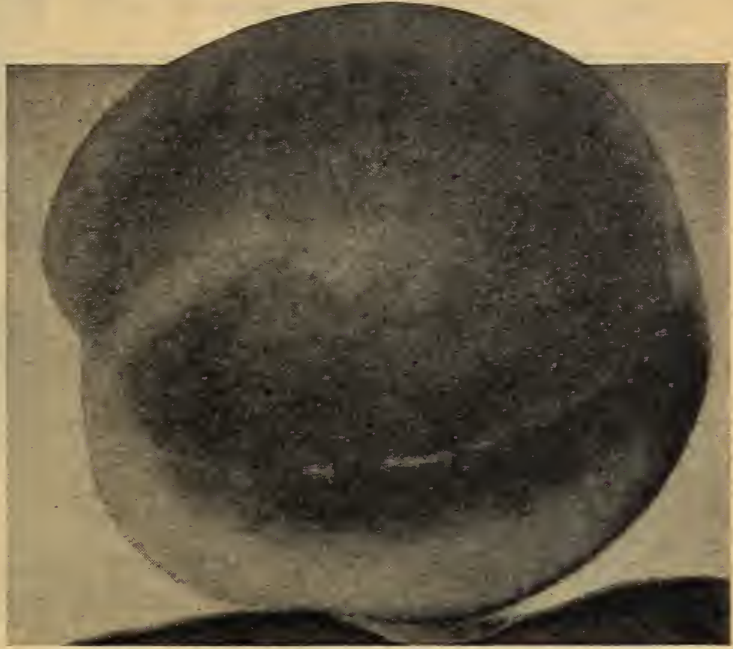

BIG RED (Shippers Late Red)

\section{STANDARD PEACHES}

Prices, except where noted, 4 to 5 feet, good trees, 60c each; $\$ 6.00$ per doz.; $\$ 45.00$ per 100 .

ELBERTA The standard commercial yellow variety of peaches. Heavy yielder and tree is a strong ELBERTA grower. Quality is good if allowed to ripen on tree. Freestone, midseason.

J. H. HALE Large size and beauty of the fruit are the two outstanding characteristics of the Hale. with red cheeks. Fine for desert or canning. Always brings fancy price on market. Fruit large jellow SMOCK Ripens quite late. Considered among the best for canning. Yellow freestone, good size and fine flavor.

CHAMPION The finest white peach grown. Ripens before Elberta. Excellent for eating and canning. Tree very hardy and robust grower. Do not fail to include the Champion in your plant-
ing. Fruit is large size, creamy white with red cheek.

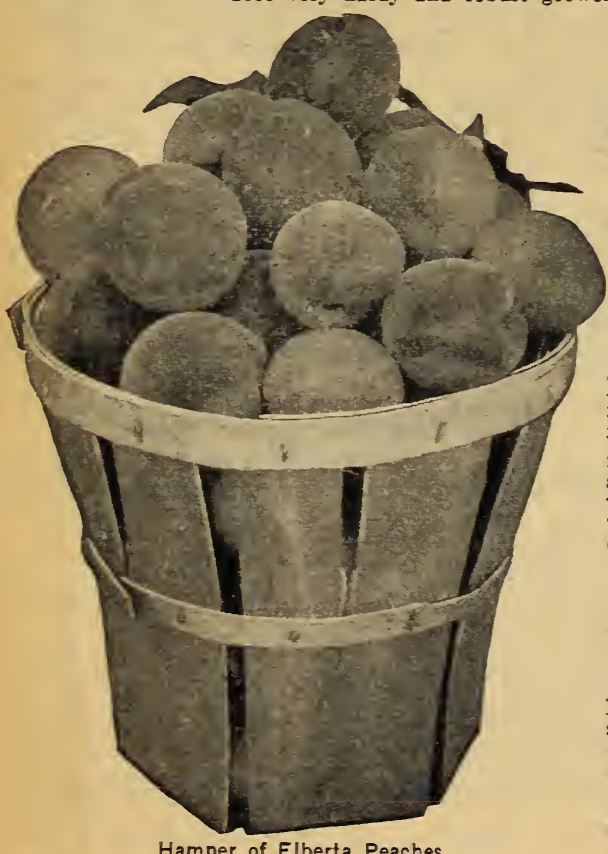

Hamper of Elberta Peaches

CROSBY. Valuable especially for the unusual hardiness of its fruit buds. Medium; bright yellow, with crimson splashes and stripes; very attractive; flesb bright yellow; red at the pit; juicy, rich. An abundant and regular bearer. Ripens before Crawford's Late.

CRAWFORD'S EARLY. One of the best early yellow peaches. Fruit large; rellow with a blush cheek; verg beautiful and productive. Last of July.

\section{MAYFLOWER PEACH}

Practically frost-proof-it blooms very late thus quite safe from damage by ordinary frost. This new peach originated in North Carolina, and is the earliest veach in existence; besides its color is perfectly red, which makes it one of the best and most profitable market sorts in existence. It is perfectly hardy, an abundant cropper, and should be in every home collection of fruit. Mavflower is a cling peach. Price, good trees, $60 \mathrm{c}$ each; $\$ 6.00$ per dozen; mailing size, $50 \mathrm{c}$ each; $\$ 5.00$ per dozen.

\section{Apricot}

HARRIS HARDY APRICOT. The fruit is fully as large as the best Apricot grown in California, and so much better in quality as to make and hold a place in the market against the rery best from California. Price, $\$ 1.25$ each: $\$ 12.00$ per dozen.

NECTARINE. A very delicious, smooth skinned truit, which thrives wherever peaches will grow. Price, $\$ 1.00$ each; $\$ 10.00$ per dozen. 


\section{CHERRIES}

A GOOD COMMERCIAL CHERRY ORCHARD PAYS BIG PROFITS

Price, fine trees, 5 to 6 feet, well-headed and good roots, $\$ 1.00$ each; $\$ 10.00$ per doz.

GOV WOOD One of the best sweet cherGOV. WOOD ries. Large, light red, juicy and delicious. Tree healthy and a good bearer. Early June.

YELLOW SPANISH very large, yela popular variety. Is of Spanish origin. Sweet.

BLACK TARTARIAN ${ }^{\text {Dark red; qual- }}$

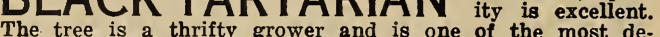
sirable sweet varieties to plant. Sweet.

EARLY RICHMOND . Dark red; mepopular. A standard and time-tried variety. Early May market.

MONTMORENCY Larger than Early days later, and is probably the best and most paying variety in cultivation for market. Best for canning.

No better time than now to plant Cherry trees, as the demand was never better for good frult.

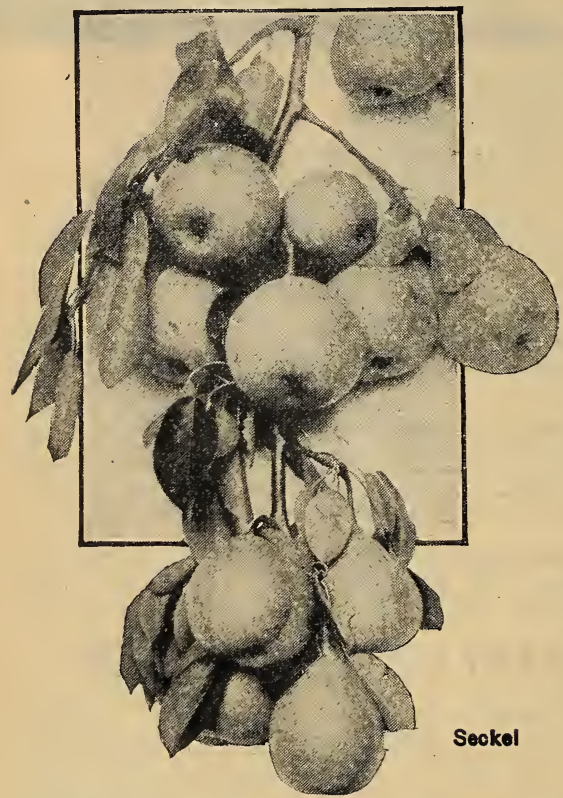

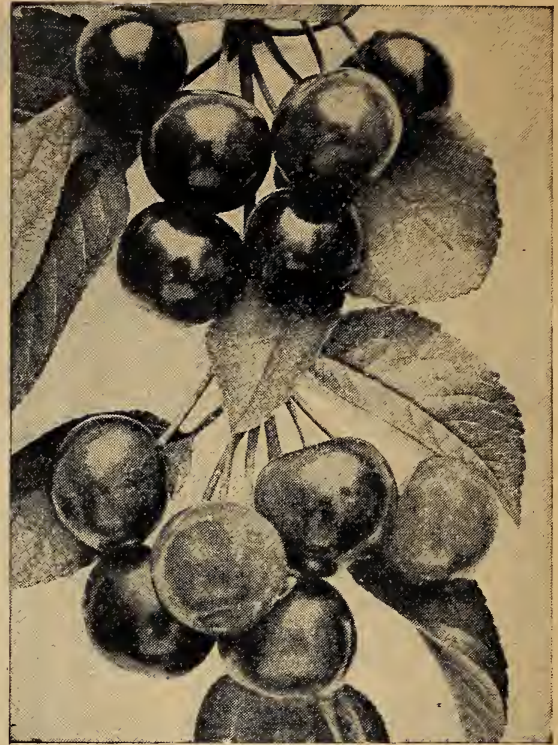

Early Richmond



Price, fine trees, $\$ 1.00$ each; $\$ 10.00$ per dozen.

SFCKFI Small, skin rich yellowish brown when SECKEL fully ripe, with deep brownish-red cheek; flesh very fine grained, sweet, exceedingly juicy, melting in the mouth.

DUCHESS very large, buttery, rich, juicy, exand is the most popular market variety as a dwart.

KIFFFFR An offspring of the Sand Pear and KIEFFER Bartlett; a very ornamental variety, owing to its beautiful foliage. Bears very young, often fruiting in the nursery row. Fruit never rots at core. September and October.

WILDER EARIY The claims of this pear WILDER EARLY are early ripening, productiveness, high quality and healthy growth; also long keeping qualities.

BARTIETT Size large, with blush next the BARTLEIT sun; quite juicy; excellent flavor; fruits when quite young. One of the most popular. July and August.

WE CAN FURNISH OTHER STANDARD VARIETIES OF PEARS AT THE ABOVE PRICES.

Prices, good trees, $\$ 1.00$ each; $\$ 10.00$ per dozen.

MOORE'S ARTIC. Very hardy; a prolific bearer; dark purple; flavor fine.

SHIPPER'S PRIDE. A large blue plum; very hardy and productive; esteemed for market.

REINE CLAUDE. Bavey's Green Gage. Very large, greenish; fine flavor.

GERMAN PRUNE. A valuable plum of fair quality for dessert. Long oval purple with a thick blue bloom; flesh firm and pleasant, separating from the stone. September.

BRADSHAW. Very large fruit; dark red; flesh inclined to yellowish-green.

LOMBARD. Size medium; dark blue; sweet, good. A variety valuable for market. A great producer of fine blue plums. Most popular variety of blue plums grown.

ABUNDANCE. A very early bearer, and $j \mathrm{t}$ bears such loads of fruit that it is often necessary to prop the limbs to keep them from breaking. Fruit large. beautiful, and of an amber color. Flesh yellow. tender, sweet. RED JUNE. A vigorous, hardy, upright, spreading tree as productive as abundance, with fruit equally as large. Small pit, juicy, reliable bearer.

BURBANK. It is one of the most promising of any variety of Japanese origin. Vigorous, strong branches. Frujt almost curculio-proof. A good shipper. June.

QUINCE CHAMPION. MEECH'S PROLIFIC, ORANGE. Strong trees of these varieties for $\$ 1.00$ each; $\$ 10.00$ per dozen. 


\section{Ornamental Shrubs}

Nothing will add more to the value and beauty of your home than a few of our beautiful flowering shrubs planted around the house and in the lawn. We are recommending only the ironclad shrubs which are perfectly hardy, the varieties which have proven their worth and bloom profusely under a wide range of con. ditions.

ALTHEA ROSE OF SHARON. Strong, erect-growAng shrub of easiest culture, perfectly hardy and a prolific bloomer. Large, showy flowers in hate summer when few other shrubs are in bloom. Assorted colors. Price, $30 \mathrm{c}$ each; $\$ 3.00$ per dozen.

BARBERRY JAPANESE BARBERRY (Berberis BARBERRY Thunbergi.) A most beautiful dwarf Barberry from Japan. Changing in autumn to beautiful tones of orange, scarlet, and crimson. Yellow flowers produced in early April, followed by red berries which are produced in great profusion and which last the entire winter. It fits in anywhere and everywhere and always looks fine, and at the foundation of the house or porch, along the side of waiks, in front of any tall-growing shrubbery, or as an individual plant on the lawn it is always in keeping with its surroundings. It is of low, dense, horizontal growth, graceful in all its branches. Absolutely hardy wherever planted. Price, large plants, 35c each; $\$ 3.00$ per doz. Hedge size, $\$ 15.00$ per 100 .

BOX BARBERRY For low hedges, edging, BO in $\mathrm{front}$ of other is very similar in appearance except that is a much lowe grower, compact, keeping a height of not more than 12 to 18 inches. Foliage is a deep green, turning to a brilliant red in autumn. Numerous red fruits in late summer, hanging on throughout the winter. Price, $30 \mathrm{c}$ each; $\$ 3.00$ per dozen; $\$ 20.00$ per 100 .

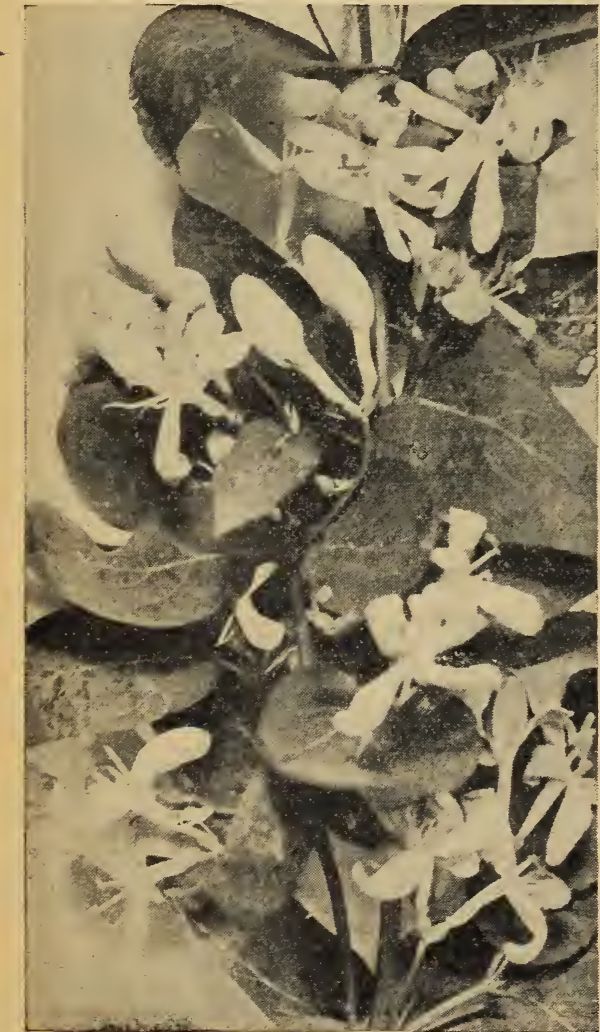

Bush Honeysuckle-Flowers White or PInk

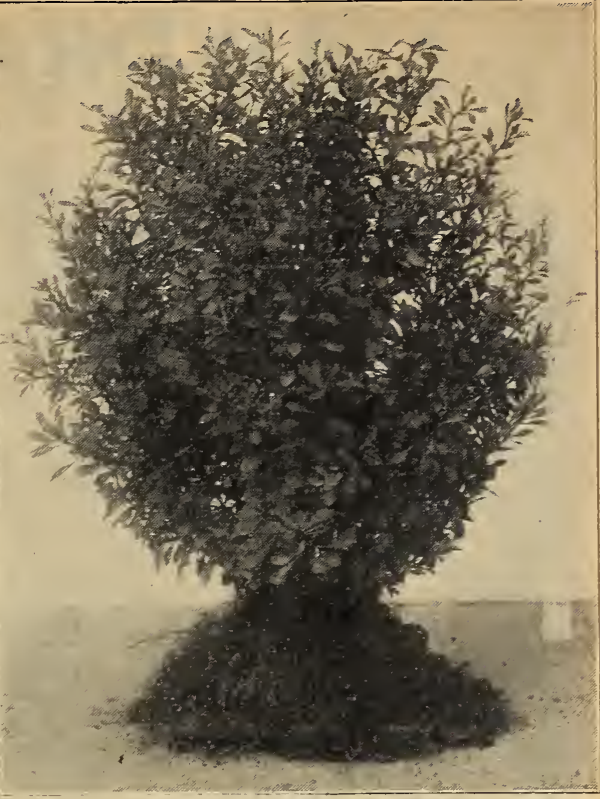

Box Barberry

DOGWOOD RED TWIG DOGWOOD. A very hardy, thrifty shrub, doubly attracive because of its creamy white flowers in early summer followed by clusters of white berries, and its very conspicuous blood red branches throughout the winter. Price, $35 \mathrm{c}$ each; $\$ 3.50$ per doz.

BUSH HONEYSUCKLE The Bush Honeycially desirable because they suckles are espeearly in thable because they come out in leat very 列 hout the year, producing numerous flowers in May and followed by very attractive red and orange fruits. We can furnish the white and pink flowering Tartarian Honeysuckle. Price, $35 \mathrm{c}$ each; $\$ 3.50$ per dozen.

DEUTZIA DEUTZIA, PRIDE OF ROCHESTER Shrub attaining a height of 4 to 6 feet, producing large clusters of white bloom in early June The foliage effect is good and it is a strong grower. Price, $35 \mathrm{c}$ each; $\$ 3.50$ per dozen.

EUONYMUS (Evergreen) This is a thrifty. growing little plant valuable as a ground cover or to plant in front of other shrubbery or used alone where a low planting is desired. This Euonymus retains its leaves throughout the winter and may be kept trimmed down to any height. Has a tendency to vine and is excellent as a wall cover on chimneys, lattice work, etc. Price, 30c each; $\$ 3.00$ per dozen.

DWARF BOXWOOD (Evergreen) Attains a oliage make this most desirable for edging along walks, around flower beds, paths or in front of other shrubbery. An excellent plant for porch boxes, and is perfectly hardy and retains the deep green color of the leaves throughout the winter. Strong 10 to 12 in. plants, 35c each; $\$ 3.50$ per dozen.

BUTTERFLY BUSH (Summer Lilac) This BUTTERFLYBUSH rare new flower is attracting attention of flower lovers everywhere and should be in every collection. It begins blooming in summer and continues without check until the middle of October. The flowers are valuable for cutting tor market, and have the fragrance of the old-fashioned Lilac. Price for strong plants, $30 \mathrm{c}$ each; $\$ 3.50$ per dozen, postpaid. 


\section{HYDRANGEAS}

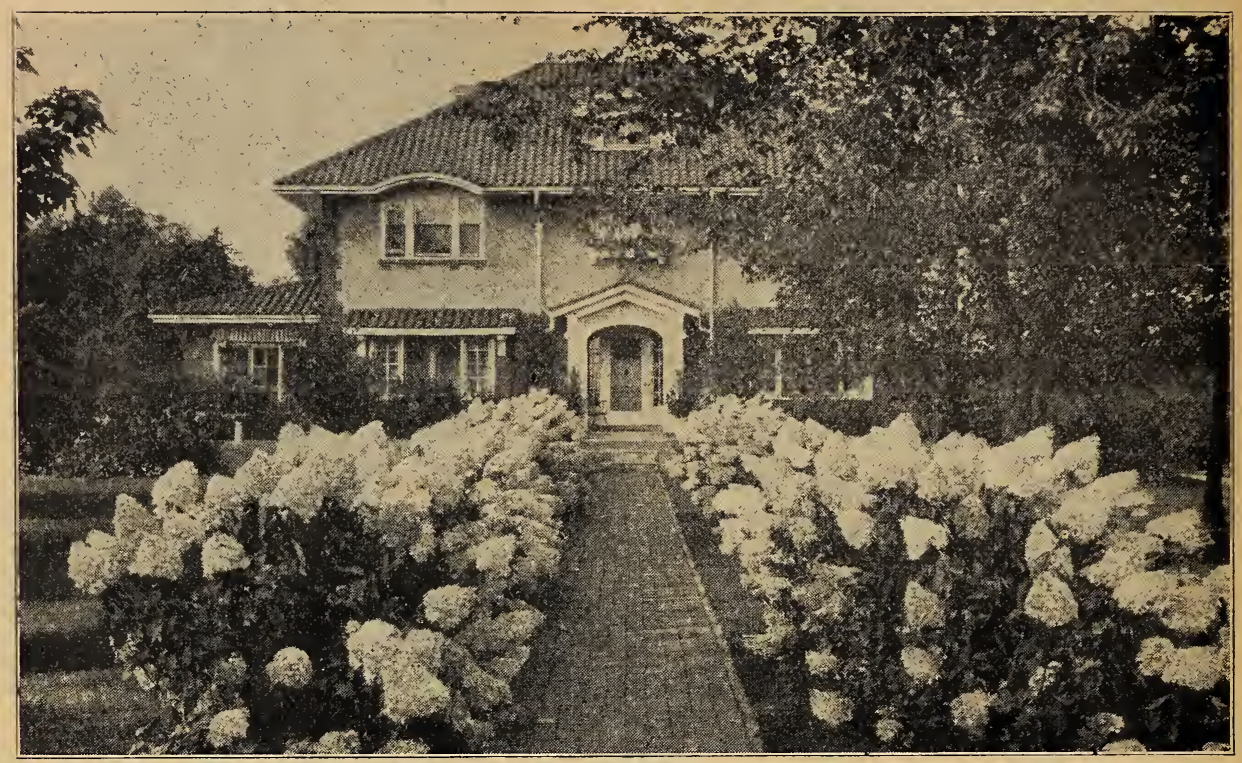

Hydrangea Paniculata Grandiflora

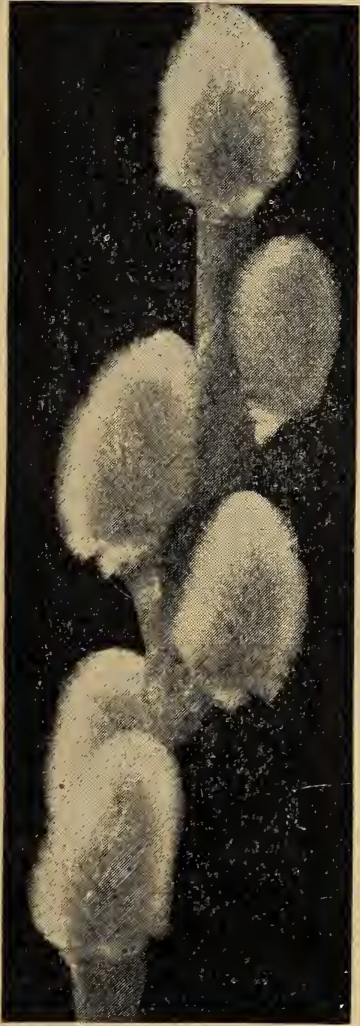

Pussy WIIlow

\section{HYDRANGEA PANICULATA GRANDIFLORA}

Has been very popular for thirty years or more, and millions of plants have been delivered to pleased customers the world over, and sales were never larger than at the present time. Price, strong plants, $35 \mathrm{c}$ each; $\$ 4.00$ per doz.

HDYRANGEA ARBORESCENS (Hills of Snow). This new A $y$ erican Everblooming ost beautiful hardy flowering shrub introduced during the past twenty years. The plant which attains a height of five or six feet, with near the same breadth, is by far more graceful in habit than the old form, with large trusses of beautifully formed flowers of dazzling whiteness, rendering this a plant of peerless beauty. It seems to thrive in various soils, and when fully exposed to the sun as well as in partial shade. The profusion of bloom of this new Hydrangea is yery unusual. There have been counted 100 good trusses on one plant-trusses $71 / 2$ inches in diameter. Price, $35 \mathrm{c}$ each; $\$ 4.00$ per dozen.

GOLDEN BELL FORSYTHIA SUSPENSA. You have noticed these graceful sprays of golden yellow flowers-about the first to bloom in the spring-that push themselves into the sunlight long before the leaf buds have burst. Branches have a tendency to droop, making a beautiful specimen shrub, or may be planted in a group with other shrubbery. Price, $35 \mathrm{c}$ each; $\$ 4.00$ per dozen.

PHILADELPHUS_SYRINGA Mock Orange. In the spring with masses of large, very fragrant, creamy white flowers. It is an old garden favorite. Price, $35 \mathrm{c}$ each; $\$ 3.50$ per dozen.

GOLDEN PHILADELPHUS Leaves bright golden color. Excellent for contrast with othe

INDIAN CURRANT Similar to the Snowberry, except that its INDIAN CURRANT fruits are red, and that the smaller red berries cluster in thick ropes along the weighed-down stems. Price, $35 \mathrm{c}$ each: $\$ 3.50$ per dozen.

SNOW BALL An old shrub of great merit. The beautiful large 35 plant is a good strong grower, attaining a height of 6 to 8 feet. Price, 35 c each; $\$ 3.50$ per dozen.

PUSSY WILLOWS Our new French Pussy Willows are a delight to all who see them. These large silvery flowers open up in late winter. They come as a Herald of Springtime. Plant them as a screen or hedge in the background, or plant as a tall shrub in your lawn. Their growth is compact and graceful. Price, $40 \mathrm{c}$ each; $\$ 3.00$ per doz. 


\section{New Red-Leaved Japanese Barberry}

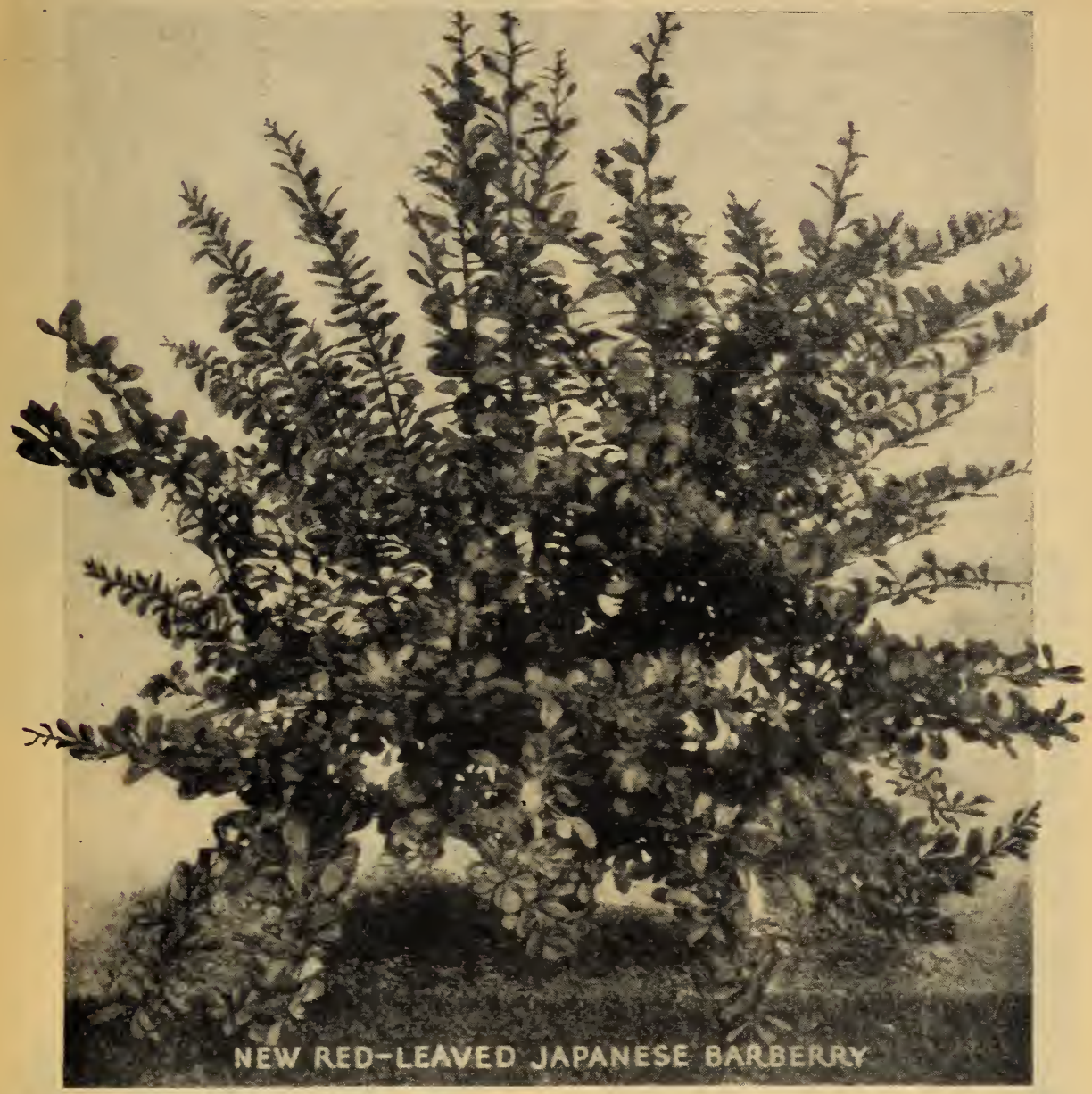

It is only once in a lifetime that a really worth-while, outstanding novelty in hardy shrubs is introduced, and in this new Barberry we have such a plant.

It is similar in all respects to the green-leaved Japanese Barberry which is so popular for mixing in the shrubbery border, as single specimens, or for planting in clump on the lawn, as well as for foundation plantings and for hedges, but the foliage of this new variety is of a rich, lustrous, bronzy red, similar to the richest red-leaved Japanese Maples. However, unlike these and other colored shrubs in which the coloring fades or disappears entirely as the season advances, this new Barberry becomes more brilliant and gorgeous throughout the summer, and in the fall its foliage changes to vivid orange, scarlet, and red shades, more brilliant and more effective than in the ordinary Japanese Barberry. In this coloring it is unequaled by any other shrub and is followed by the same brilliant scarlet berries common to the type, which remain on the plant the entire winter.

All that is required to develop its brilliant coloring at all seasons is that it be planted in full exposure of the sun.

Price, strong plants, 50c each; $\$ 6.00$ per dozen; $\$ 50.00$ per 100 . 


\section{Spirea Van Houttei}

Plant at least a half dozen of these beautiful white flowering shrubs about the lawn, and they will repay you a hundred fold.

In making a house and lawn attractive there is no better shrub than the Spirea Van Houttei. It is a plant growing about five feet high, with delicate leaves and clusters of white flowers. This shrub can be used in groups or in hedges with very good effect. The Spirea Van Houttei is one of the very best hardy plants for an ornamental hedge, or for artistic groupings, and it will bear clipping into com. pact form, as well as any shrub. Price, for large plants, $30 \mathrm{c}$ each; $\$ 3.50$ per dozen; $\$ 25.00$ per 100.

\section{SPIREA THUNBERGI} (SNOW GARLAND)

A very graceful. low growing shrub, excellent for foundation and border plantings. Attains a height of 3 feet and produces a profusion of miniature white flowers very early in the spring, often while the snow is still on the ground. Price, $45 \mathrm{c}$ each; $\$ 3.50$ per doz.

\section{SPIREA PRUNIFOLIA}

(TRUE BRIDAL WREATH)

This is an old-fashioned variety, flowers borne close to the slender erect branches in the spring before

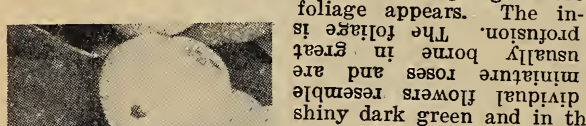

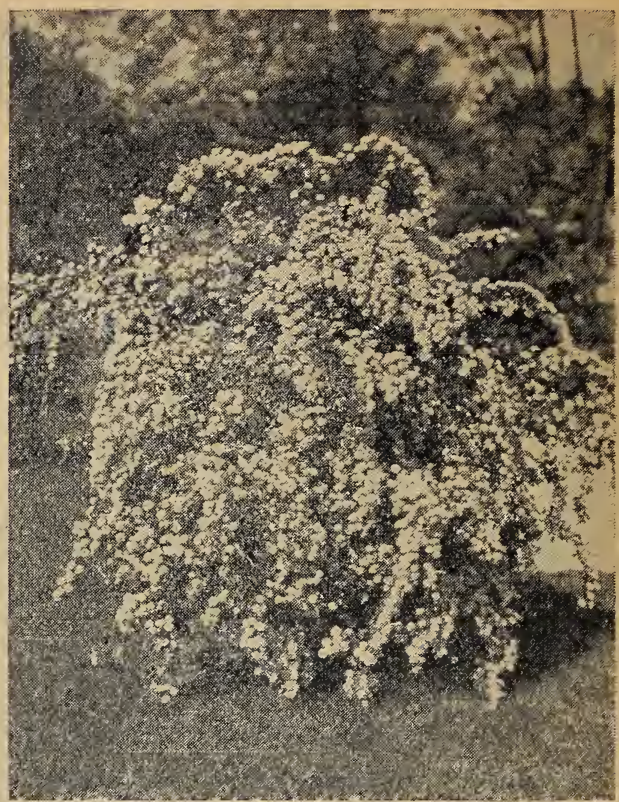

Spirea Van Houttei

\section{SPIREA ANTHONY WATERER}

Produces a red bloom about mid-summer and continuing to bloom for several weeks. It is extensively used in foundation plantings as it only attains a height of about 3 feet. Foliage buds out in very bright green early in the spring and may be kept trimmed down to almost any height. Valuable also for low hedge planting. Price, $40 \mathrm{c}$ each; $\$ 4.00$ per dozen.

\section{SPIREA BILLARDI}

(Red and White)

This is a beautiful upright growing Spirea reaching a height of 5 $-6 \mathrm{ft}$. that is good to plant back of the Anthony Waterer or Thunbergi. Price, $35 \mathrm{c}$ each; $\$ 3.50$ per dozen.

\section{SPIREA FROBELLA}

Similar to the Anthony Waterer, stronger growth. Flowers pink, blooming ove r long period. Price, 35c each; $\$ 3.50$ per dozen.

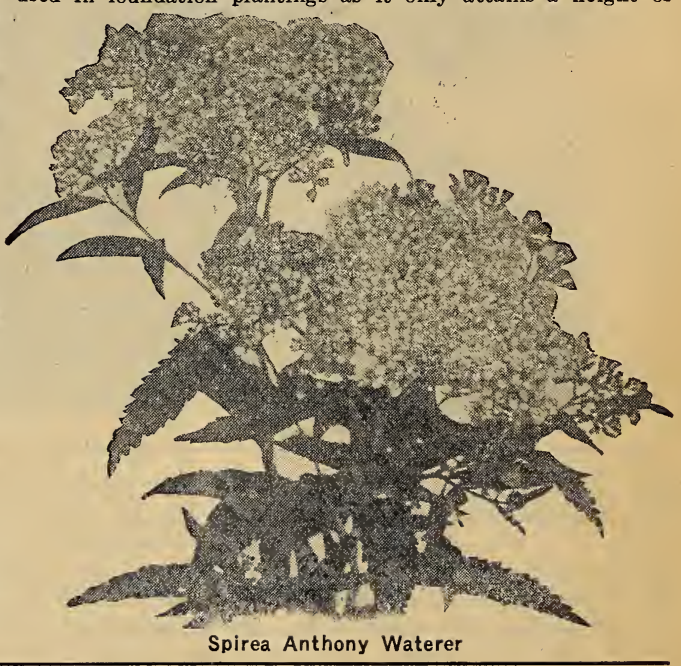

SPIREA COLLECTION POST PAID FOR $\$ 2.00$

Beautiful Bloom All Summer (Real Value \$2.40)

1 Spirea Anthony Waterer Red 40c 1 Spirea Billardi White - - 35c

1 Spirea Thunbergi White - - 45c 1 Spirea Frobeli Pink - - - 35c

1 Spirea Billardi Red - $35 \mathrm{c} 2$ Spirea Van Houttei White - $50 \mathrm{c}$ Seven Strong Plants By Mail, Postpaid, $\$ 2.00$

SNOWBERRY This is one of our most valuable shrubs for its winter fruit. and hang on nearly the entire winter. The low-growing habit makes it valuable for foundation planting, especially on north exposures and in shady locations. Price, $35 \mathrm{c}$ each; $\$ 3.50$ per dozen. 


\section{Japanese Barberry}

The Barberry excells as an informal hedge plant. Its low dense horizontal growth and graceful branching habit are well shown in the above illustration. When clipped the Barberry is fully as beautiful as the privets. Its outstanding good points are: A bright green foliage very early in the spring and this changing to beautiful shades of orange and red in the Fall of the year; and the attractive red berries which hang on all Winter and are sometimes retained until the plants leaf out the following Spring.

The Barberry produces a heavy root system and is very easy to grow. It forms a most beautiful and conspicuous low growing hedge, and one that is especially suited for making boundary lines. Equally as desirable for foundation planting as in a hedge. Price, hedge size, $\$ 15.00$ per 100 . Large plants, $35 \mathrm{c}$ each; $\$ 3.00$ per doz.

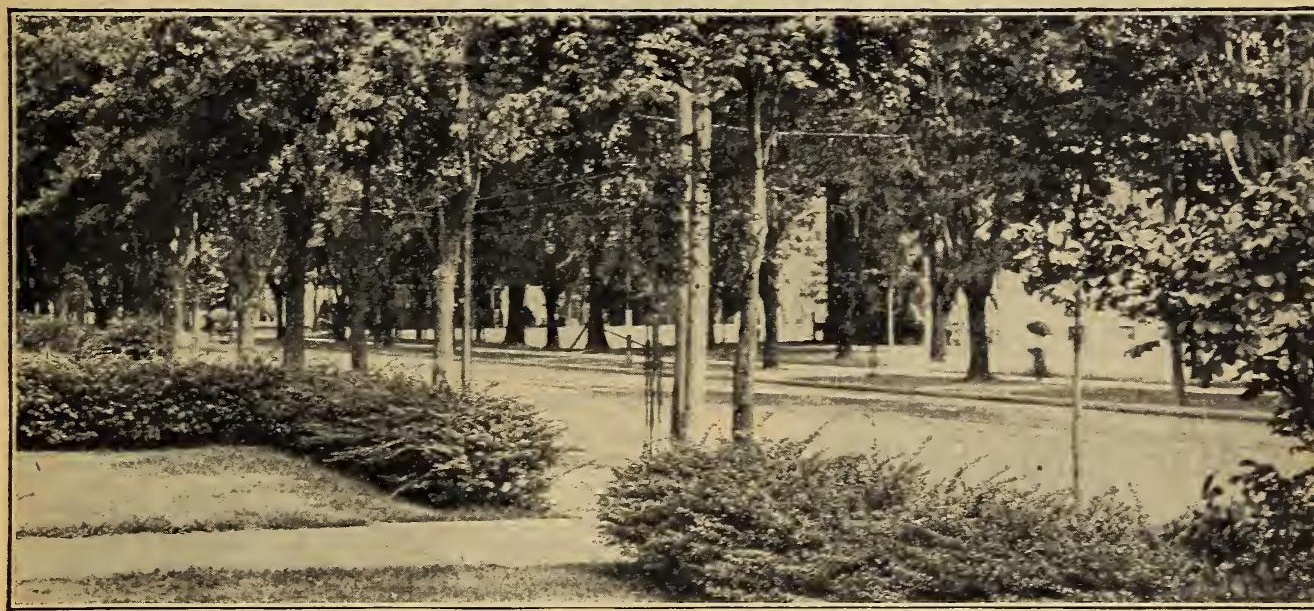

Japan Barberry (Thunbergi). Set Plants I Ft. Apart For Hedge.

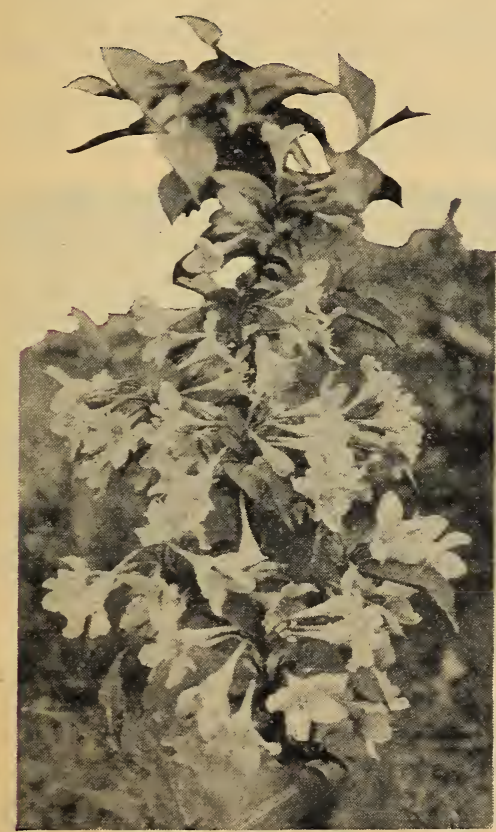

WEIGELIA ROSEA This shrub has, long been popular for ornamental plantdeep pink color in early June. A thrifty grower and one that vou will not want to omit from your planting. Price, $35 \mathrm{c}$ each; $\$ 3.50$ per dozen.

TAMARIX AFRICAN TAMARIX. A beautiful, tall, and producing an abundance of small purple flowers in May Strong, thrifty grower, especially valuable where used to cover a bare wall-space of a building or when planted back of other lower-growing shrubbery. Price, $35 \mathrm{c}$ each; $\$ 3.00$ per dozen.

YUCCA A hardy evergreen plant with long, narrow leaves that are bright green the whole year. The flowers are creamy white, bell-shaped, produced on long spikes 3 to 4 feet high. Fine stately lawn plant. Good strong plants, $25 \mathrm{c}$ each; $\$ 2.50$ per dozen.

ORNAMEMNTAL GRASSES B e a u $\mathrm{i}$ ful for Two leading varieties: Eulalia Japonica and Zebrina Variegata. Good strong clumps, $35 \mathrm{c}$ each.

RIBBON GRASS. Good strong clumps, $25 \mathrm{c}$ each; $\$ 2.00$ per dozen.

PURPLE LILAC An old-fashioned shrub which will each; $\$ 3.00$ per dozen.

NOVELTY SHRUB COLLECTION POST PAID FOR $\$ 1.50$

Six Choice Shrubs (Real Value \$2.10) Splendid Collection

I EUONYMOUS (Evergreen) - - - - - 35c

1 SNOWBERRY

I TAMARIX

1 BUTTERFLY BUSH - $\cdot \cdot \cdot \cdot \cdot-30 \mathrm{c}$

1 PUSSY WILLOW - $\cdot \cdot \cdot \cdot \cdot \cdot \cdot 40 c$

I RED TWIG DOGWOOD - - - - - - 35c

One Good Strong Plant of Each of Above by Parcel Post Prepaid Only $\$ 1.50$. This Collection Will Surely Please You. 


\section{Scarff's Beautiful Privet Hedge Plants}

The Privet is the most desirable hedge plant for the boundary of the lawn, along drives or to form an enclosure of any kind. The deep green glossy foliage hangs late in the fall and often well into the winter. The hedge adds a touch of privacy and formality to your home. The Privets are thrifty growers and will make a good thick hedge the first year after planting. They can be clipped to any shape.

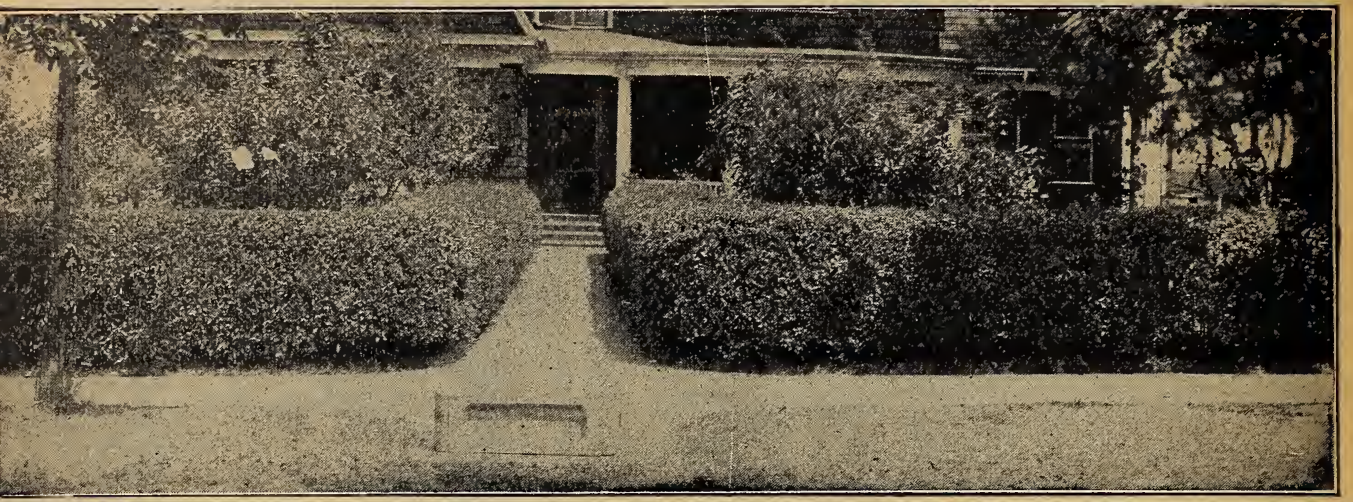

Californla Privet Hedge

CAIIFORNA PRIVETHEDGE One of the most beautiful plants for hedges in CALIFORNIA PRIVE HEDGE existence. There is no other hedge plant that nill equal the California Privet for the purpose, becoming more beautiful each year. A quick, strong growing shrub, yet easy to control by use of shears or knife to any desired shape. Fine for hedges between the city lots, on large rural grounds, parks, cemeteries, in single clumps with other shrubs, also as screens to outbuildings, fences, etc. Very easy to grow on all soils, even in partial shade; almost evergreen, its rich, leathery, green foliage turns to purple in winter. Prlce, $\$ 1.50$ per doz., by mall, postpaid. Heavy plants, by express, $\$ 6.00$ per $100 ; \$ 50.00$ per 1000 . Medium grade, $\$ 4.00$ per $100 ; \$ 30$ per 1000 .

AMOOR RIVER PRIVET This variety makes as beautiful a hedge as the California Privet and it has never winter-killed for us. Produces an oblong, glossy green foliage, half evergreen. Drops its leaves in early mid-winter. If allowed to grow untrimmed it produces beautiful clusters of white flowers followed by glossy black berries. Price, $\$ 2.00$ per dozen; $\$ 8.00$ per 100 .

IBOTA PRIVET This perfectly hardy privet is popular on account of its spreading habit. It

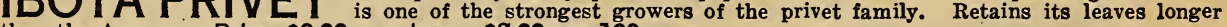
than the Amoor. Price, $\$ 2.00$ per dozen; $\$ 8.00$ per 100 .

IBOLIUM PRIVET (NEW) A cross between California Privet and Ibota, having the at an excellent hedge when trimmed. Price, $\$ 2.00$ per dozen; $\$ 8.00$ per 100 .

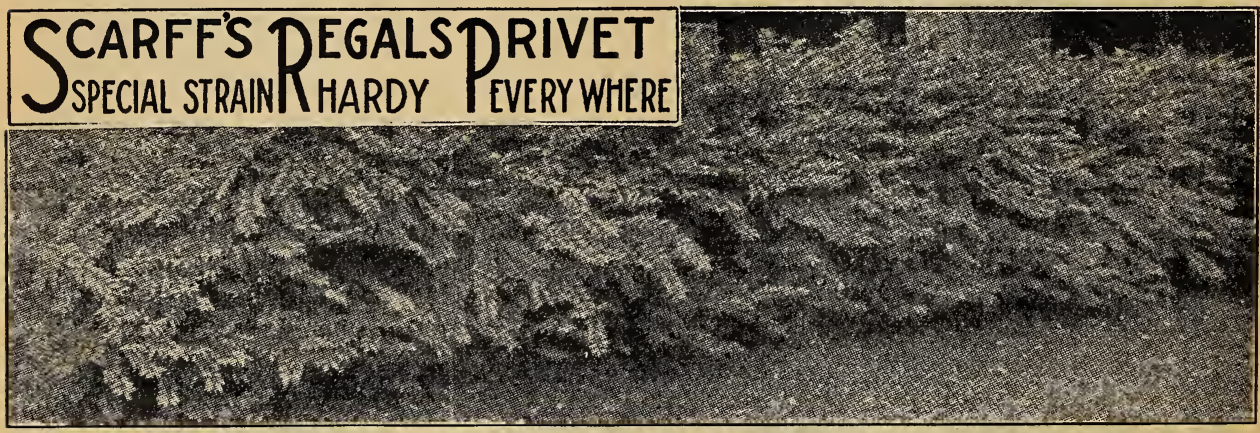

The Regel's Privet is hardy everywhere, and is one of the most attractive of the Privet family. The branches are graceful and run out horizontal from the main stem, leaves flat and drooping. A strong grower and especially fitted for division fence between lots or for front fence. A distinct and attractive type that is highly satisfactory. Price, 20c each; $\$ 2.00$ per dozen; $\$ 10.00$ per $100 ; \$ 80.00$ per 1000 .

\section{NEW CATALOG OF LANDSCAPE GARDENING}

We have issued a very fine catalog on landscape gardening and what to plant. It is well written and finely illustrated, and will be of great value to the planter and owners on fine estates. Sent free to persons interested in ornamental planting. We also give free to each customer a book on transplanting and care of trees, shrubs. etc. It is a valuable treatise. 


\section{E V E R G R E E N S}

These are the plants that will give your planting a striking green effect throughout the winter. The varieties we are offering are the hardy types that are good compact plants and are easy to transplant. Plant them in front of your porches, in foundation or group plantings. They will double the beauty of your planting.

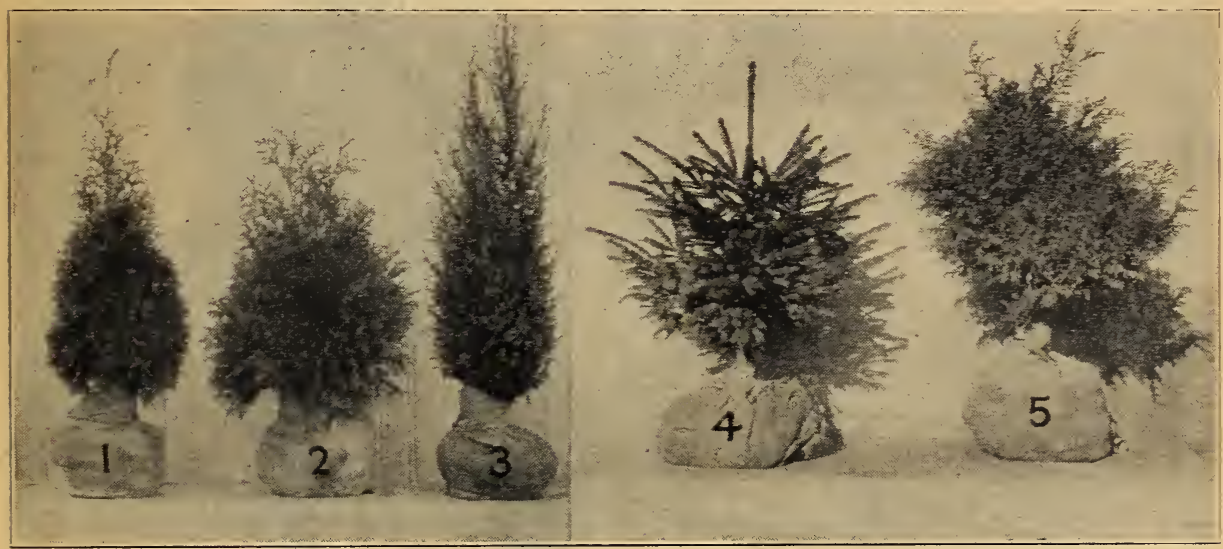

Numbers on Photograph Refer to Varieties Below.

PYRAMID ARBOR VITAE (1) A densely branched variety forming a perfect column; bolds Price, 3 ft. plants, $\$ 2.00$ each.

AMERICAN ARBOR VITAE (2) Strong, graceful habit of growth. Can be kept trimmed to for large group plantings. Price, 2 to $3 \mathrm{ft}$. plants, $\$ 1.50$ each.

IRISH JUNIPER (3) A very beautiful columnar form of Evergreen with upright growing branches. effect is silvery green. Excellent to use for accent planting; to place Price, $3-31 / 2$ ft. trees, $\$ 2.50$ each.

NORWAY SPRUCE (4) Branches horizontal; excellent for wind breaks. The smaller sizes are Price, 2 ft. plants, $\$ 1.25$ each.

used for foundation planting and kept down to desired size by trimming.

RETINOSPORA PLULMOSA (5) Graceful plumelike foliage, compact and an excellent other evergreens. Our field of these is very fine Evergreen for either foundation or planting in group with plants, $15-18$ inches in height for $\$ 1.75$ each.

CHINESE ARBOR VITAE (BIOTA) When young rather pyramidal in growth and as it becomes older assumes the habit of a rather loose growing cedar. Foliage is bright green turning to bronze in winter. Price, 18-24 in. trees, $\$ 1.00$ each. For porch boxes, 10 in. plants, $50 \mathrm{c}$ each.

GOLDEN ARBOR VITAE (GEO. PEABODY). beautiful golden color in sharp contrast to the deep green of other varieties. Price, 1 ft. plants, $\$ 1.25$ each.

DWARF BOXWOOD A hardy low growing type of edging and for low hedges. Price, $10-12$ in. plants, 350 each; $\$ 3.50$ per dozen.

YUCCA Vivid green sword shaped foliage as shown in UCCA illustration. Remains green all winter. Produces tall spikes of beautiful bell shaped flowers in August. Price, $25 \mathrm{c}$ each; $\$ 2.50$ per doz.

EUONYMUS RADICANS Holds its leaves until very late winter; valuable to plant in front of other shrubbery as edgeing; forms excellent low growing hedge if kept trimmed; can be trained to wall or chimney as a vine. Price, 300 each; $\$ 3.00$ per doz.

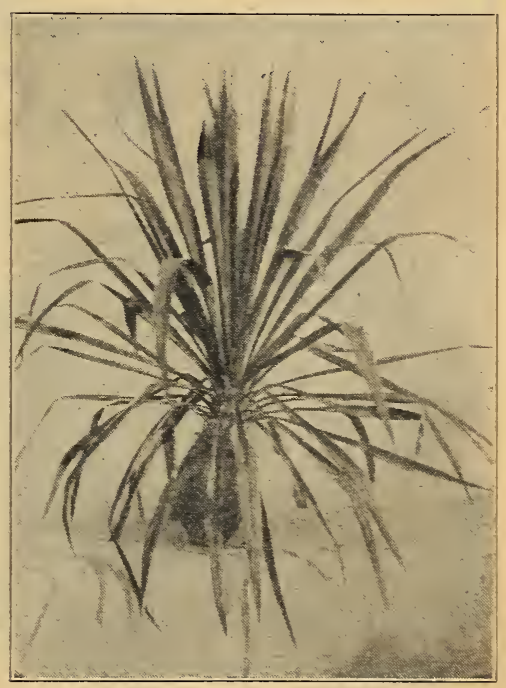




\section{Scarff's Superb Iris.}

The Iris is one of the easiest to grow of all the tloral family. They will thrive year after year with perfect abandon and neglect. At the same time they respond quickly to good soil and clean culture. Give them plenty of water during the blooming period, after that little or no water, except the natural rainfall is needed. They are perfectly hardy anywhere and can be planted at almost any season of the year. Spring and fall, however, is the best season for planting. They hloom during May and June.

FLORENTINE One of the earliest. Plant exceptionally thrifty and prolific in bloom. Leaves remain green most of the winter. Excellent for border plantings. Flowers large, rich violet-purple. Price, 20c each; $\$ 2.00$ per dozen.

CELESTE One of the finest varieties. Beautiful fragrant flowers, self-colored pale sky blue. Very profuse bloomer, tall habit. Price, $25 \mathrm{c}$ each; $\$ 2.50$ per dozen.

PALE YELLOW Dark tan color. Strong $\mathrm{g}$ r o w e r, profuse bloomer.

Price, 20c each; $\$ 2.00$ per dozen.
SIBERIAN IRIS Deepest blue. The most Iris elegant and delicate of the tiful green color. The flowers are clear deep blue and bloom in great profusion. A border of this variety or even a single clump commands the admiration and attention of everyone. No collection is complete without our beautiful strain of indigo-blue Siberian Iris. Price, 20c each; $\$ 2.00$ per dozen.

GRACCHUS Late, medium height. Stands Price, 20c each; $\$ 2.00$ per dozen.

SNOW QUEEN (SIBERIAN) Beautiful large stamens conspicuous in throat of bloom. Price, 25c each; $\$ 2.00$ per dozen.

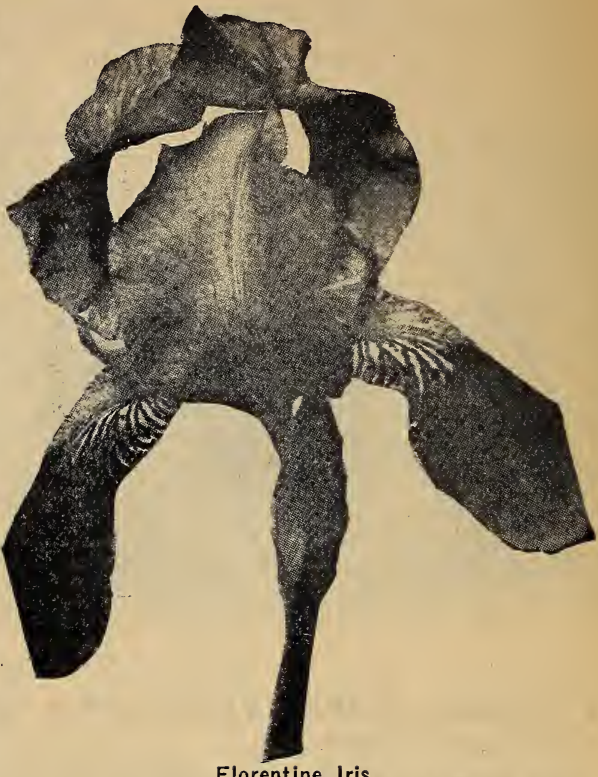

OSSIAN Canary yellow or straw color with light violet falls. Late blooming, medium height, strong, thrifty grower. Price, 25c each; $\$ 2.50$ per dozen.

SANS SOUCI_HONORABILIS An exceptionally fine variety. Medium tall, thrifty grower, - late. Stands are a clear orange yellow, falls are a deep wine. Very beautiful and highly prized. Price, $25 \mathrm{c}$ each; $\$ 2.50$ per dozen.

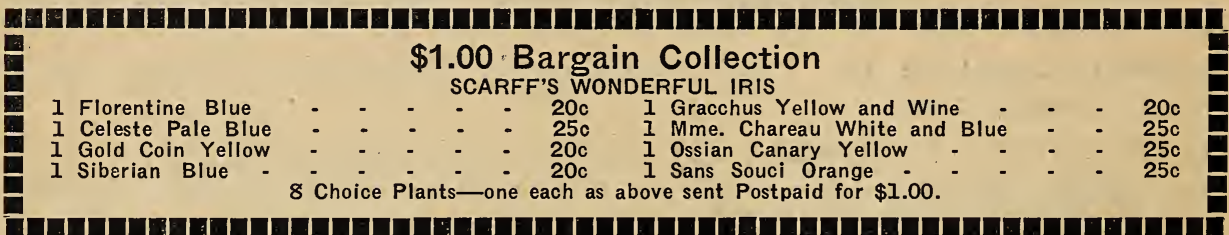
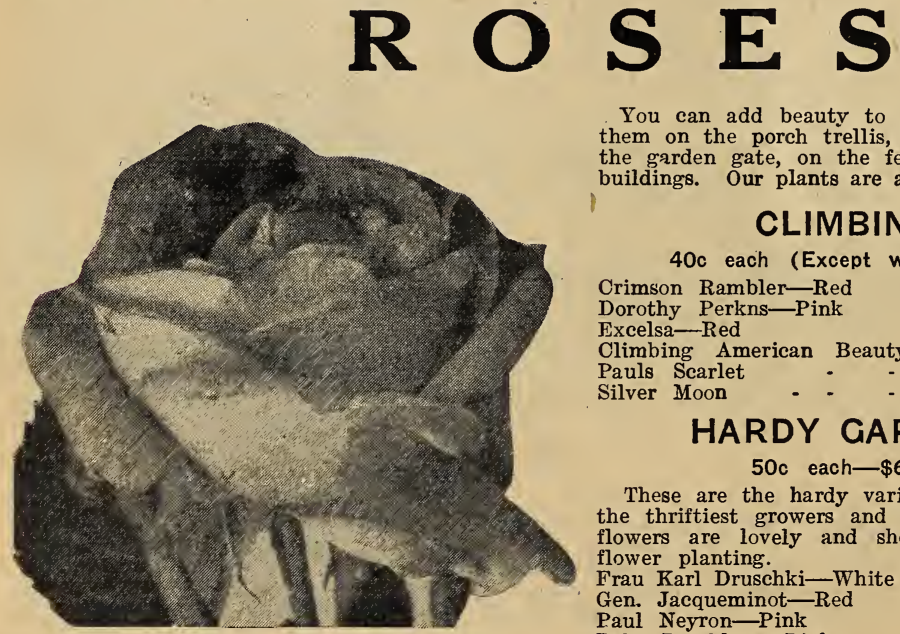

You can add beauty to the home with roses. Plant them on the porch trellis, plant them on the arch over the garden gate, on the fences and on the sides of the buildings. Our plants are all field-grown, blooming sizes.

\section{CLIMBING ROSES}

40c each (Except where otherwise noted.)

Crimson Rambler-Red

Dorothy Perkns-Pink

Excelsa-Red

Climbing American Beauty - - - $\$ .50$

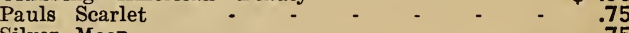

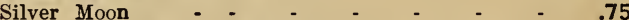

\section{HARDY GARDEN ROSES}

$50 \mathrm{c}$ each- $\$ 6.00$ per dozen.

These are the hardy varieties that have proven to be the thriftiest growers and most reliable bloomers. The flowers are lovely and should be in every garden or flower planting.

Frau Karl Druschki-White

Gen. Jacqueminot-Red

Paul Neyron-Pink 


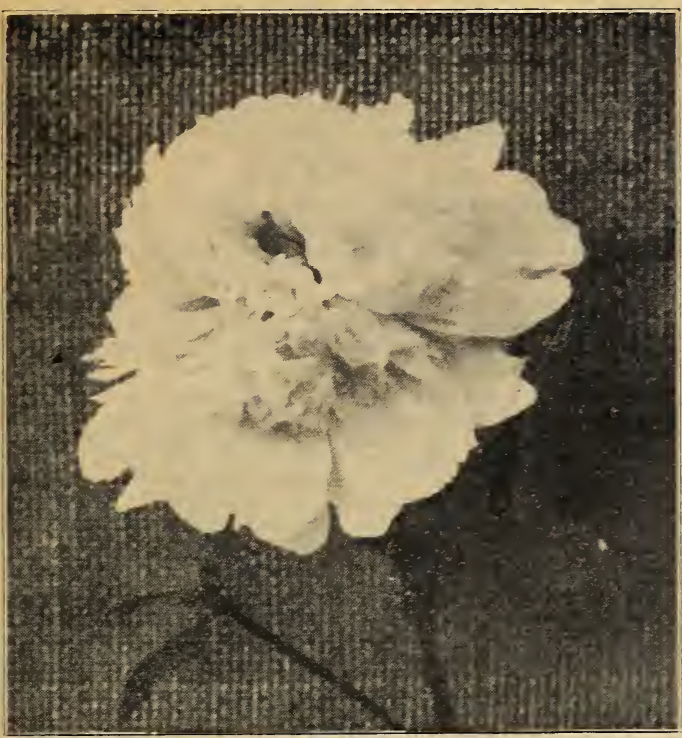

Festiva Maxima

\section{GLADIOLAS}

15c. Each; $\$ 1.50$ Per Dozen, Postpaid. WINE KING-Wine color. HALLEY - Salmon Pink. KIRTLAND-Rosy Pink.

LILY WHITE-White.

GRETZHEN ZANG-Pink and Scarlet.

ROANOKE-Yellow, red streaks.

MRS. FRANCIS KING-Flame color.

AMERICA - Lavender.

PANAMA-Rich Rose Pink.

LE MARSHAL FOCH-Apple Blossom Pink.

SCHWABEN-Pale Yellow.
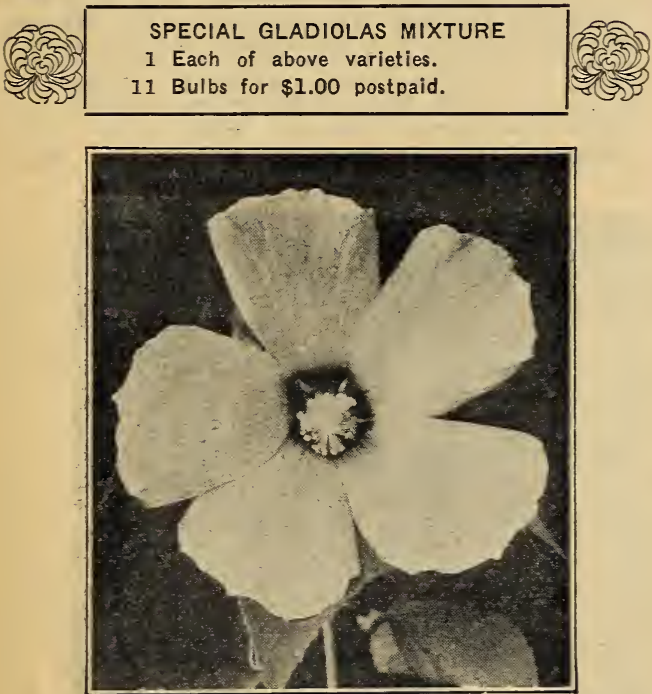

Mallow

NEW GIANT FLOWERING MARVEL MALLOW

The large, shown flowers of this new mallow average 5 to 6 inches in diameter. They start. blooming the latter part of July, when flowers are quite, scarce, and continue for aver a month. This is a perennial that is perfectly hardy and thrives in either wet or dry soils. We are sure you will like it. We can furnish this in three colors, white, pink, and red. Price, strong roots, 25c each; $\$ 2.00$ per dozen.

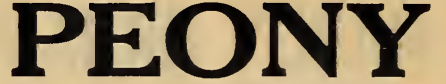

\section{Queen of Perennials}

FESTIVA MAXIMA. Very large, globular rose type. One of the largest white varieties, center flecked with crimson. Queen of all the peonies. Very tall, strong grower. Fine for cut flowers. Undoubtedly the most popular white in existence. Price, $50 \mathrm{c}$ each; $\$ 5.00$ per dozen.

FRAGRANS. Dark pink, medium size, compact and tall; fragrant, strong, vigorous grower. Price, $50 \mathrm{c}$ each; $\$ 5.00$ per dozen.

MADAME BUOUET. Large, loose semirose type. Very dark crimson amaranth. Coloring very rich. Plant medium height, free bloomer. Very attractive. Midseason. Price, $75 \mathrm{c}$ each; $\$ 8.00$ per dozen.

DUPONT. Ivory white, center splashed with carmine. Very fragrant; tall and free bloomer. Price, $50 \mathrm{c}$ each; $\$ 5.00$ per dozen.

MADAME CALOT. Flesh white tinted, fragrant; tall, strong grower, free bloomer. Early. Price, 50c each; $\$ 5.00$ per dozen.

MONS. JULES ELI. A most beautiful peony. Very large bloom with high crown. Color is a delicate shade of rose pink. Quite fragrant. Medium in height and a very strong grower. One of the finest of ail peonies. Price, $75 \mathrm{c}$ each; $\$ 7.50$ per dozen.

\begin{tabular}{|c|}
\hline SPECIAL PEONY OFFER \\
One each of above varieties-Value $\$ 3.50$ \\
6 Peonies $\$ 2.50$, Postpaid.
\end{tabular}

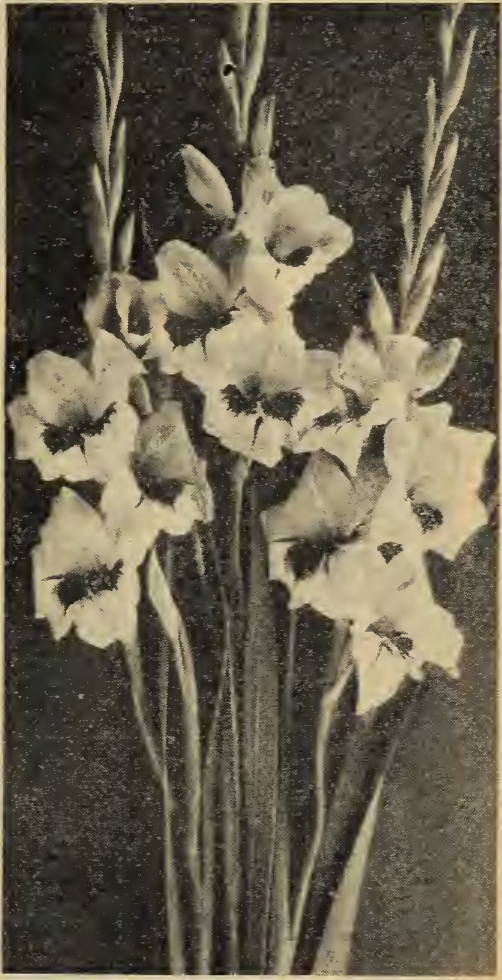

Gladiolas 


\section{HARDY ORNAMENTAL CLIMBING VINES}

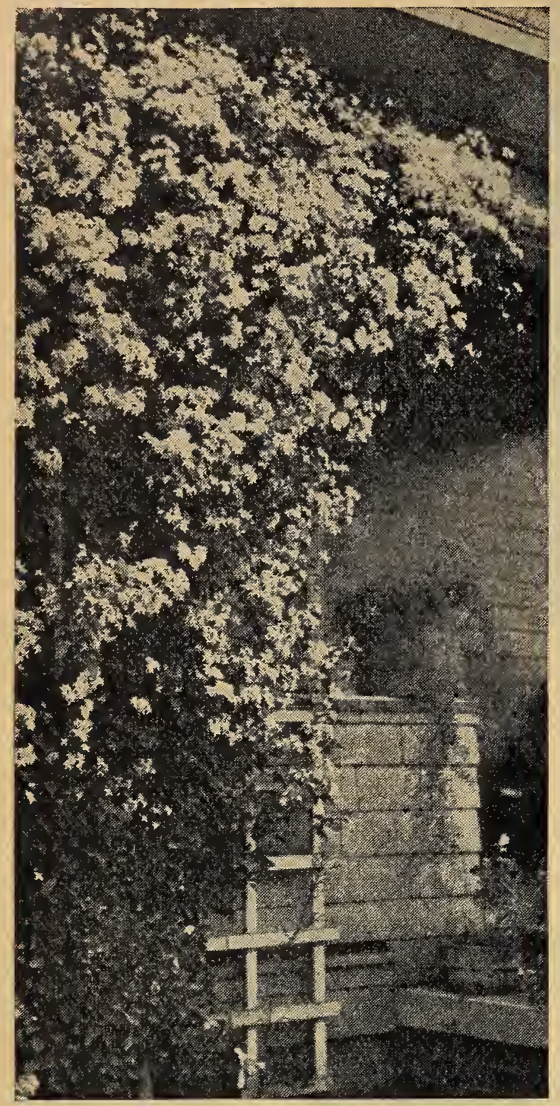

Clematis Paniculata
BOSTON IVY. The most desirable Ivy for chimneys, brick and stone walls. Leaves are glossy green, clings tight to any surface and forms an even carpet of green. Price, 50c each; 5 for $\$ 2.00$.

VIRGINIA CREEPER. Five-leaved Ivy. One of the best for wooden surfaces, to cover fences, posts, etc. Strong grower, hardy and a good climber. Price, 25c each; $\$ 2.00$ per doz.

CHINESE MATRIMONY VINE. Strong growing woody vine producing small purple flowers in midsummer and numerous orange-red fruits in the fall. Price, 25c each; $\$ 2.50$ per dozen.

CLEMATIS PANICULATA (Virgin's Bower). The finest of the small-flowered Clematis. In midsummer the entire vine is clothed in a mass of white bloom, followed by numerous light feathery seeds which are attractive until late in the winter. The vine is thrifty, hardy and a strong grower, and is very beautiful when grown intermingled with Honeysuckle. Price, $35 \mathrm{c}$ each; $\$ 3.50$ per doz.

CLEMATIS (Large-Flowering). 'We can furnish these in assorted varieties. Price, 50c each.

CLIMBING EUONYMUS (Evergreen). A hardy evergreen vine, very strong grower and perfectly hardy. Produces small white flowers. The vine requires a little supporting on hard, smooth surfaces. Very desirable to use on chimneys, walls, lattice or wherever an evergreen vine is desired. Often used in window boxes and porch boxes to furnish color during the winter months. When kept trimmed it forms a compact, low, bushy shrub, very attractive around the porch or foundation. Strong plants, 35c each; $\$ 3.00$ per dozen.

HONEYSUCKLE (Sweet Scented). A well-known almost evergreen vine, highly desirable for its beautiful glossy green foliage and for its fragrant flowers which are produced over a long period during the summer and are followed by jet black fruit which remains on the vine most of the winter. Plant them along the garden fence, along the side of the lawn or on the porch lattice. You will be delighted with their fragrance: Price, $25 \mathrm{c}$ each; $\$ 2.50 \mathrm{doz}$.

TRUMPET HONEYSUCKLE (Red). This is a very beautiful variety that retains its glossy green foliage practically all winter. Flowers are orange red, trumpet shaped, borne in clusters and holding on over quite a long period of the summer. Price, $35 \mathrm{c}$ each; $\$ 3.50$ per dozen.

TRUMPET FLOWER. From the old garden. Flowers perfect, trumpet-shaped, bright scarlet. A rapid grower; one of the finest vines for covering old stumps, fences, trellises, etc. Blooms almost continuously through the summer. Price, 25c each; $\$ 2.50$ per doz., postpaid.

PURPLE WISTARIA. 50c each; $\$ 5.00$ per doz.

CHINESE WHITE WISTARIA. Silvery white. Same price as Purple Wistária.

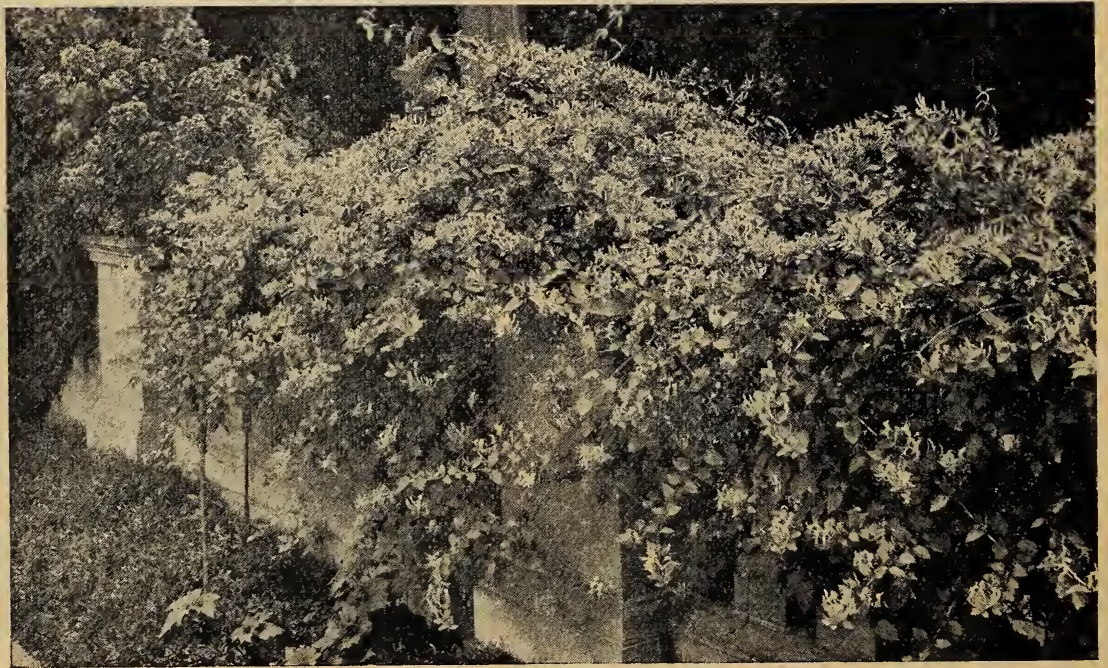




\section{Ornamental Trees}

NORWAY MAPLE The Norway Maple for the lawn and street planting has perhaps no equal. It Not a rapid grower, but it makes a compact and symmetrical top with shade trees. Price, good 8 to $10 \mathrm{ft}$. trees, $\$ 3.00$ each.

Ash, American White 8 to $10 \mathrm{ft}$

Catalpa, Speciosa, 8 to $10 \mathrm{ft}$

Catalpa Bungei, 2-year heads, 6 to 8 .

Dogwood. White Flowering, 6 to $8 \mathrm{ft}$.

Elm, American, 8 to $10 \mathrm{ft}$

White Birch, 5 to $6 \mathrm{ft}$..

Ailanthus (Tree of Heaven), 4 to $5 \mathrm{ft}$

Maple, Ash-Leaved, 8 to $10 \mathrm{ft}$.

Maple, Norway, 8 to $10 \mathrm{ft}$

Map!e, Sugar, 8 to $10 \mathrm{ft}$

Poplar, Carolina, 8 to $10 \mathrm{ft}$.

Poolar, Lombard, 8 to $10 \mathrm{ft}$

Poplar, Norway, 8 to $10 \mathrm{ft}$.

Poplar, Volga, 8 to $10 \mathrm{ft}$.

Horse Chestnut, 5 to $6 \mathrm{ft}$

Bechtel's Flowering Crab

Willow, "Pussy Willow" 5 to $6 \mathrm{ft}$

Beech, Purple Leaf

Sassafras, 4 to $5 \mathrm{ft}$.

Mulberry, Teas' Weeping 2-rear heads

Mulberry, Russian, 5 to 6 ft.

Mulberry, New American.

Black Walnut, $6 \mathrm{ft}$.

Paw Paw

Persimmon

Butternut, 10 to $12 \mathrm{ft}$

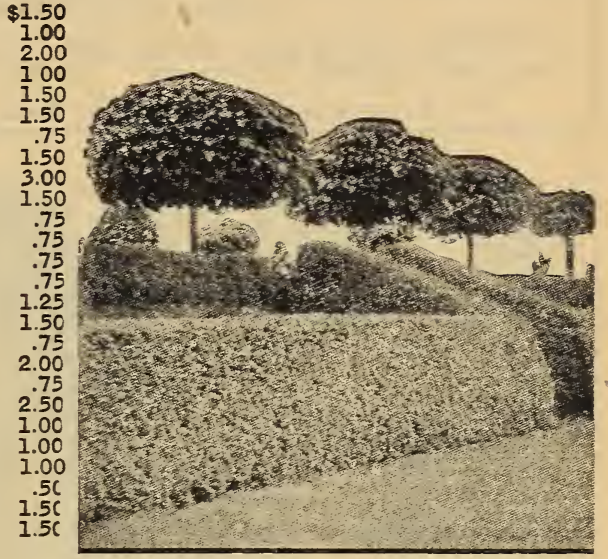

Catalpa Bungei Trees

AMERICAN ELM (Ulmus Americana) This well-known tree ranks among the very best for avenue or park, especially in deep or wet seil. It grows rapidly and makes tough branches, rarely being damaged by wind or snow. Its spreading head, drooping branches and stately growth, give it the name of the "Monarch of the Forest." Price, 8 to $10 \mathrm{ft.,} \$ 1.50$ each.

NORWAY POPLAR This variety has just come into prominence lately because of its marked superiority over the other similar varieties of this family of trees. It grows very rapidly and has been known to attain a height of 50 feet with a diameter of 17 inches in 14 years. Growth is tall and straight, makes a good shade, retaining its leaves until late in autumn, and on account of the rapid growth it makes an excellent wind break. The wood is straight grained and suitable for lumber. Splits easily, seasons quickly and makes excellent fuel. Price, 8 to $10 \mathrm{ft.,} 75 \mathrm{c}$ each.

CATALPA BUNGEI (Umbrella Catalpa) Grafted on stems 6 to 8 feet high, it makes an umbrella. shaped top without pruning. Perfectly hardy, and flourishes in almost all soils and climates. Leaves large, glossy, heart-shaped, deep green; lie like shingles on a roof; always making a symmetrical shade. One of the most unique trees, a valuable acquisition for lawn, park and cemetery planting. Price, 6 to $8 \mathrm{ft}$., $\$ 2.00$ each.

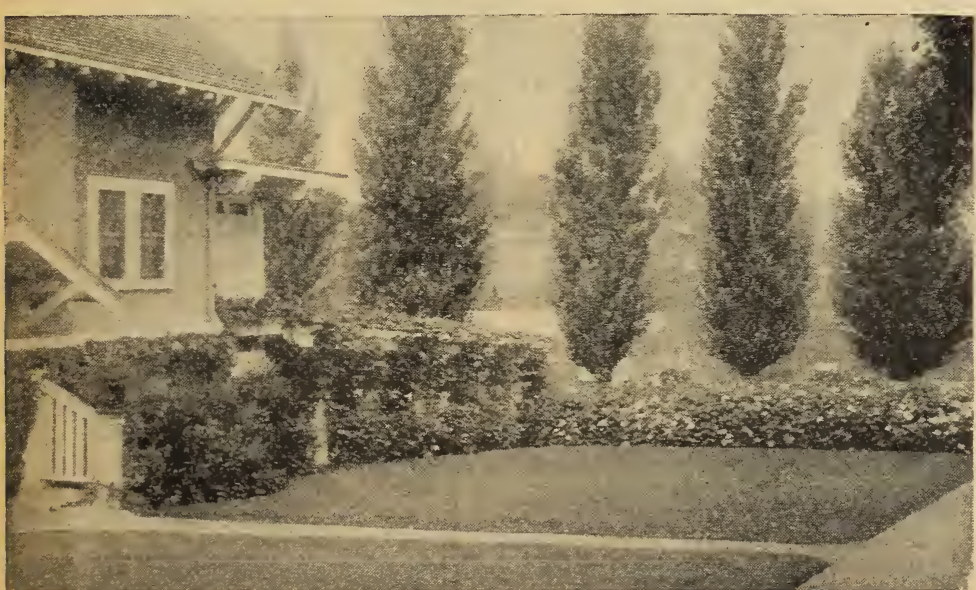

A Good Shrubbery Planting-Volga Poplar Trees in Background.

\section{Volga Poplar}

Upright in growth, valuable for planting along driveways, boundary lines, in the background and as a screen. The accompanying photograph illustrates very plainly the beauty of the Volga Poplar. It is a very rapid grow. ing tree and will furnish almost im mediate effect. The Poplar are the best trees to plant with the slower growing kinds. Their rapid growth will furnish quick shade and as the permanent trees attain good size the Poplar may be removed. Fine trees, 6 to $8 \mathrm{ft}$. Price, $75 \mathrm{c}$ each. 


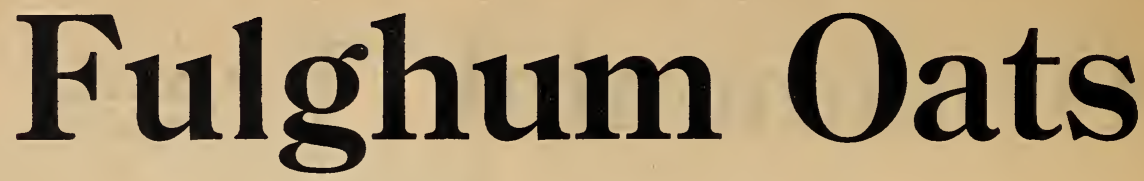

MAKES NEW RECORD FOR 1925

\subsection{BUSHELS PER ACRE \\ HIGHEST YIELD ON RECORD IN OUR COUNTY}

Gentlemen:-

In reply would say the yield was $742 \frac{1}{2}$ bushels off 7.39 acres. Same was in corn last year, hogged off. No other fertilizer used.

Weights and measurements verified by County Agent. CLARENCE J. BUTCHER.

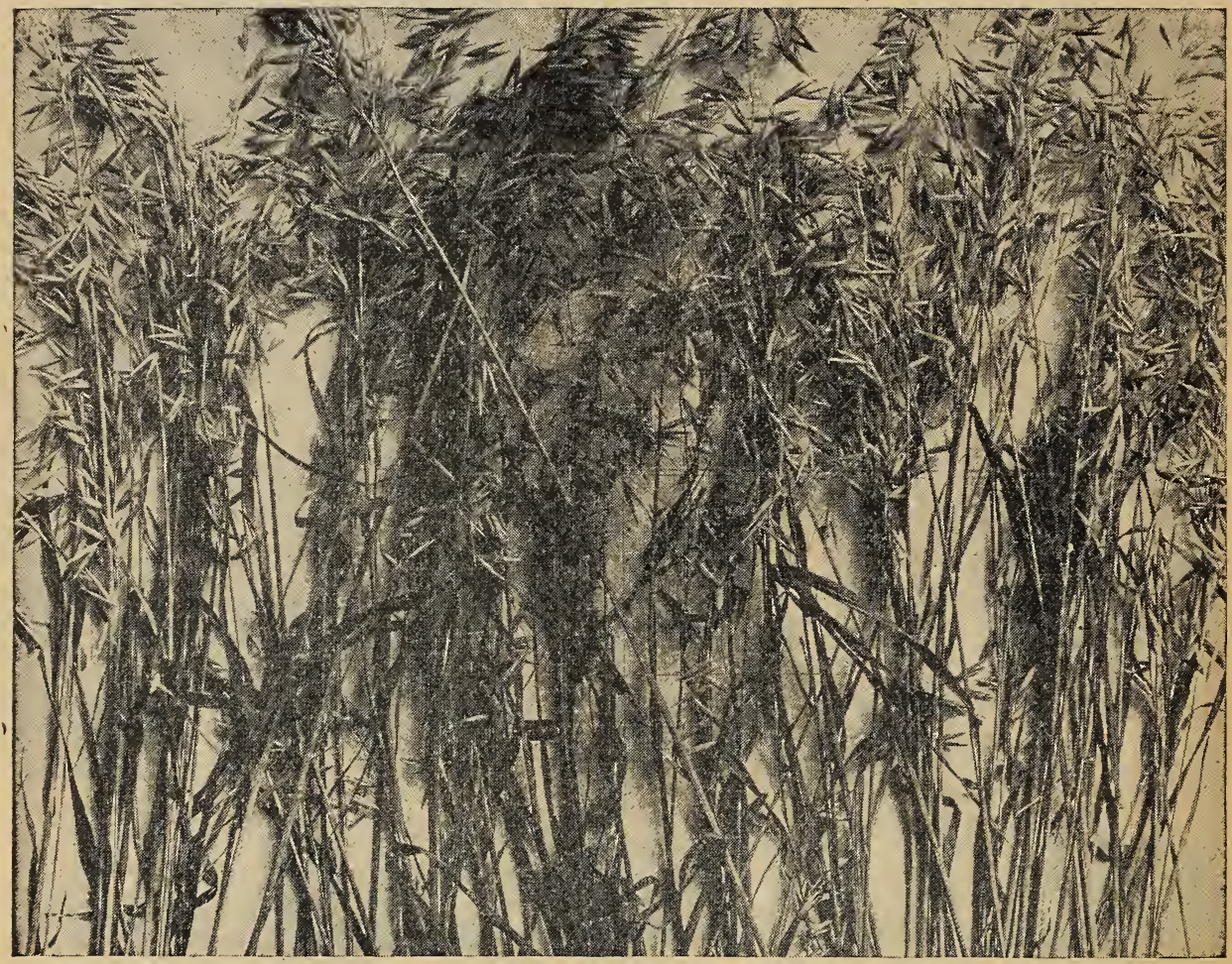

DESCRIPTION-The Fulghum is a strain of awnless red oats, matures very early and is the heaviest vielder of any variety we know. In a nine-year test at the Ohio State University the Fulghum outyielded the best of the thirteen varieties tested by 8 to 10 bushels per acre. The straw is stiff, much taller than the average and produces a good crop in dry and adverse seasons when other varieties are practically a failure.

Productiveness, probably more than any of its other good qualities, has contributed to the wide popularity it has attained. We have reports of crops of from 70 to 94 bushels to the acre, a yield that any other oat will find it hard to beat. They stool out splendidly, have large, full heads, fine plump grains and strong straw

"FULGHUM 12 BUSHELS ABOVE THE AVERAGE

Dear Mr. Scarff:IN CLARK COUNTY"

During the year 1925 there were approximately one hundred crops of Fulghum oats grown in Clark County. We believe Fulghum yields are at least 12 bushels per acre above the county average yield of oats. The highest yield reported from our county was 100.4 bushels per acre.

We have grown Fulghum oats in Clark County for four years and the results have been very satisfactory every year. It is the best variety for our climatic conditions that we have been able to obtain. It ripens early, stands up well, and matures a plump, heavy grain. It is excellent for an alfalfa nurse crop.

Yours truly,

E. W. HAWKINS, County Agent.

\section{Fulghum Oats}

Best nurse crop for Clover, Alfalfa and other grass crops. It ripens with wheat and comes off the ground two weeks before ordinary Oats so the grass gets a good start before the dry weather and hot sun of July. For high yield and early maturing Fulghum has no equal. 


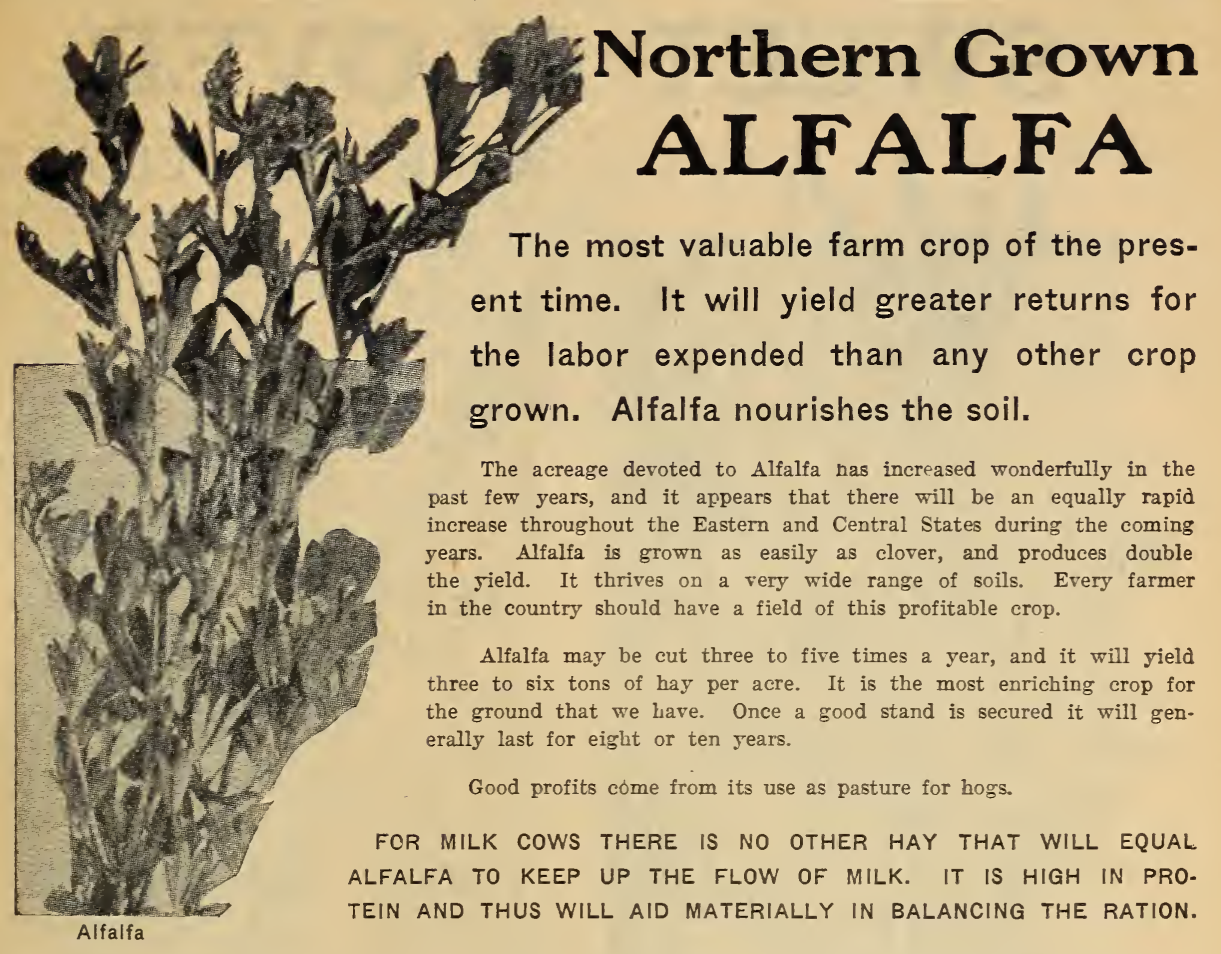

Alfalfa is one of the most profitable farm crops for three reasons: The tonnage per acre which it produces, its value as a feeding crop, and its soil enriching properties. Alfalfa is no longer an experiment, but it has been grown under greatly varying conditions of soil and climate.

Sample seed mailed free of charge if interested and you wish to buy. Price, peck, $\$ 4.00 ; \$ 15$ per bu. Prices subject to market change.

\section{Scarff's Genuine Northern Grown Grimm Alfalfa}

Grimm alfalfa is an extremely hardy strain that resists winter killing to a remarkable degree. In the northern sections of the country winter killing of alfalfa is a serious handicap to its successful cultivation. Farmers, as they become better acquainted with Grimm alfalfa and its advantages over common strains, are realizing that for permanent results Grimm, even at a higher cost for seed, is the most economical in the outcome.

\section{SOME FACTS ABOUT GRIMM ALFALFA}

1. It is positively the hardiest alfalfa seed on the market. (See Government Bulletin No. 209, Bureau of Plant Industry, page 21.)

2. The strong branching roots of Grimm prevent winter killing as in common ordinary alfalfa.

3. These same roots, which grow in time 6 to 20 feet in length and as thick as a man's wrist, provide DROUGHT RESISTANCE, and unusual productiveness.

4. Again these great roots make humus when ploughed into the soil, and this humus conserves moisture, thus preparing the soil for whatever subsequent crop might call for it.

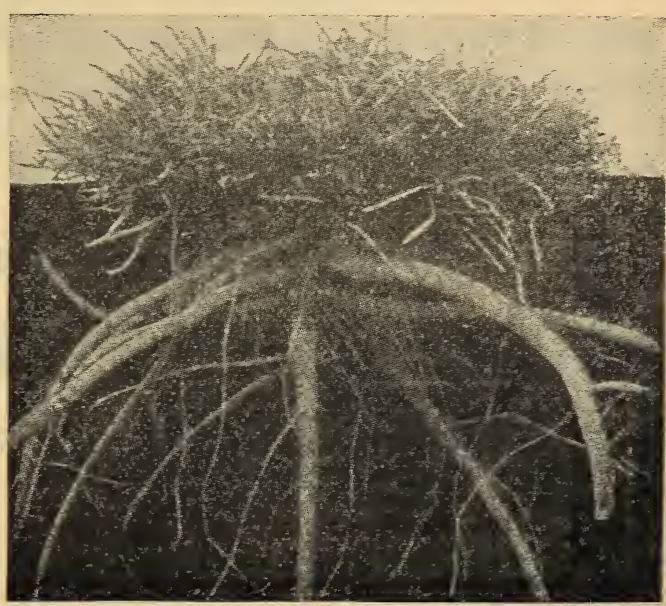

Grimm Alfalfa 5. Grimm Alfalfa plants are extraordinary soil fertilizers, capable of transforming the free nitrogen of the air into soluble nitrates through agency of the nodule-forming bacteria on the roots.

Price, Genuine Grimm Alfalfa Seed: Pkt., 25 cents; 1 lb., 65c; 5 lbs.. \$3.00, postpaid. Pk., \$7.50; bu., \$25.00. Price subject to change. Send for spot cash price and samples. 

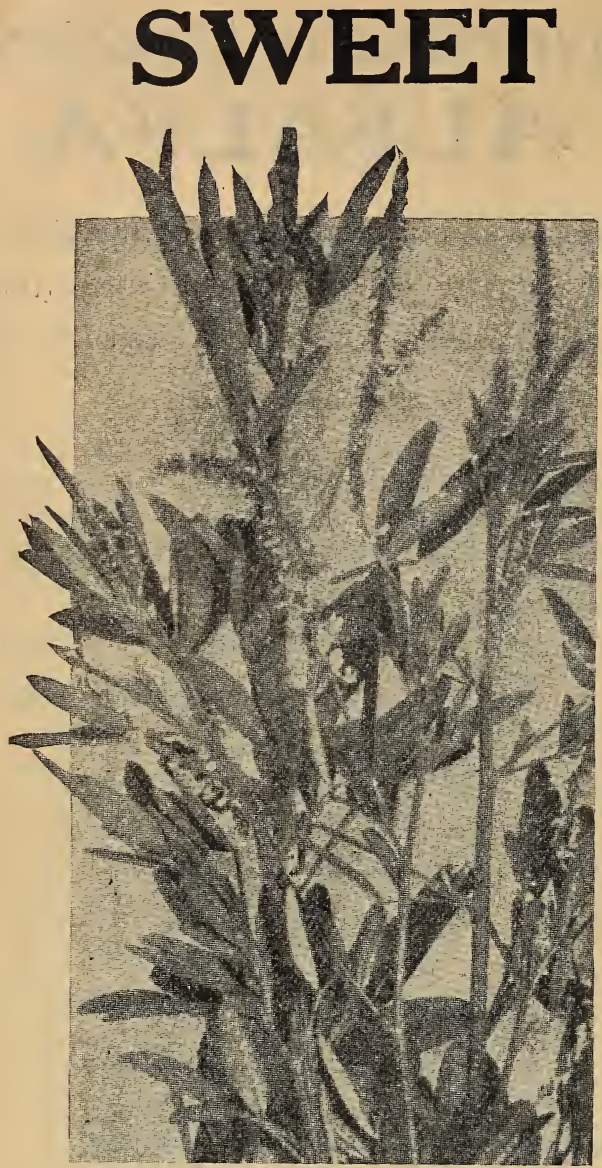

White Sweet Clover

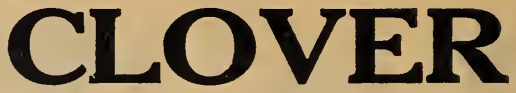

\section{WHITE SWEET CLOVER}

Sweet clover will grow in any part of the United States. It will thrive on the poorest sandy soil where no other kind will grow. Within the last few years, only. has its worth been recognized. Sweet Clover ranks first of all the clover as a fertilizer. Live stock soon develop taste for it and prefer it to other hay. Sweet clover sown in spring on well prepared seed bed can be cut for hay the same fall. Can be pastured the next spring or cut just before it blossoms for hay and again at later date. It can be sown during August and early September and will yield a full crop of hay next May. Too much cannot be said in its favor and we especially urge our customers to give it a trial at least. It will be to your benefit. We have found its worth and do not hesitate to recommend it to you. Sow 15 to 20 lbs. per acre. Price, peck, $\$ 2.75 ; \$ 10.50$ per bushel hulled seed. Subject to market change.

\section{YELLOW BLOSSOM SWEET CLOVER}

A biennial quite similar to the White Sweet Clover except that the growth is not quite so strong, the stems are finer and a more abundant supply of leaves are produced, thus making a higher grade old hay. Sown and handled same as White Blossom. Prioe, $\$ 3.00$ per peck; $\$ 11.50$ per bushel.

\section{WRITE FOR SPECIAL PRICES ON RED CLOVER}

\section{DWARF ESSEX RAPE}

Dwalf Essex Rape is a pasture plant for all kinds of live stock-sheep, cattle, and swine; and is most valuable for fattening sheep. It should be sown early in spring. As it grows very rapidly, the pasture will be ready in five weeks from the time of sowing. Unlike other forage plants, rape can be sown at any time during spring and summer, so a good pasture may be had whenever it is needed. Dwarf Essex Rape will prepare sheep and hogs for market better and in less time than any other forage plant.

It may be sown in corn when this is cultivated the last time. Good results are generally obtained for late fall pasture when Dwarf Essex Rape is sown after the spring grain has been harvested. When sown broadcast, 5 to 6 pounds may be sown per acre. Price, pound, postpaid, $25 \mathrm{c}$; prepaid. 10 pounds, $\$ 1.50$; 100 Ibs., $\$ 12.00$, by express, not prepaid. Subject to market change. Write for special price and sample.

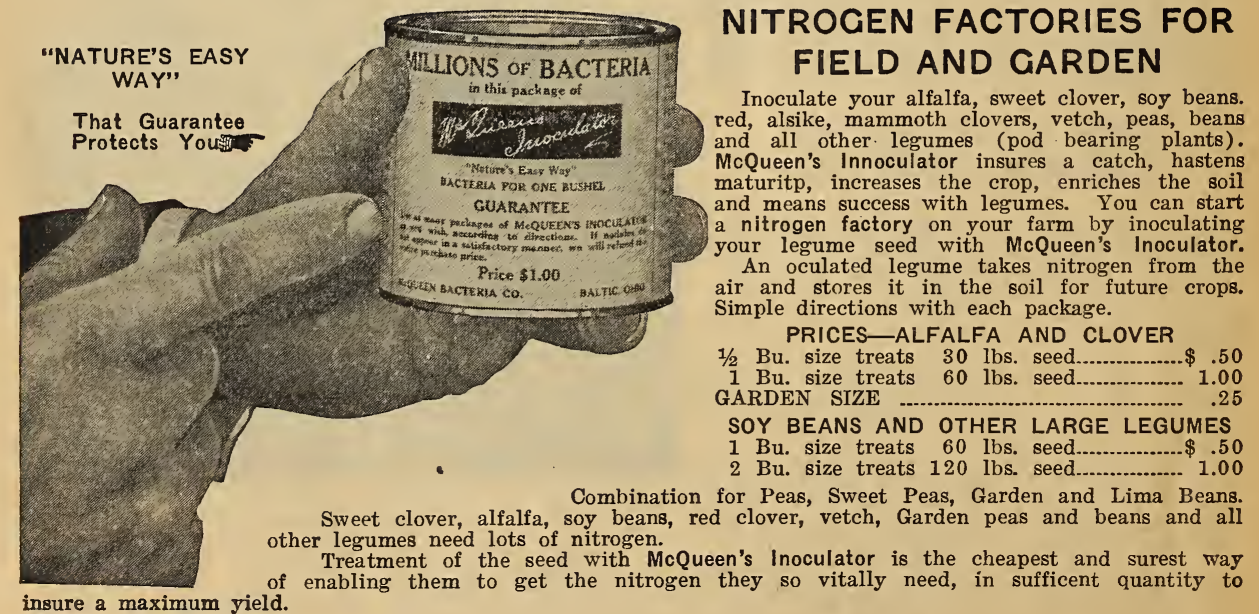



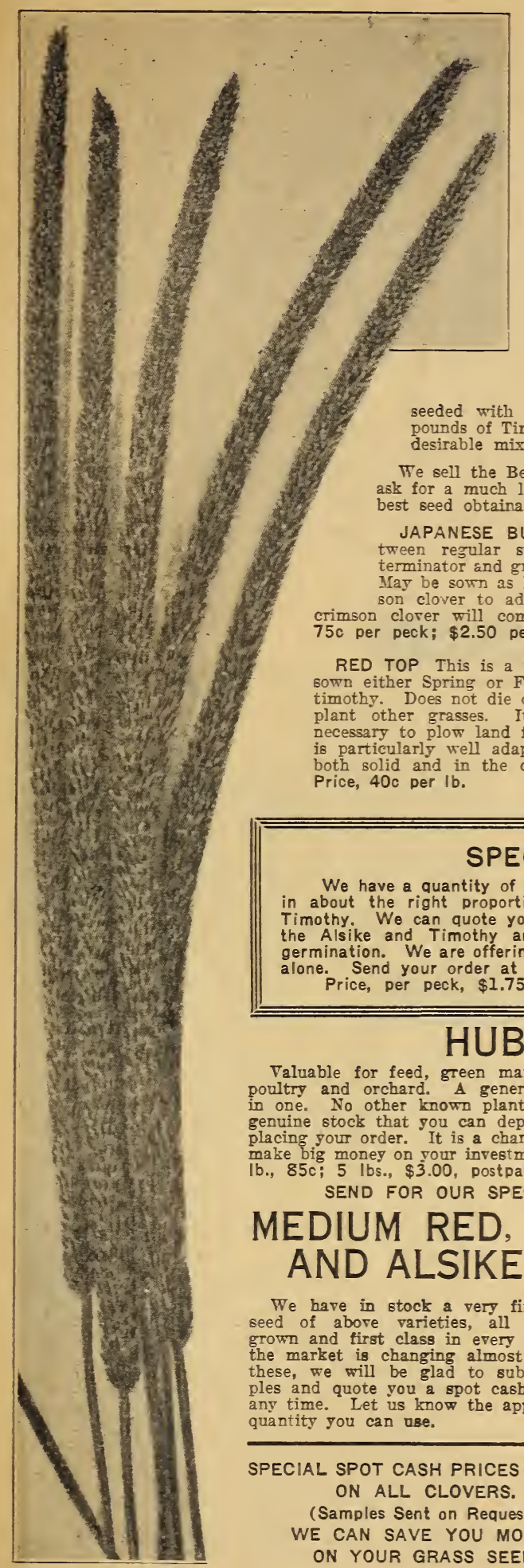

WRITE FOR SPECIAL PRICES ON TIMOTHY AND OTHER SEED

Timothy is the standard hay of commerce. The cheapness of the seed, the ease of culture, and excellent quality of the hay make it a favorite.

SOIL-It is adapted to all soils, but succeeds best on moist loams and clays. The life of a Timothy meadow varies according to soil and climate. It produces more profitable yields the first and second years.

Seeding-Timothy is grown in a four or five-year rotation; fifteen pounds of Timothy is considered a full seeding when used alone; when seeded with Clover, Wheat, Oats or Barlev, eight to twelve pounds of Timothr with four to five pounds of Red Clover is a desirable mixture.

We sell the Best Grade of Timothy Seed as low as many dealers ask for a much lower grade. If you grow hay you want only the best seed obtainable. Price, peck, $\$ 1.25 ; \$ 3.75$ per bushel.

JAPANESE BUCKWHEAT is a "catch crop" easily grown between regular succession crops. Aiso valuable as a weed exterminator and green manure. Makes the genuine Buckwheat Flour. May be sown as late as September 1st. It can be sown with crim. son clover to advantage. The buckwheat will die down and the crimson clorer will come on and make a splendid spring crop. Price, $75 \mathrm{c}$ per peck; $\$ 2.50$ per bushel. 5 bushels or more, $\$ 2.40$ per bushel.

RED TOP This is a valuable grass for either hay or pasture. May be sown either Spring or Fall. Grows slowly in the Spring but ripens with timothy. Does not die out. When once well started will spread and sup. plant other grasses. It, however, is not hard to destroy when it is necessary to plow land for other crops. It succeeds well in any soil and is particularly well adapted for low, moist lands. Red Top seed is sold both solid and in the chaff. Sow 8 to 10 lbs. per acre oi solid seed. Price, $40 \mathrm{c}$ per Ib.

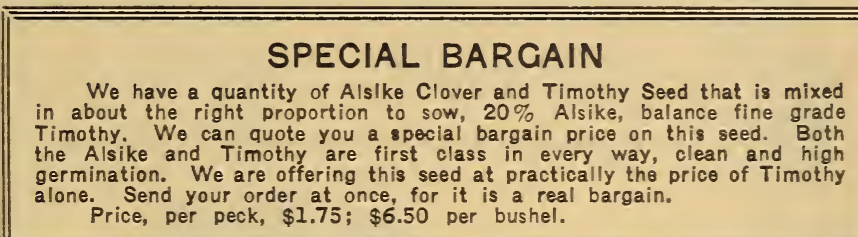

\section{HUBAM CLOVER}

Valuable for feed, green manure, bee pasture, stock grazing, ensilage, seed, poultry and orchard. A general purpose plant that completes a two-year job in one. No other known plant equals it in real value. Our supply of seed is genuine stock that you can depend upon. Do not let another day pass without placing your order. It is a chance of a lifetime to do good and at the same time make big money on your investment. Prices may advance. Price large pkt., $25 \mathrm{c}$; lb., 85c; 5 lbs., $\$ 3.00$, postpaid. Peck, $\$ 6.00$; bushel, $\$ 20.00$.

SEND FOR OUR SPECIAL CIRCULAR ON HUBAM CLOVER

\section{MEDIUM RED, MAMMOTH AND ALSIKE CLOVER}

We have in stock a very fine lot of seed of above varieties, all American grown and first class in every way. As the market is changing almost daily on these, we will be glad to submit sam. ples and quote you a spot cash price at any time. Let us know the approximate quantity you can use.

SPECIAL SPOT CASH PRICES QUOTED ON ALL CLOVERS.

(Samples Sent on Request)

WE CAN SAVE YOU MONEY

ON YOUR GRASS SEED.

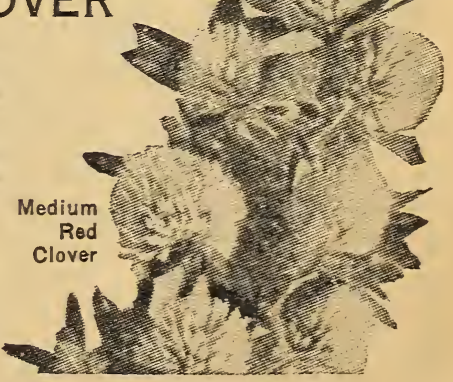




\section{SOY BEANS}

The Soy Bean is now recognized as one of the best paying farm crops. It is rapidly taking the place of wheat as it will make double the returns per acre when grown for either hay or seed. If grown for hay it will yield $1 \frac{1}{2}$ to $2 \frac{1 / 2}{2}$ tons per acre and it is equal in feeding value to the best of Clover or Alfalfa. When planted for grain the yield is 20 to 30 bushels per acre and if taken for feed the crop value is $\$ 40.00$ to $\$ 50.00$ per acre; besides, it is a legume and it is building up the soil just the same as clover and Alfalfa. It is also planted with corn, using three or four beans to each hill and put in the silo with the corn, or hogged down with wonderful results. The tonnage and yield of the corn crop is very materially increased and, strange to say, the corn yields even better with beans than where no beans are planted, as the Nitrogen on the roots of the beans is utilized by the grow. ing corn for growth of stock and grain. The seed is comparatively cheap and should be planted in every corn field and on every idle acre on the farm.

USES-The seed of the Soy Bean is very rich in protein and oil, but containing no starch; as a feed it occupies the same place as cotton-seed meal and oil meal. In feeding experiments at different Experimental Stations, Soy Bean meal has given results equal to either oil meal or cottonseed meal and, in some instances, even better results have been experienced. These high protein concentrates are necessary in all successful stock feding, especially so in milk production and in the feeding of immature animals. Growing the Soy Bean will enable the farmer and feeder to produce at least part of the required quantity at a moderate cost.

ITO SAN IThe Ito San is one of the oldest varieties of Soy Beans in common use today. It is a yellow1 Iseeded variety of a branching type, grows 28 to 40 inches tall and ripens seed in 95 to 100 days. This variety, though not as high a yielder of seeds as resistant to shattering as the Manchu, may be used for hogging-down with corn in latitudes similar to. Northern Ohio. Though making a rather light tonnage, the Ito San is recommended for early hay by many. Price, peck, $\$ 1.00$; bushel, $\$ 3.00$.

MEDIUM GREEN A popular variety in many sections. The seed is medium size, green in color, and is a high yielder. The seed shatters in harvesting, and is better for hoggingdown than for seed purposes. It makes an exceptionally uniform growth; has good foliage, which it holds up well to the time the seed is maturing, and it yields a splendid crop of seed. Price, peck, $\$ 1.50 ;$ bushel, $\$ 5.00$. MANCHU A promising variety that is making good wherever planted. It is one of the highest yielders of seed, grows erect from 36 to 48 inches tall and carries an abundance of foliage which it sheds almost perfectly when ripe. The Manchu has medium sized seed of a yellow color with a black or brown seed-scar. It matures in 100 to 105 days and is one of the most resistant varieties to shattering. It is unexcelled as a variety to plant with corn for hogging-down when corn of 100 to 120 days maturity is used. Price, peck, $\$ 1.00$; bushel, $\$ 3.50$.
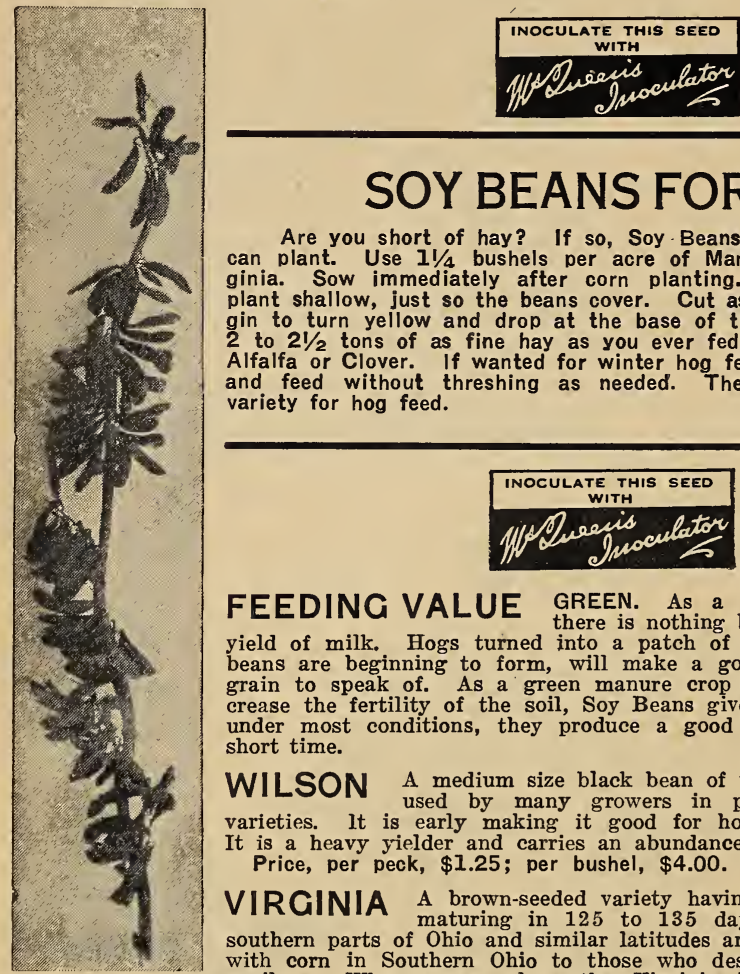

\section{SOY BEANS FOR HAY}

Are you short of hay? If so, Soy. Beans is the surest crop you can plant. Use $11 / 4$ bushels per acre of Manchu, Mid West or Virginia. Sow immediately after corn planting. Use wheat drill and plant shallow, just so the beans cover. Cut as soon as the leaves begin to turn yellow and drop at the base of the plant. You will get 2 to $21 / 2$ tons of as fine hay as you ever fed. Equal to the best of Alfalfa or Clover. If wanted for winter hog feed allow beans to ripen and feed without threshing as needed. The Ito San is the best variety for hog feed.

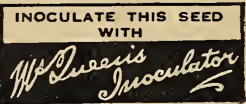

FEEDING VALUE GREEN. As a soiling crop for cows, FEE there is nothing better to produce a high yield of milk. Hogs turned into a patch of Soy Beans, just as the beans are beginning to form, will make a good growth without any grain to speak of. As a green manure crop to plough under to increase the fertility of the soil, Soy Beans give good satisfaction, for, under most conditions, they produce a good growth in a relatively short time.

WILSON A medium size black bean of unusual qualities. It is varieties. It used by many growers in preference to all other It is a heavy yielder and carries an abundance of foliage.

Price, per peck, $\$ 1.25$; per bushel, $\$ 4.00$.

VIRGINIA A brown-seeded variety having a twinning tendency, maturing in 125 to 135 days, adapting it only to southern parts of Ohio and similar latitudes and recommended for use with corn in Southern Ohio to those who desire a twining bean for ensilage. When grown alone the Virginia lodges and intertwines,

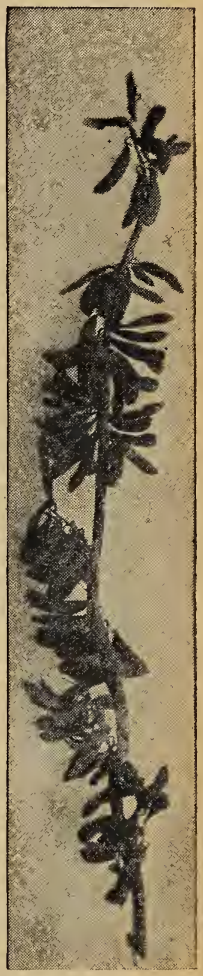
making it difficult to harvest or cure. Price, peck, $\$ 1.25$; bushel, $\$ 3.00$.

Write for Special Spot Cash Price on Soy Beans when ready to buy and we will quote you lowest market price. IMPORTANT-Be sure to inoculate all Soy Bean Seed. It will double your results.

\section{SEED POTATOES}

We are in position to save you money on your seed potatoes both on certified and ordinary seed. We can supply Early Ohio, Irish Cobbler, Petosky and Seneca Beauty, which are the very best varieties to plant for heavy yields.

Special prices quoted on seed potatoes in proper season. 


\section{BEARDLESS BARLEY}

This is a great stock food and fat producer. Is best egg-producing food known.

Straw about the height of common barley, but is stiffer, and will stand up on any land. With good land and season it has produced 80 bushels per acre. Sow as early as you can: frost does not hurt it. Many will not grow barley on account of the long, harsh beards which are so disagreeable in threshing, although it is a profitable crop. This is beardless and easy to grow and handle as oats. It has hulls like the Manshury or any other variety, and is a heavy cropper, yielding 50 to 75 bushels per acre, and the quality is excellent, both for maturing and for feeding
hogs and other stock. Try it for your poultry. Price, 75c per peck; $\$ 2.00$ per bushel.

Wisconsin Pedigreed Spring Barley

The best of the bearded spring varieties of Barley. It has won more prizes than all other varieties combined. The average yield in Wisconsin for the last five years has been $361 / 2$ bushels. It has a plump grain, stiff straw, large, well-filled heads... It has won prizes at all International Shows of recent years.

The following are reasons why "Wisconsin Pedigree Barley" is of such great value: Wisconsin for 5 years was 22 per cent above the yield of all other barley. Many yields of 50 bushels per acre and over have been reported and some as high as 75 bushels. Second-Plumpness of Grain. All who have grown it notice the unusually plump kernels.

Third-Stiffness of Straw. Stands up better than Oderbrucker or Mandschueri.

Fourth-Vigor of Growth. Taller than any other barley. We have measured plants five feet high.

Fifth-Uniformity. All the kernels are alike, an important matter with barley.

Sixth-Perfect Development. Heads are more com. pletely filled out than with any other variety.

Seventh-Large Heads. Many speak of the unusually long, large heads. Price, $50 \mathrm{c}$ per pk.; $\$ 1.25$ per bu. Nurse Crop for Alfalfa

The Spring Barley, including Beardless, White Hulless
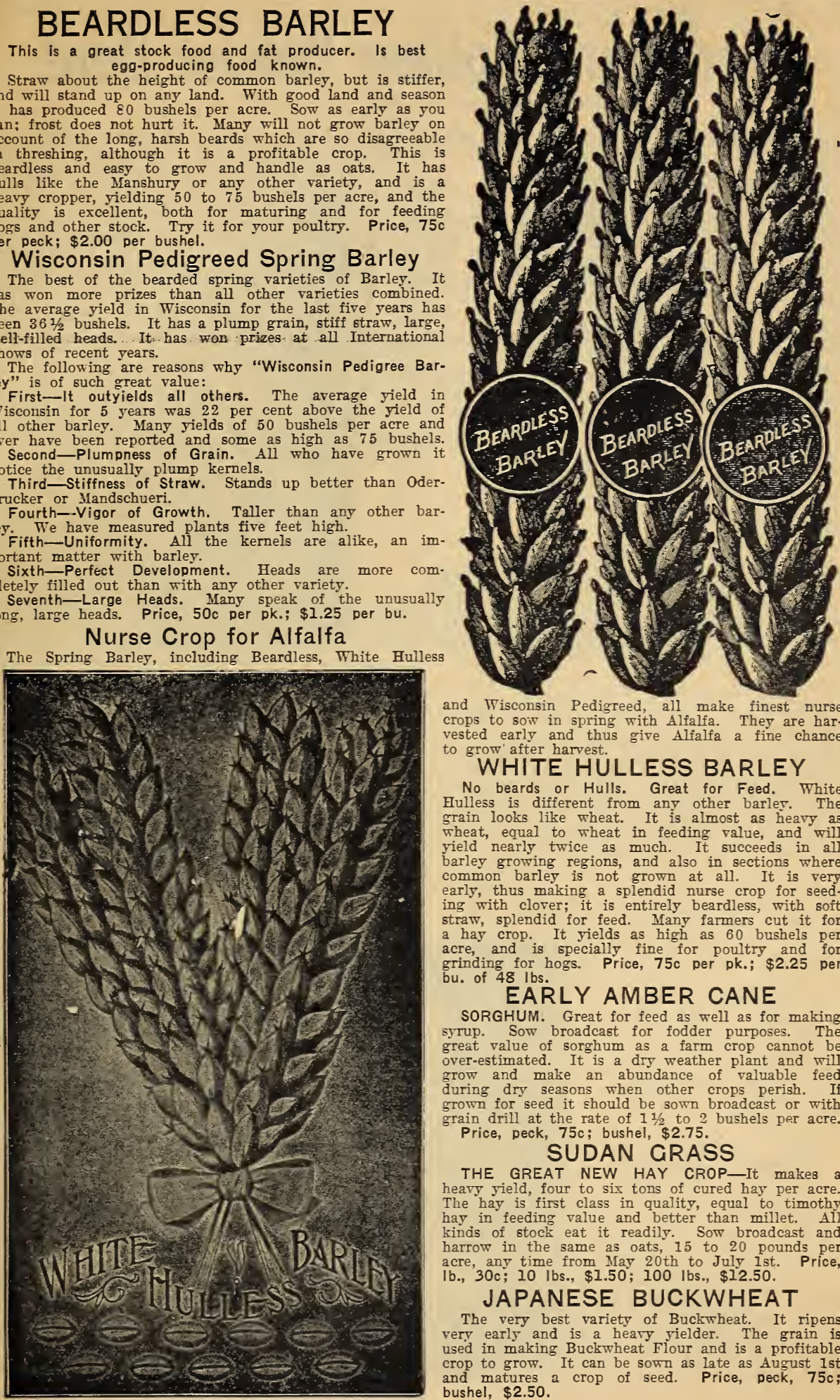

and Wisconsin Pedigreed, all make finest nurse crops to sow in spring with Alfalfa. They are harearly and th

WHITE HULLESS BARLEY

No beards or Hulls. Great for Feed. White Hulless is different from any other barley. The grain looks like wheat. It is almost as heavy as wheat, equal to wheat in feeding value, and will yield nearly twice as much. It succeeds in all barley growing regions, and also in sections where common barley is not grown at all. It is very early, thus making a splendid nurse crop for seed. ing with clover; it is entirely beardless, with soft straw, splendid for feed. Many farmers cut it for a hay crop. It yields as high as 60 bushels per acre, and is specially fine for poultry and for grinding for hogs. Price, $75 \mathrm{c}$ per pk.; $\$ 2.25$ per bu. of 48 lbs.

\section{EARLY AMBER CANE}

SORGHUM. Great for feed as well as for making syrup. Sow broadcast for fodder purposes. The over-estimated. It is a dry weather plant and will grow and make an abundance of valuable feed during dry seasons when other crops perish. If grown for seed it should be sown broadcast or with rain drill at the rate of 11 to 2 bushels per acre.

Price, peck, $75 \mathrm{c}$; bushel, $\$ 2.75$.

\section{SUDAN GRASS}

THE GREAT NEW HAY CROP-It makes a heavy yield, four to six tons of cured hay per acre. The hay is first class in quality, equal to timothy hay in feeding value and better than millet. All harrow in the same as oats, 15 to 20 pounds per acre, any time from May 20th to July 1st. Price, lb., 30 c; 10 lbs., $\$ 1.50$; 100 lbs., $\$ 12.50$.

\section{JAPANESE BUCKWHEAT}

The very best variety of Buckwheat. It ripens very early and is a heavy yielder. The grain is used in making Buckwheat Flour and is a profitable crop to grow. It can be sown as late as August 1st and matures a crop of seed. Price, peck, $75 \mathrm{c}$; bushel, $\$ 2.50$. 


\section{Woodburn Golden Yellow Dent}

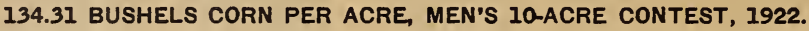

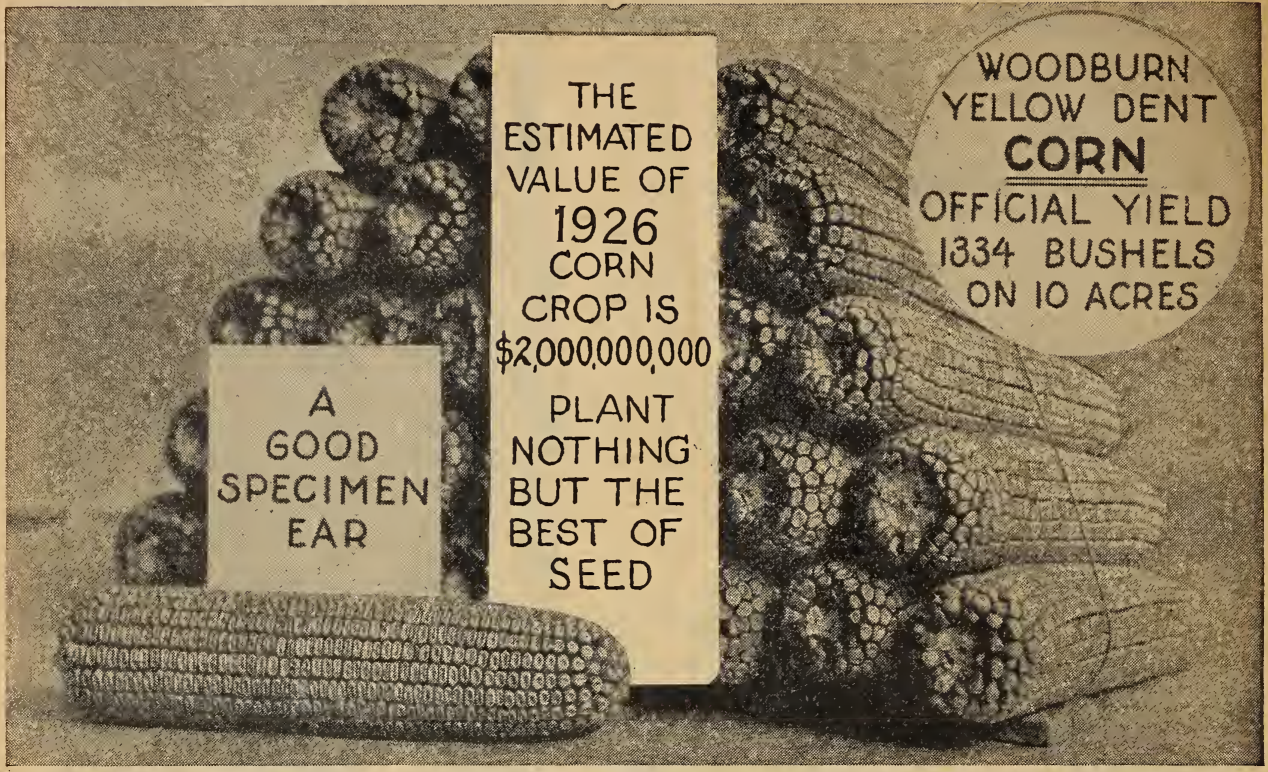

This crop was grown by Mr. Gilmore, Licking County, Ohio. This is the highest yield on record reported in these contests. It was planted four grains in each hill and 33 inches by 36 inches apart. It was grown on clover sod with plenty of fertilizer and manure. This is, perhaps, the highest yield of corn ever grown on ten acres with 20 per cent moisture basis. This variety has become a general favorite wherever planted. We secured our seed stock direct from Mr. Woodburn soon after it was introduced and we have a very fine lot of well-selected seed. If you wish to get a start of this very valuable variety we will be glad to have your order while our supply lasts. A deep-grain, yellow variety of merit. It originated in Champaign County, Ohio and it has figured prominently in many County and State Corn Shows, scoring in points of ear perfections as well as for high yields. It ripens about same season as Leaming. Ears large, well filled with deep grains.

The Woodburn Corn is on every show table and has taken many prizes, besides it is wonderfully prolific, making some high records in Central Ohio. It is used largely by Boys' Corn Clubs and 10-2cre plots. One field planted to this variety will be a good investment. Price $\$ 1.25$ per pk.; $\$ 4.00$ per bu.

\section{YELLOW CLARAGE}

A general favorite all over Ohio where it is establishing itself as one of the best all around varieties we can grow. It is early and grows medium size fodder. The ears are cylindrical, well filled with plump comnact grains. Every ear produced is a solid one. No better variety for farmers everywhere. It is one of the favorite varieties of the Ohio Experiment Station.

Our stock is pure and from prize winning strains.

Many are using and winning with this variety in acre and ten acre contests. You should try a small amount of this variety. Price, per peck, $\$ 1.25$; per bushel, $\$ 4.00$.

\section{Blue Clarage}

Sometimes called Rotten Clarage. Heavy yielder of good solid ears. Matures early. This variety has been a general favorite in many sections and is preferred by many stock feeders. If you have not grown this variety it will pay you to give it a fair trial at least. We have an exceptionally heavy yielding strain. Price, $\$ 1.25$ per peck; $\$ 4.00$ per bushel.

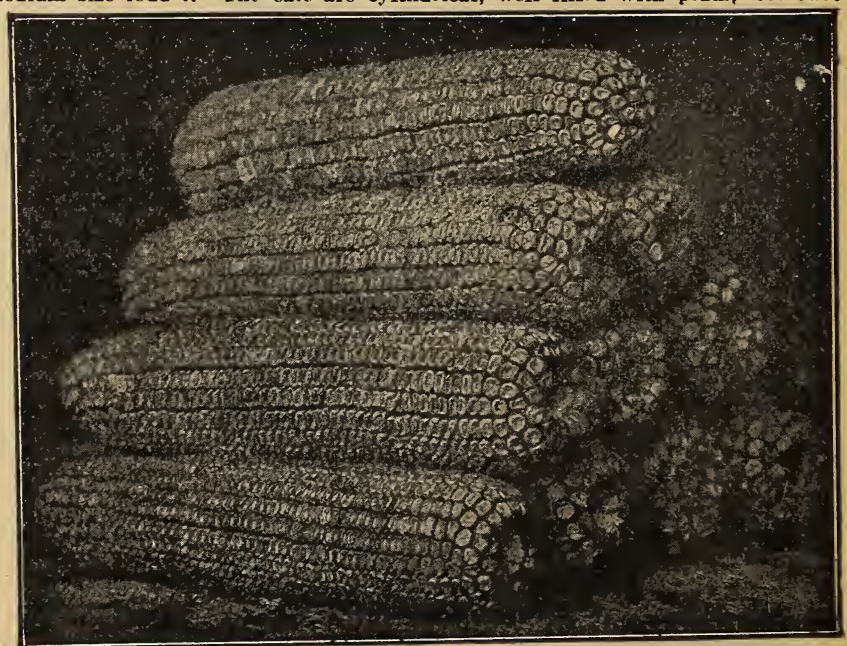

Clarage 
WU 12 WE ARE FEEDING CASH CORN TO 300

We are annually feeding on our farms 300 to 350 head of stock cattle, and we can almost see them put on flesh when feeding Cash Corn. The cob is so small that they eat it greedily, and it is not necessary to shell or cut the ears for them. Our elevators and cattle feeders will pay 5 cents per bushel more for Cash Corn than for the ordinary corn that is generally grown by farmers.

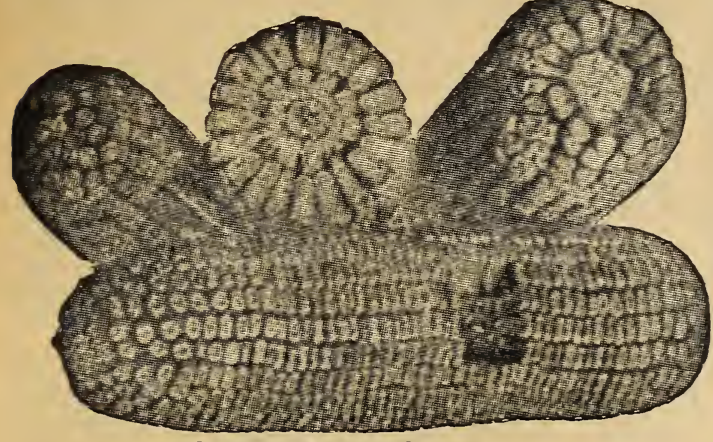

Specimen Ears of Cash Corn. Note Deep Grain and Small Cob. WIII Mature In
95 to 100 Days.

62 pounds of shelled corn per bushel, 70 pounds of ears-only 8 pounds of cobs.

\section{IT'S ALL CORN}

Early to mature and a yielder of finest ears. Matures any place in the United States. It is a new, deep grained, yellow corn, with the smallest cob of any yellow variety known. The ear is large, well filled at butt and tip ends, with beautifully formed deep grains. This corn is beyond doubt the best feeding corn in existence. Matures in about 100 days. Shells easily as early as September. It certainly is the ideal corn. Everyone who sees it will buy it for seed.

It is with a great deal of pride and satisfaction that we offer this valuable corn to our customers. We have grown it on our farms for about ten years, and by careful selection we have it as near perfect as any corn we have ever tried. In fact, everyone who sees it at once recognizes it as the ideal corn. Your money back if the seed

We perhaps sell more Cash Seed Corn than all other varieties combined. It is not a show corn as it varies in color and sometimes shape of ears, but always retains the deep grains and small cob. Of all our customers to whom we have sold Cash Corn we have never had a single objection to it. It is praised. by

As a special favor we ask you to try one field of this corn for your own feeding. It will surprise you how much corn it will yield and the excellent quality. Price, $\$ 1.00$ per pk.; $\$ 4.00$ per bu. Sample ear, $25 \mathrm{c}$,
postpaid. Per quart, postpaid, 50c.

\section{Reid's Yellow Dent} OUR PRIZE-WINNING STRAIN

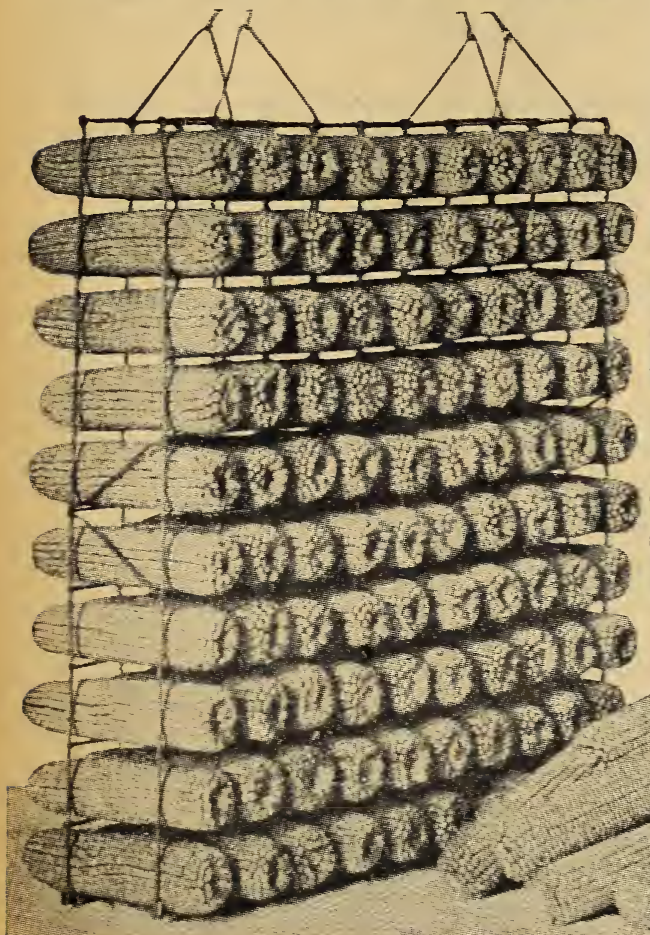

This variety has won more prizes than all other yel. low varieties combined. It is bred to win. If you are interested in high-bred corn of prize winning strain, plant Reid's Yellow Dent.

Our Prize Winning Strain of Reid's Yellow Dent holds the same relation to the yellow varieties as Johnson County holds to the white varieties; both are prize winners. In the class of yellow corn, Reid's Yellow Dent always carries away the prizes. It is bred to conform with the score card better than any other yellow va. riety, and makes an almost perfect ear, fills exceedingly well at both ends of the ear. Grains are well dented and set close together on the cob in very straight and welldefined rows. Our seed stock was procured from the Illinois grower who won the prize in his state for best ten ears Yellow Corn at the 1910 mlinois State Corn Show. We purchased our seed stock direct from him, buying the very best that he could furnish. We have acclimated it here on our Ohio seed farms, and it can be safely planted any place in the corn-growing states. Matures in about 110 days. Our crop of this prizewinning strain of yellow corn is as fine as can be grown, and the seed stock well matured, and carefully selected. Growers will make no mistake in sending us their orders, no matter whether they grow corn for the corn shows or for market, or for feeding purposes. This variety is one of splendid specimen ears. A crib or load of this corn is a fine sight to see, and pleases the grower as well as swells his bank account. A very heary yielder-90 to 100 bushels per acre on good soil. I fine ear, $50 \mathrm{c}$, postpaid; $\$ 1.25$ per peck; $\$ 4.00$ per bushel.

Our strain of Reid's Yellow Dent is the best, and you make no mistake in placing your order with us.

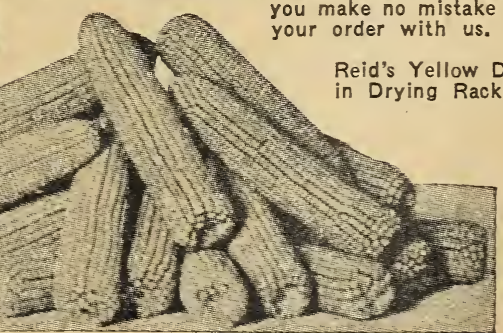



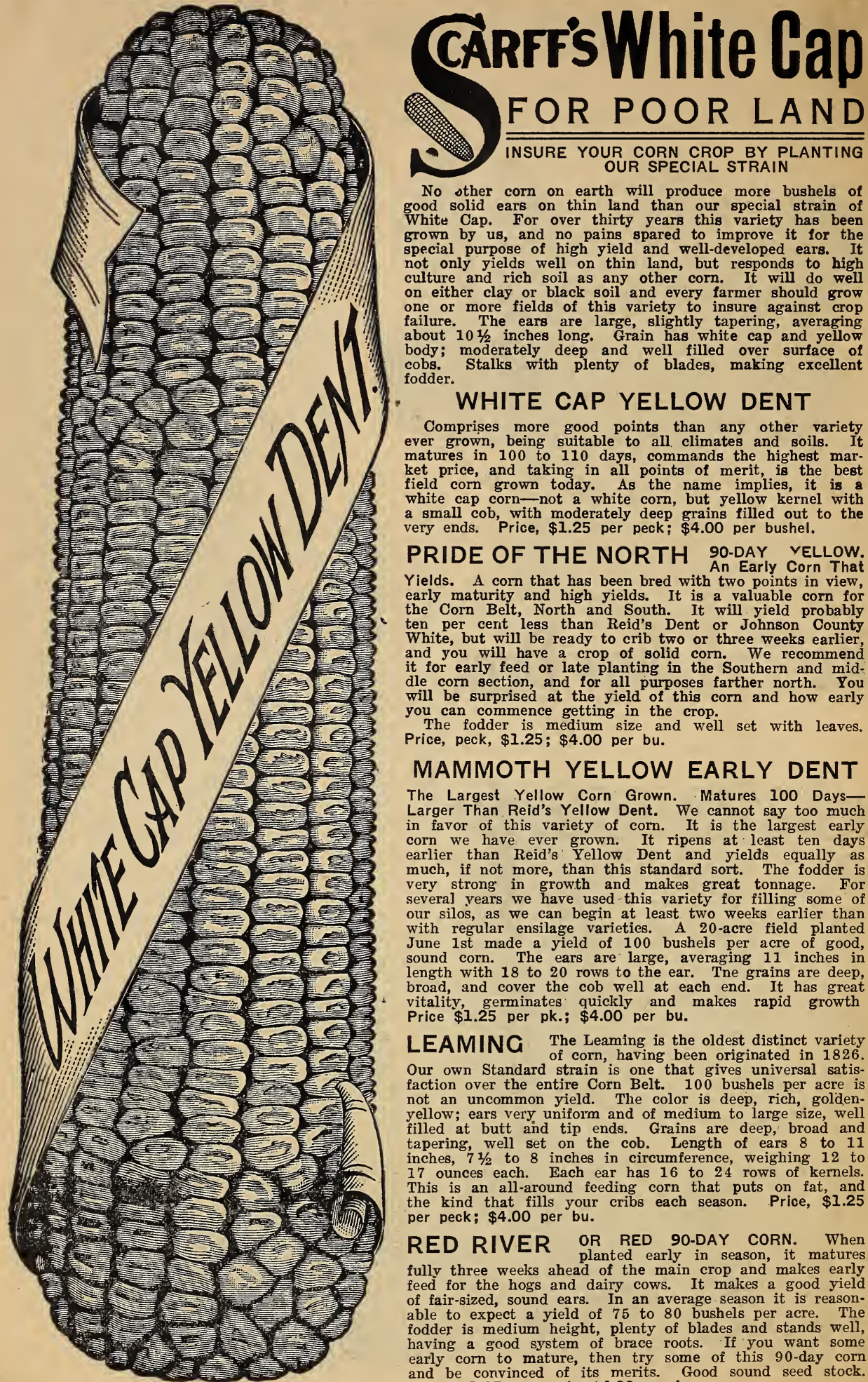

INSURE YOUR CORN CROP BY PLANTING

No sther corn on earth will produce more bushels of good solid ears on thin land than our special strain of White Cap. For over thirty years this variety has been grown by us, and no pains spared to improve it for the special purpose of high yield and well-developed ears. It not only yields well on thin land, but responds to high culture and rich soil as any other corn. It will do well on either clay or black soil and every farmer should grow one or more fields of this variety to insure against crop failure. The ears are large, slightly tapering, averaging about $10 \frac{1 / 2}{1}$ inches long. Grain has white cap and yellow body; moderately deep and well filled over surface of cobs. Stalks with plenty of blades, making excellent fodder.

\section{WHITE CAP YELLOW DENT}

Comprises more good points than any other variety ever grown, being suitable to all climates and soils. It matures in 100 to 110 days, commands the highest market price, and taking in all points of merit, is the best field corn grown today. As the name implies, it is a white cap corn - not a white corn, but yellow kernel with a small cob, with moderately deep grains filled out to the very ends. Price, $\$ 1.25$ per peck; $\$ 4.00$ per bushel.

PRIDE OF THE NORTH 90-DAY VELLOW. PRIDE OF THE NORTH An Early Corn That Yields. A corn that has been bred with two points in view, early maturity and high yields. It is a valuable corn for the Corn Belt, North and South. It will yield probably ten per cent less than Reid's Dent or Johnson County White, but will be ready to crib two or three weeks earlier, and you will have a crop of solid corn. We recommend it for early feed or late planting in the Southern and middle corn section, and for all purposes farther north. You will be surprised at the yield of this corn and how early you can commence getting in the crop.

The fodder is medium size and well set with leaves. Price, peck, $\$ 1.25 ; \$ 4.00$ per bu.

\section{MAMMOTH YELLOW EARLY DENT}

The Largest Yellow Corn Grown. Matures 100 DaysLarger Than Reid's Yellow Dent. We cannot say too much in favor of this variety of corn. It is the largest early corn we have ever grown. It ripens at least ten days earlier than Reid's 'Yellow Dent and yields equally as much, if not more, than this standard sort. The fodder is very strong in growth and makes great tonnage. For several vears we have used this variety for filling some of our silos, as we can begin at least two weeks earlier than with regular ensilage varieties. A 20-acre field planted June 1st made a yield of 100 bushels per acre of good, sound corn. The ears are large, averaging 11 inches in length with 18 to 20 rows to the ear. Tne grains are deep, broad, and cover the cob well at each end. It has great vitality, germinates quickly and makes rapid growth Price $\$ 1.25$ per pk.; $\$ 4.00$ per bu.

LEAMING The Leaming is the oldest distinct variety own Standard strain is one that gives universal satisfaction over the entire Corn Belt. 100 bushels per acre is not an uncommon yield. The color is deep, rich, goldenyellow; ears very uniform and of medium to large size, well filled at butt and tip ends. Grains are deep, broad and tapering, well set on the cob. Length of ears 8 to 11 inches, $71 / 2$ to 8 inches in circumference, weighing 12 to 17 ounces each. Each ear has 16 to 24 rows of kernels. This is an all-around feeding corn that puts on fat, and the kind that fills your cribs each season. Price, $\$ 1.25$ per peck; $\$ 4.00$ per bu.

RED RIVER OR RED 90-DAY CORN. When RLD planted early in season, it matures fully three weeks ahead of the main crop and makes early feed for the hogs and dairy cows. It makes a good yield of fair-sized, sound ears. In an average season it is reasonable to expect a yield of 75 to 80 bushels per acre. The fodder is medium height, plenty of blades and stands well, having a good system of brace roots. If you want some early corn to mature, then try some of this 90 -day corn and be convinced of its merits. Good sound seed stock. Price, $\$ 1.25$ per peck; $\$ 4.00$ per bu. 


\section{W. N. SCARFF \& SONS, NEW CARLISLE, OHIO The Place to Buy Good Seeds}
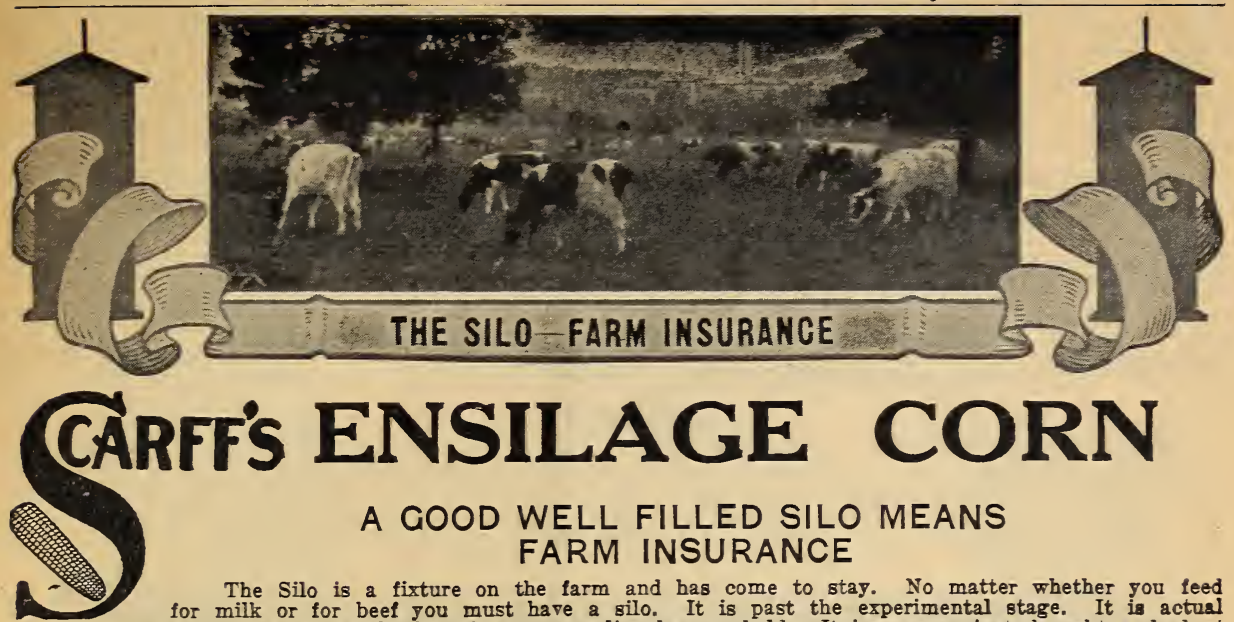

\section{A GOOD WELL FILLED SILO MEANS FARM INSURANCE}

The Silo is a fixture on the farm and has come to stay. No matter whether you feed for milk or for beef you must have a silo. It is past the experimental stage. It is actual insurance for the farmer and is the best insurance policy be can hold. It insures against drought and short pasture in the latter part of the season and if your pasture burns up a well-filled silo will keep up the mill supply equal to the finest grass and put on pounds of beef equally as well.

The next important thing to consider is, "the best ensilage corn to fill the silo." You want first to plant a variet of corn that will make a great tonnage. You want also to plant a variety that will ripen sufficiently to make good ensilage with plenty of body to it. You also want a variety that furnishes an abundance of grain so it is rich and will put on pounds if needed for that purpose or both the dairy cow in good flesh and at the same time keep up a good flow of milk. We have selected a number of varieties that will give splendid satisfaction.

\section{CONNERS PROLIFIC ENSILAGE CORN}

\section{YIELDS TWO TO SIX EARS ON EACH STALK}

The wonderful new variety of eorn that has startled the corn growing people throughout the entire Corn Belt, 150 bushels per acre being no uncommon yield. Investigated and endorsed by the Agricultural press.

DESCRIPTION. The color of the grain is white, the average length of the ears is $81 / 2$ inches, and each stalk bears from 2 to 6 ears. The stalks range in height from 12 to 14 feet, according to season and fertility of the soil.

YIELD. The seed from which our stock is being sold yielded 150 bushels of corn to the acre, and ao fertilizer of any kind was applied to the land.

In every test the yield of the new variety has been at least twice that of the old standard varieties of the Corn Belt. There is no reason why the yield will not reach 200 bushels per acre prith proper development. Six ears to the stalk are not uncommon, and only in a few cases will it yield less than two to the stalk. Three and four ears is the general run.

A WONDERFUL CORN FOR THE SILO. Beyond doubt this is the best ensilage corn that can be planted if rich ensilage is desired, as there are so many ears on each stalk. Also a great tonnage.

PRICE OF CONNERS CORN. Sample packets, 15c; quart, $60 \mathrm{c}$, parcel post, prepaid. By frelght or express, not prepaid, peck, $\$ 1.50$; bushel, $\$ 4.00$. Shelled only.

\section{EUREKA ENSILAGE}

This is a favorite ensilage corn with many growers, as it produces an extra large tonnage, as much as 20 tons per acre. The stalks are large, with plenty of blades, and a good proportion of grain. Many stalks produce two sized ears. Price, peck, $\$ 1.50 ; \$ 5.00$ per bushel.

\section{JOHNSON COUNTY WHITE}

THE GREATEST SHOW CORN IN THE WORLD. This variety has taken more prizes than all other varieties combined. This is the corn for which we paid $\$ 350.00$ for 10 ears at the National Corn Show, at Columbus, Ohio. A single ear of this variety has won $\$ 1,000.00$ in prizes; and during the National Corn Shows at Chicago, Omaha, and Columbus, this variety has won approximately $\$ 15,000.00$ in prizes. It has been bred for \& long term of years by the most careful corn breeders and has fired a type of corn that conforms so closely to score card that few others have much chance of being winners. It breeds true to type, 0 that Show Corn is the rule rather than the exception. To tkose wishing to compete for prizes at the fairs ind corn shows we would strongly advise

planting this variety.

OVER 100 BUSHELS PER ACRE

The Johnson County White Corn you sent me grew ears measuring 10 inches long. I have some good corn of my own. but I can say the Johnson County White is the best $I$ ever $82 w$, etc. RUFUS H. HARRISON, Maryland.

The ears are cylindrical in shape, slightly tapering at the end, well filled out at both butt and tip ends, straight rows with grains close together. Corn pure white and cob came color. The ears run from 10 to 11 inches in length and about 8 inches in

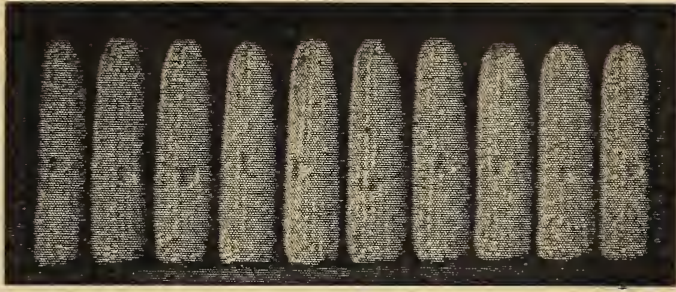

Ten Ears of Prize Winning Johnson County White. These Ten Ears Cost Us $\$ 350.00$.

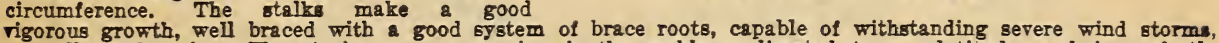
is well as drought. The strain pe are growing is thoroughly acclimated to our latitude, and is perfectly wafe to plant in all corn growing sections except the extreme North, where only very early sorts can be grown. The ears are very uniform and large size, with deep grains, and will yield 100 to 135 bushels per acre. It is - variety very rich in protein, hence valuable for feeding purposes, also valuable for silo, as it makes as much fodder as the regular ensilage corn and so much larger proportion of ears, bence a much richer ensilage.

Price, $\$ 1.25$ per peck; $\$ 4.00$ per bushel. 


\section{0 Bred Fall and Spring Hampshire Gilts

\section{For Private Sale at Attractive Prices}

This fine lot of gilts are by Quality Pershing 103419, Brass Tax 103053, and White Oaks Roller 126177. A more even lot of more wonderful type and quality throughout is hard to find anywhere you may go. The spring gilts will weigh 150 to 200 and the fall gilts from 200 to 300 pounds, just in fine breeding condition. They are bred to farrow from March to June. The blood lines they carry are equal to any. The prices quoted below are very conservative for this quality of stock and we will do our very best to make a selection for you as near your description and desires as we possibly can.

\section{FALL GILTS BRED - $\quad$ - $\$ 60.00 \quad$ SPRING GILTS BRED $\quad$ - $\$ 50.00$}

IMMUNITY Every animal on our farms is treated for Cholera by the use of simultaneous method with the best serum and virus obtainable.

\section{GUARANTEE}

Every hog which we sell is guaranteed to be a breeder; any animal wbich is not a breeder is reduced to pork prices, just as soon as such non-breeding shall have been established satisfactory in our judgment.

Any sow not safely settled, if notified within 30 days from date received, 20 per cent of the purchase price will be refunded, or sow may be returned to our farm and bred to one of our herd boars free.

We have on hand at all times stock of all ages and we will be glad to describe fully if you will tell us the age you need.

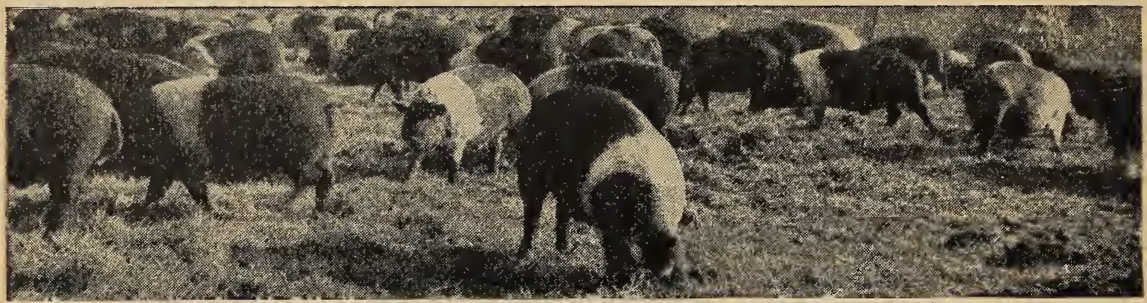

The Hampshire Hog, on pasture or behind cattle, has no equal. They put on the most economical gains and are always working. Good mothers. Big litters. Real moneymakers. A few good sows well cared for will lift the mortgage or buy a new car.

Write for our Special Live Stock Circular.

\section{HAMPSHIRE DOWN SHEEP}

Our flock consists of One Hundred registered Hampshire Ewes. We purchased our foundation stock from the Walnut Hall Farms, Donerail, Ky., where the best individuals and most noted blood lines have been mated and some of the best individuals of the Hampshire breed produced. Many of their Rams were imported and the Walnut Hall Farms are known everywhere for the quality of stock they produce. We personally visited the farm, selected 50 Ewes from their entire flock which constitutes our foundation stock. The lambs produced by them this spring have those same good qualities and are exceptionally fine individuals. Yearling Rams, $\$ 35.00$; Bred Ewes, $\$ 20.00-\$ 40.00$; 1926 Ewe or Buck Lambs, $\$ 25.00$ each.

\section{AYRSHIRE DAIRY CATTLE}

We are just beginning to realize the value of the Ayrshire as an ideal dairy cow. Our herd has been established four years and each season we are more firm in the belief that she carries more quality that made her desirable and profitable for the general farmer or family than any other herd of daiy cattle. We have put them under only ordinary conditions and they have paid a profit on the investment. They will do the same for you. We have established our herd upon very popular and heavy producing blood lines and the individuals we have are good ones. We are offering some young stock now and are sure our Ayrshires will please you. Calves 3 months old, $\$ 50.00$ each; Yearling heifers, $\$ 100.00$ each; Bred heifers. $\$ 125.00$ each,

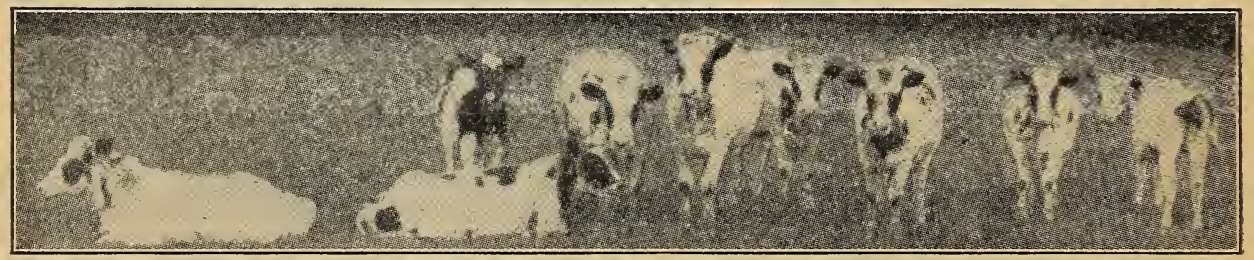

\section{AYRSHIRES AND THEIR MILK}

To anyone who has given the matter study, Ayrshire milk has proven itself the most perfect food for infant and invalid, and the most satisfactory of dairy products for general domestic purposes, due to the fact that the 4 per cent of fat gives the milk a proper balance, sufficient but not too heavy, and the greater amount of solids providing more nourishment, together with the fact that the molecules of fat in the milk are much smaller than in milk of the other breeds accounts for its being much more easily digested. Send for special Ayrshire Catalog. 


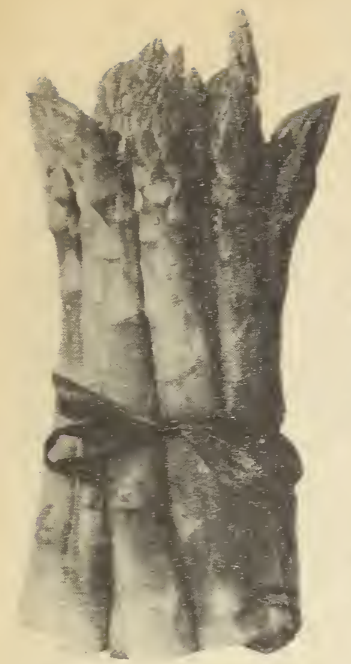

\section{The New Washington Asparagus COLORED LEAFLET ON ASPARAGUS CULTURE FREE}

This new variety of Asparagus is practically rust proof and has been developed by the Bureau of Plant Industry, Washington, D. C., in co-operation with the Massachusetts Agricultural Experiment Station, and other careful growers throughout the country. It is now being offered for sale to the public and it is thought that it will gain general favor wherever it is planted. Our seed was procured from a reliable source and is strictly true to name. Washington is a vigorous high yielding strain of Giant Asparagus and a most profitable crop to grow for market. As a variety for the home garden it has no equal. No other vegetable can take the place of Asparagus. It is ready to cut for the table so early in season and continues over a long period of time. It is nutritious and healthy being rich in vitamines so essential to good health. If you already grow Asparagus then add this new and wonderful variety to your collection. If you do not have a bed of it growing then do not let another year go by without planting. We are offering the roots very low so all may get a start at once. Price, 75 cents per dozen, postpaid; $\$ 2.50$ per $100 ; \$ 20.00$ per 1,000 .

\section{Mary Washington}

This is a strain selected from the Washington variety. It produces a much heavier stalk and the canes are more numerous than the original Washington variety. Like its parent it is practically rust resistant. Mary Washington will make you the most money as a market variety. We can supply a limited amount of this stock from reselected pedigreed seed at $75 \mathrm{c}$ per doz.; $\$ 3.00$ per $100 ; \$ 25.00$ New Washington Asparagus per 1,000.

\section{Columbian Mammoth White}

A distinct variety of mammoth size, great yield, and superior quality; remarkable for the clear whiteness of its stalks, which retain their purity and color until several inches above the surface. Price, 75 cents per dozen, postpaid; $\$ 2.00$ per 100 ; $\$ 12.00$ per 1,000 by express or freight.

\section{Other Varieties}

GIANT ARGENTEUIL, PALMETTO, CONOVER'S COLOSSALAND BARR'S MAMMOTH. The standard market sorts, all green and tender. Price, 75 cents per dozen, postpaid; $\$ 2.00$ per $100 ; \$ 12.00$ per 1,000 ; by express or freight.

\section{CHOICE RHUBARB \\ COLOOED LARELT ON RHUQAAB CULTURE F FEE}

People are just beginning to realize the great profit in the culture of Rhubarb in the open field, also as a forcing crop for. Winter. It yields enormous profits. Anyone can succeed, as the culture is very simple.

\section{Linnaeus}

Large, early, tender and fine. The very best of all. 20 cents each; $\$ 2.00$ per dozen, postpaid; $\$ 8.00$ per 100 .

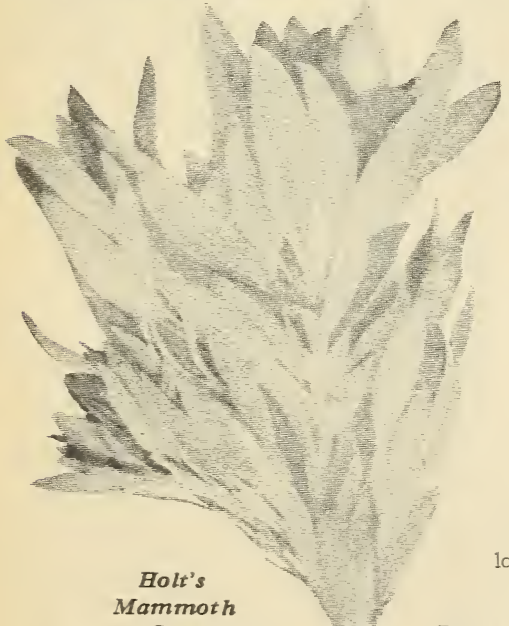

\section{Queen}

Strong, vignrous grower producing extra laige stalks of finest quality-of a decided pink color. For canning or cooking in any way its quality is unsurroots, 20 cents each

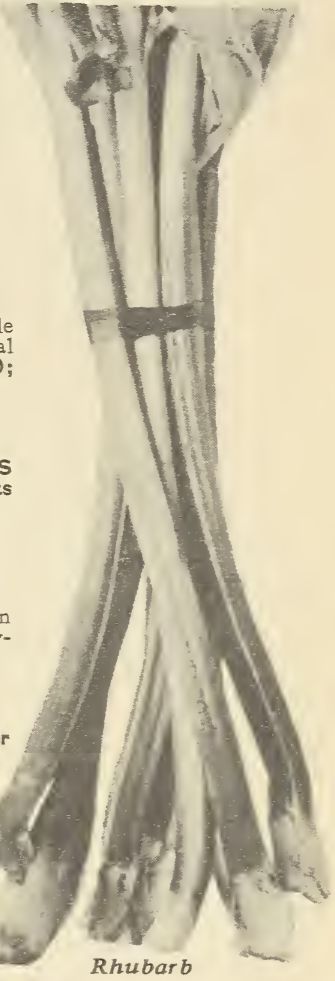

$\$ 20.00$ per dozen, postpaid; $\$ 8.00$ per 100 .

\section{Maliner Kren Horseradish}

This new variety makes an enormous yield and is so early that it can be marketed before the common kind is ready; besides the roots are much larger and whiter. The roots sell in market at 5 to 10 cents per pound, and yield as high as 8,000 pounds per acre. It requires about 10,000 sets for an acre, and the crop is ready for the market the first year. It is easy to grow; every plant will live. Net profit, $\$ 300.00$ to $\$ 600.00$ per acre. Try at least 1,000 sets if you cannot plant an acre. It is ready sale in any of the large cities. Price of good roots, 75 cents per dozen, postpaid; $\$ 2.00$ per $100 ; \$ 15.00$ per 1,000

\section{Common Horseradish}

This useful condiment is easily grown, and prefers a rich, moist oam. Price, 50 cents per dozen; $\$ 1.50$ per $100 ; \$ 12.00$ per 1,000 .

\section{HOLT'S MAMMOTH SAGE}

Plants of strong growth, of unusual substance, strong flavor and of superior quality. Prefers a rich, moist loam. Price, 10 cents each, $\$ 1.00$ per doz., postpaid. Large clumps by express, not prepaid, same price. 


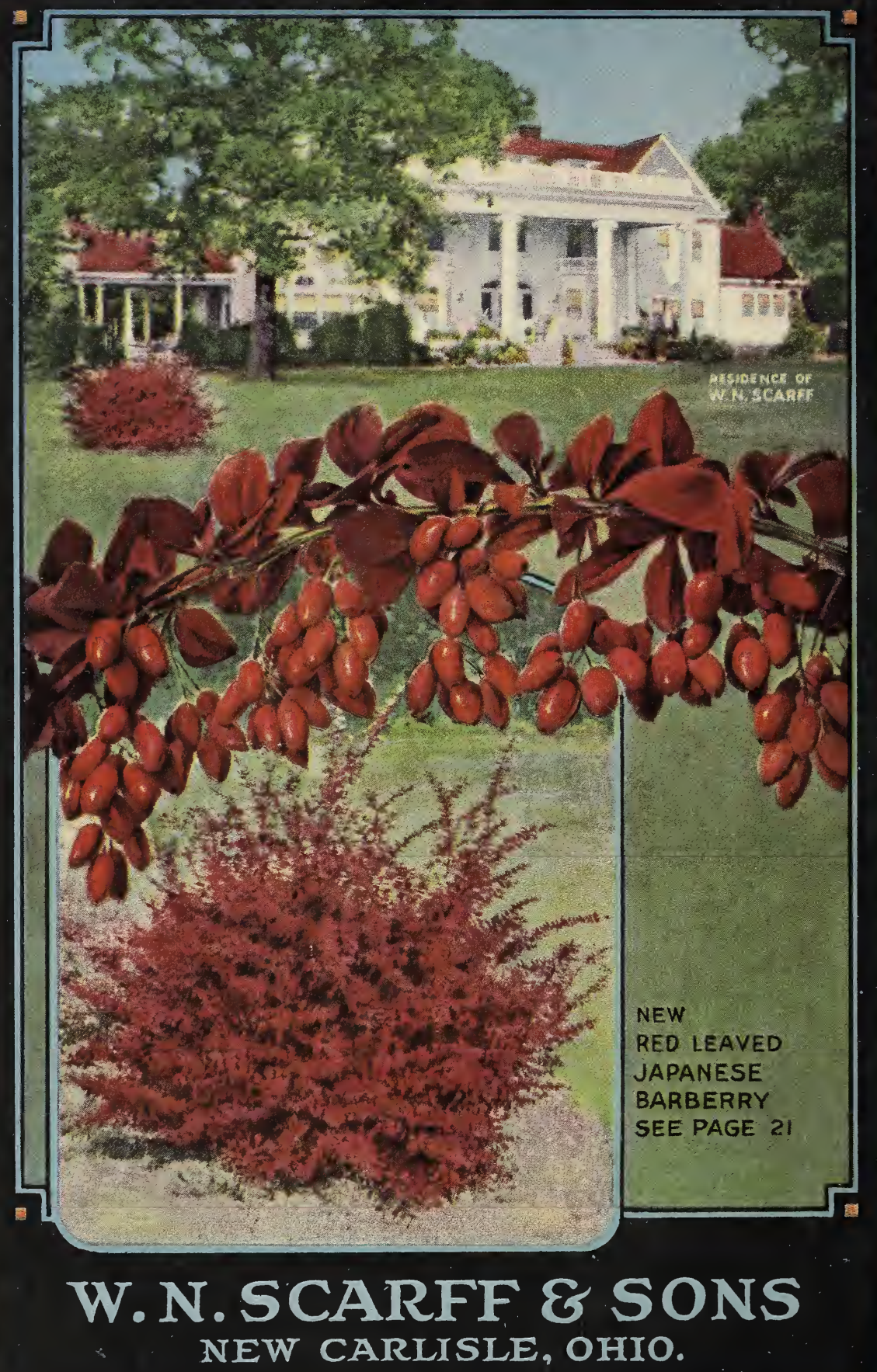

